\title{
AVALIAÇÃO DO APROVEITAMENTO AGRÍCOLA DE LODOS DE CURTUME
}

\author{
VICENTE DE AQUINO NETO \\ Engenheiro Agrônomo
}

\section{Orientador: Dr. OTÁVIO ANTÔNIO DE CAMARGO}

\author{
Dissertação apresentada à Escola Superior de \\ Agricultura "Luiz de Queiroz", Universidade de \\ São Paulo, para obtenção do título de Mestre em \\ Agronomia, Área de Concentração: \\ Solos e Nutrição de Plantas.
}

P I R A C I C A B A

Estado de São Paulo

Janeiro - 1998 
Dados Internacionais de Catalogação na Publicação (CIP) DIVISÃO DE BIBLIOTECA E DOCUMENTAÇÃO - Campus "Luiz de Queiroz"/USP

Aquino Neto, Vicente de

Avaliação do aproveitamento agricola de lodos de curtume / Vicente de Aquino Neto. - - Piracicaba, 1998.

$111 \mathrm{p}$.

Dissertaçāo (mestrado) - - Escola Superior de Agricultura Luiz de Queiroz, 1998.

Bibliografia.

1. Alface 2. Cromo 3. Fitotossanidade 4. Latossolo 5. Lodo de curtume 6. Metal pesado 7. Quimica do solo 8. Resíduo industrial I. Título

CDD 631.41 


\title{
AVALIAÇÃO DO APROVEITAMENTO AGRÍCOLA DE LODOS DE CURTUME
}

\author{
VICENTE DE AQUINO NETO
}

Aprovada em: 18.02.1998

Comissão julgadora:

Prof. Dr. Márcio Rodrigues Lambais

ESALQ/USP

Prof. Dr. Wanderley José de Melo

FCAVJ/UNESP

Dr. Otávio Antônio de Camargo

IAC

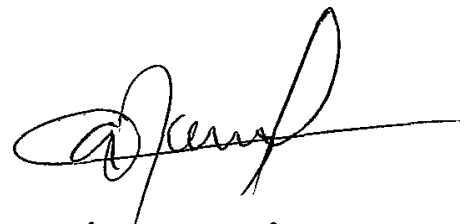

Dr. OTÁVIO ANTÔNIO DE CAMARGO

Orientador 
Para a Denise e a Mona 


\section{AGRADECIMENTOS}

Ao Dr. Otávio Antônio de Camargo, pela confiança, orientação e exemplo de conduta ética.

Aos Drs. Heitor Cantarella, João Carlos de Andrade, Ronaldo S. Berton e Marino José Tedesco, pelas valiosas sugestões apresentadas.

À CETESB, Companhia de Tecnologia de Saneamento Ambiental, por possibilitar a realização desta pesquisa.

Aos amigos da CETESB: Paulo Henrique "Biga", pela imprescindível ajuda nos trabalhos experimentais;

Rodrigo, por tornar viável a oportunidade de participação no curso de mestrado.

Nádia e o Sandro, pela ajuda nas análises químicas.

Maria José, por realizar a edição final da dissertação.

Gunther pelo apoio ao projeto.

Aos amigos do IAC, "Seu” José, Mônica, Jussara e Pedro Furlani pela colaboração e acolhida.

Ao curtume Podboi e em especial ao técnico José Luiz pelo auxílio na obtenção dos resíduos. 


\section{SUMÁRIO}

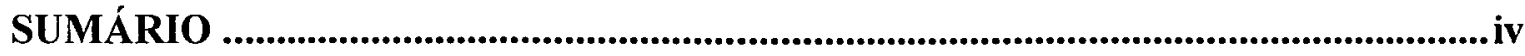

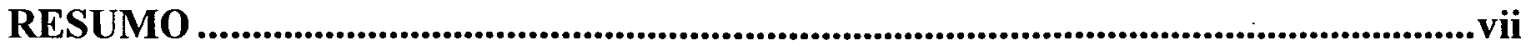

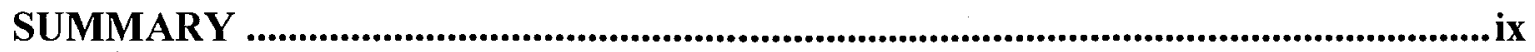

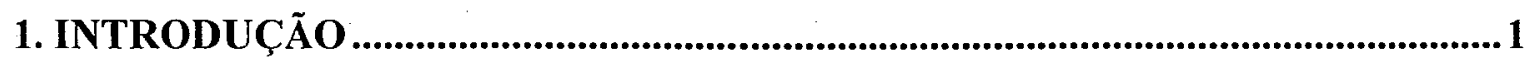

2. REVISÃO DE LITERATURA

2.10 processo industrial de curtimento do couro ................................................................4

2.1.1 Conservação da pele................................................................................................

2.1.2 Operações de ribeira ...........................................................................................................5

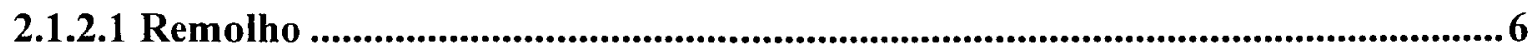

2.1.2.2 Depilação e caleiro............................................................................................................... 6

2.1.2.3 Descarne e divisão …............................................................................................

2.1.2.4 Descalcinação e purga .....................................................................................................

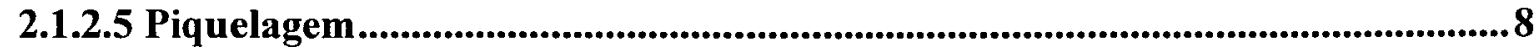

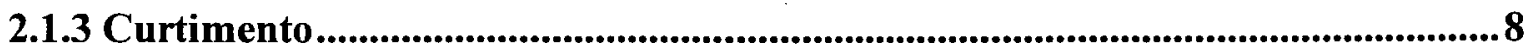




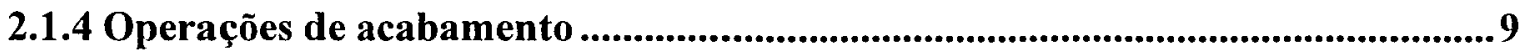

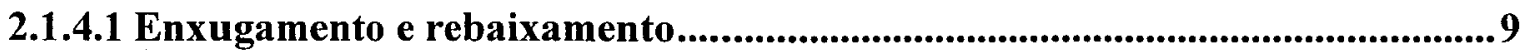

2.1.4.2 Neutralização

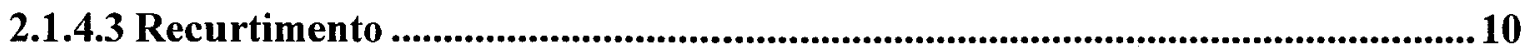

2.1.4.4 Tingimento .............................................................................................................................. 10

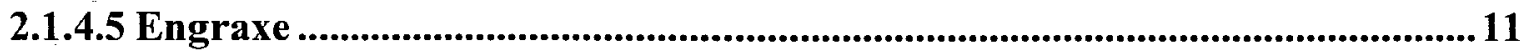

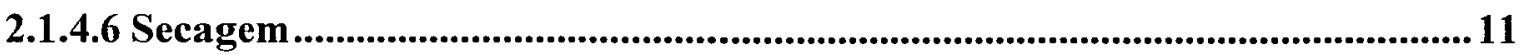

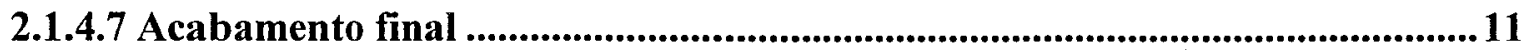

2.1.2 Geração de efluentes e resíduos sólidos...................................................................12

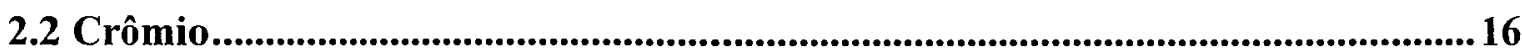

2.2.1 O crômio nos seres vivos........................................................................................17

2.2.1.1 O crômio no homem e nos animais......................................................................17

2.2.1.2 O crômio nas plantas ......................................................................................... 19

2.2.2 O crômio no solo

2.2.2.1 Crômio III no solo .................................................................................................30

2.2.2.1.1 Precipitação - adsorção ........................................................................................31 


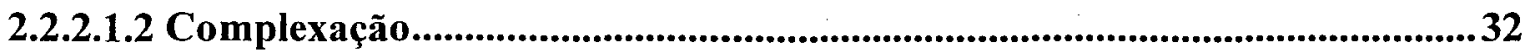

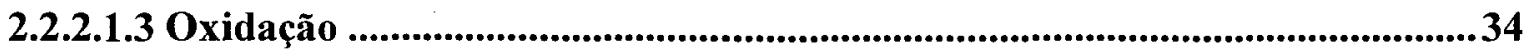

2.2.2.2 Crômio (VI) no solo...........................................................................................38

2.2.2.2.1 Adsorção e precipitação.....................................................................................................38

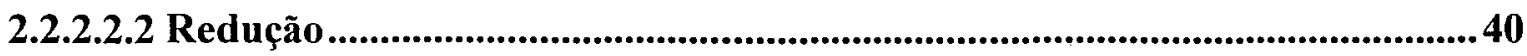

2.3 Nitrogênio...................................................................................................................................42

2.3.1 Mineralização do N-orgânico em resíduos...............................................................43

2.3.2 Efeito do crômio na mineralização do nitrogênio ....................................................46

3. POTENCIAL de MineralizaÇÃo do NITROGÊNIO EM LODOS DE CURTUME ADICIONADOS A DOIS LATOSSOLOS ........................................49

4. DESENVOLVIMENTO E ABSORÇÃO DE CRÔMIO PELA ALFACE CULTIVADA EM DOIS LATOSSOLOS TRATADOS COM CRCL $\mathrm{C}_{3}$ RESÍDUOS DE CURTUME ....................................................................................70

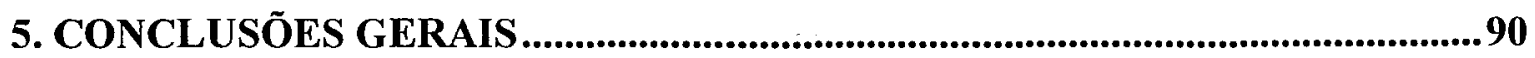

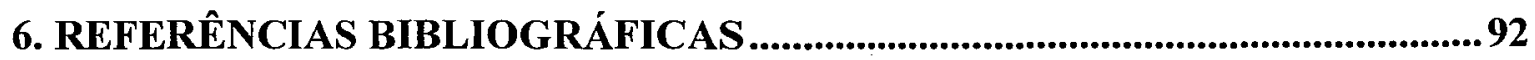




\title{
AVALIAÇÃO DO APROVEITAMENTO AGRÍCOLA DE LODOS DE CURTUME
}

\author{
Autor: Vicente de Aquino Neto \\ Orientador: Dr. Otávio Antônio de Camargo
}

\section{RESUMO}

Devido ao seu elevado teor de nitrogênio e potencial de neutralização da acidez do solo a utilização de lodos de curtume em áreas agrícolas pode ser uma alternativa eficiente no tratamento e reciclagem destes resíduos. Por outro lado, também apresentam uma alta concentração de sódio e crômio, que podem constituir-se em fatores limitantes nesta forma de aproveitamento. Com a finalidade de estudar esta prática foram conduzidos em 1996/97 dois experimentos onde foram utilizados os solos latossolo roxo eutrófico (LRe), unidade Ribeirão Preto e latossolo vermelho amarelo (LVA) - unidade Laranja Azeda e dois lodos gerados no tratamento dos efluentes do curtume Podboi localizado em Leme (SP), o lodo do decantador primário (LCR) contendo $17 \mathrm{mg} . \mathrm{g}^{-1}$ de crômio e o lodo do caleiro (LCL) sem crômio, incorporados aos solos nas doses (base seca) equivalentes a 19, 38 e $57 \mathrm{Mg}^{-h^{-1}}$ (LCR) e 10, 20 e $30 \mathrm{Mg}^{-h^{-1}}$ (LCL). Um dos experimentos foi realizado em laboratório, onde estudou-se o potencial de mineralização do $\mathrm{N}$-orgânico contido nos lodos. As doses utilizadas resultaram em uma aplicação total de nitrogênio de 226, 452 e $678 \mathrm{mg} \cdot \mathrm{kg}^{-1}$ de N para o LVA e 256, 512 e $768 \mathrm{mg} \cdot \mathrm{kg}^{-1}$ de N para o LRe. O estudo foi conduzido em tubos de percolação preenchidos com $40 \mathrm{~g}$ das misturas solo $\mathrm{x}$ lodo que foram periodicamente lixiviadas, determinando-se a concentração de $\mathrm{NH}_{4}{ }^{+}$e $\mathrm{NO}_{3}{ }^{-}$no eluente. Os dados foram analisados assumindo-se uma reação cinética de primeira ordem, modelando-se o nitrogênio mineralizado acumulado 
de acordo com uma equação exponencial simples. O processo de mineralização foi muito afetado pela presença do crômio, observando-se uma mineralização líquida de $35 \%$ para o LCL e 4,8\% para o LCR em média. O modelo utilizado não mostrou um ajuste eficiente para os dados experimentais do tratamento que recebeu lodo com crômio, provavelmente devido à formação de complexos de difícil degradação entre o metal e os compostos orgânico do lodo.

O outro experimento foi conduzido em vasos alocados em casa de vegetação, onde além dos tratamentos com lodo de curtume comentados, foi realizado um tratamento adicional que constou da aplicação de $\mathrm{CrCl}_{3}$ nas doses de 330, 660 e 990 kg.ha ${ }^{-1}$ de $\mathrm{Cr}$, equivalente às doses aplicadas do metal na forma de lodo (LCR). Foram estudados os efeitos destas aplicações no desenvolvimento e acumulação de crômio pela alface. A oxidação do $\mathrm{Cr}$ (III) foi verificada apenas para o LRe nos tratamentos que receberam doses crescentes de $\mathrm{CrCl}_{3}$. A aplicação dos resíduos elevou a condutividade elétrica do extrato de saturação (2:1) (1,40 a 5,07 dS.m $\left.{ }^{-1}\right)$ e a RAS $(3,05$ a 14,12), afetando negativamente o desenvolvimento da alface e causando a morte das plantas nas dosagens mais altas, sendo estes efeitos mais pronunciados no LVA. A concentração de crômio na parte aérea das plantas aumentou, nem sempre de forma proporcional, com o aumento das doses aplicadas na forma de lodo ou sal, com efeito mais acentuado para o LVA do que para o LRe. A aplicação de resíduos de curtume no experimento, para ambos os solos, mostrou-se mais limitada pelo seu conteúdo de sais do que pela presença de crômio. 


\title{
EVALUATION OF THE AGRICULTURAL USE OF TANNERY SLUDGES
}

\author{
Author: Vicente de Aquino Neto \\ Adviser: Dr. Otávio Antônio de Camargo
}

\section{SUMMARY}

Due to the high nitrogen and lime content soil amendment with tannery sludges could be an efficient alternative for the treatment and recycle of this wastes. Otherwise, the high sodium and chromium concentration of this wastes could limit this use. In order to evaluate this two experiments were conducted using the soils Typic Eutrothox (LRe) and Typic Haplorthox (LVA) and two sludges from the effluent treatment plant of the Podboi tannery at Leme (São Paulo - Brasil). The tannery wastes were sludge from the limming process (LCL) without chromium and the primary sludge (LCR) with a total chromium content of $17{\mathrm{mg} . \mathrm{g}^{-1}}^{-1}$ which were incorporated to the soils at the rates of 10,20 and $30 \mathrm{Mg} \cdot \mathrm{ha}^{-1}$ for the LCL and 19,38 and $57 \mathrm{Mg}^{-h^{-1}}$ for the LCR, both at a dry weight basis. The first experiment was laboratory evaluation of the nitrogen mineralization potential of the sludges. The application rates are equivalent to an application of total nitrogen of 226, 452 and $678 \mathrm{mg} \cdot \mathrm{kg}^{-1}$ of $\mathrm{N}$ for the LVA and 256,512 and $768 \mathrm{mg} \cdot \mathrm{kg}^{-1}$ of $\mathrm{N}$ for the LRe. A mixture of soil and sludge were put in glass columns and leached periodically to determine $\mathrm{NH}_{4}{ }^{+}$and $\mathrm{NO}_{3}{ }^{-}$in the leachate. The nitrogen mineralization potential $\left(\mathrm{N}_{0}\right)$ was estimated by a non linear regression statistical method using a simple exponential equation according to a first order kinetics reaction. The mineralization process was strongly influenced by the chromium presence with observed net sludge organic N mineralized values of $35 \%$ for the LCL and $4,8 \%$ for the LCR. The used model doesn't fit very well for the experimental data of the LCR, probably because chromium complexes formed with organic compounds which makes 
degradation more difficult. The second study was a greenhouse pot experiment using the same soils and sludge application rates and including an additional treatment with $\mathrm{CrCl} 3$ applied at rates of 330,660 and $990 \mathrm{~kg} \cdot \mathrm{ha}^{-1}$ of chromium, equivalent to the rates applied of LCR sludge. The application of both sludges increased the eletrical conductivity $(1,40$ a 5,07 dS.m $\left.{ }^{-1}\right)$ and the sodium adsorption rate $(3,05$ a 14,12). It affected lettuce development causing death of the plants at the highest rates. $\mathrm{LCR}$ and $\mathrm{CrCl}_{3}$ treatments increased levels of chromium in the plant tops but not always proportionaly with increasing rates. Both ocurrences were more pronounced for the LVA soil. Under the conditions of the experiment salt content insted chromium content of the sludge limited tannery wastes soil amendments. 


\section{INTRODUÇÃO}

A produção brasileira de couros inteiros curtidos de bovinos em 1992 alcançou a cifra de 22 milhões de peças, sendo que $85 \%$ deste total foi submetida ao curtimento com crômio, num total aproximado de 19 milhões de peças. O Estado de São Paulo possuia nesta ocasião 92 curtumes em operação cadastrados no Guia Brasileiro do Couro elaborado pela Associação Brasileira de Químicos e Técnicos da Indústria do Couro - ABQTIC (1995), com destaque para a região de Franca, que concentra uma grande quantidade deste total (aproximadamente 25\%), visando abastecer o principal centro da indústria de calçados do Estado lá instalado.

Segundo levantamentos realizados pela Companhia de Tecnologia de Saneamento Ambiental - CETESB em curtumes localizados no Estado de São Paulo, no processamento destas peles são gerados resíduos líquidos com grande quantidade de contaminantes químicos, que após seu tratamento geram resíduos sólidos ou semisólidos (lodos), a uma taxa estimada de 5 a 20 toneladas por tonelada de pele processada. (Straus e Silva, 1980).

As características deste lodo variam muito em função do tipo de pele a ser processada, da tecnologia empregada no curtimento e do sistema de tratamento adotado. De uma maneira geral, estes resíduos constituem-se principalmente de materiais orgânicos de origem animal misturados com sais inorgânicos utilizados no processo de curtimento. 
No Estado de São Paulo a destinação final destes lodos é feita, predominantemente, pela sua disposição no solo de forma não controlada, geralmente em locais inadequados para recebê-los, seja em solos agrícolas ou áreas de sacrifício.

Atualmente é inquestionável o fato de que os resíduos provenientes dos diferentes processos industriais devam sofrer tratamentos que proporcionem a degradação, transformação e/ou imobilização dos constituintes que compõe o resíduo e que possam comprometer a qualidade ambiental, colocar em risco a saúde ou gerar desconforto à população. Neste contexto, a utilização do solo com esta finalidade é bastante recomendável, haja visto os mecanismos intrínsecos à sua organização, baseados em uma perfeita interação da atividade biológica e propriedades físicoquímicas.

Devido ao elevado teor de nitrogênio normalmente observado nestes resíduos, este elemento é freqüentemente o fator que determina a quantidade de lodo que pode ser aplicada ao solo. Neste sentido, deve ser observado que o N-orgânico contido no lodo não é prontamente disponível para as plantas, requerendo-se um conhecimento prévio da dinâmica do seu comportamento após a aplicação do lodo no solo. Outra característica favorável do aproveitamento agrícola destes resíduos vem a ser o elevado potencial de neutralização da acidez do solo conferido pelos teores de cálcio-carbonato normalmente encontrados.

Por outro lado, os teores elevados de sódio e crômio presentes no resíduo podem constituir-se em fatores limitantes para a sua aplicação no solo. O primeiro pode causar uma elevação da condutividade elétrica da solução do solo e seu acúmulo a dispersão das partículas de argila. O crômio presente no resíduo encontra-se presente na forma trivalente, considerada essencial à nutrição humana e possuindo pouca mobilidade no solo, entretanto, este elemento possui uma complexa dinâmica no solo e em determinadas condições pode oxidar-se à forma hexavalente, muito móvel no solo e tóxica à plantas, animais e seres humanos.

O trabalho em questão teve por objetivo estudar o efeito da aplicação no solo de lodos gerados em estação de tratamento de efluentes de curtume sobre: a) o 
desenvolvimento da alface e o acúmulo de crômio no tecido vegetal desta cultura; b) as alterações nas propriedades químicas do solo causadas pela grande concentração de sais do resíduo; c) a dinâmica de oxidação do crômio trivalente no solo; d) a dinâmica de mineralização do nitrogênio orgânico do resíduo e a influência do crômio nesta transformação. 


\section{REVISÃO DE LITERATURA}

\subsection{O Processo industrial de curtimento do couro}

O processo industrial de produção do couro possui um elevado potencial poluidor. A matéria-prima básica é de origem orgânica, empregando-se, adicionalmente, produtos químicos com características de elevada toxidez e grandes volumes de água (Equipe Técnica do Grupo MK (ETGMK), 1996).

No curtimento de peles animais e sua transformação em couro, empregase uma grande variedade de técnicas, divididas em uma série de etapas. A maioria destas operações é básica a todas as diferentes formas de tratamento das peles e podem ser químicas e/ou mecânicas. As principais etapas adotadas no curtimento de peles e seus procedimentos unitários são apresentadas a seguir (Gutierrez, 1996), ou seja: conservação da pele; operações de ribeira; curtimento e operações de acabamento.

\subsubsection{Conservação da pele}

A conservação da pele é necessária para evitar a sua degradação. Esta degradação pode ser causada pela autólise produzida pelas enzimas contidas nas células da própria pele ou pela putrefação causada pelo crescimento bacteriano. Esta degradação é muito rápida e caso a pele verde não seja processada imediatamente após o abate do animal, é necessário aplicar-se um método de conservação, que em muitas 
circunstâncias, são realizados fora do curtume. Estes procedimentos contribuirão muito para a composição do efluente e conseqüentemente com as características do resíduo gerado. Podem ser classificados em três grupos:

a) processos que utilizam sal: consistem basicamente de algumas técnicas de desidratação por meio de sua impregnação com uma solução saturada de cloreto de sódio, que impede a ação bacteriana;

b) processos que não utilizam sal: neste processo a forma mais comum é a secagem da pele, onde se realiza uma desidratação por evaporação até que as peles atinjam uma umidade compreendida entre 120 e 150 g.kg ${ }^{-1}$;

c) processos que utilizam curtimentos leves.

O processo normalmente utilizado é a conservação por salga que proporciona peles de melhor qualidade às etapas seguintes. Convém ressaltar que, freqüentemente nesta etapa, as peles são tratadas com inseticidas para evitar o ataque de besouros e outros insetos durante o período de transporte e armazenagem. Os produtos mais utilizados com esta finalidade são: bórax, piretróides, permethrin, p-diclorobenzeno e sódio-sílico-fluoreto (Adamu et al, 1994).

\subsubsection{Operações de ribeira}

Nesta etapa ocorre a preparação das peles para o curtimento. Ela é constituídas das seguintes operações: remolho, depilação e caleiro, descarne e divisão, descalcinação e purga e piquelagem. 


\subsubsection{Remolho}

Nesta operação procede-se a remoção de sangue, sal e impurezas aderidas à pele, reidratando-as até aos níveis de umidade que possuíam antes dos processos de conservação. Esta etapa deve ser realizada no menor espaço de tempo possível.

Para tanto, utiliza-se uma grande quantidade de água, sendo o remolho a etapa que individualmente apresenta o maior consumo, aproximadamente 5000 litros de água para cada tonelada de pele (ETGMK, 1996). Nesta etapa são utilizados tensoativos e bactericidas e em alguns processos, agentes remolhantes (complexo organo-fosfato alcalino) e uma enzima proteolítica de origem bacteriana, com a finalidade de aumentarse a eficiência deste processo.

Produtos químicos utilizados: hidróxido de sódio $\left(0,2-2,0\right.$ g. $\left.\mathrm{L}^{-1}\right)$, sulfato e hipoclorito de sódio (até 1 g. $\mathrm{L}^{-1}$ ) e/ou umectantes $\left(0,5-2,0\right.$ g. $\mathrm{L}^{-1}$ ), emulsificantes e preparados de enzimas (Adamu et al.,1994).

\subsubsection{Depilação e caleiro}

Nestas etapas promovem-se a degradação do sistema epidérmico e dos pêlos além de se promover a abertura da estrutura fibrosa (feixes de fibras).

Segundo Souza et al. (1991), observam-se os seguintes fatos na depilação e caleiro: ruptura, por hidrólise, da estrutura das proteínas; reação dos produtos resultantes desta hidrólise com os agentes depilantes; abertura e intumescimento da estrutura fibrosa e ação sobre gorduras e proteínas, principalmente o colagênio.

Os produtos mais utilizados nestes processos são a cal hidratada e o sulfeto de sódio. Visando diminuir a carga de poluentes gerada no sistema cal-sulfeto outras formas de depilação têm sido desenvolvidas e testadas, onde se utilizam aminas e 
álcalis, depilação enzimática, depilação com dióxido de cloro ou mesmo caleação com preservação de pêlo.

A etapa de depilação e caleiro é a etapa que libera a maior carga de Carbono Orgânico Dissolvido (COD) em todo o processo de curtimento. Hoinacki, citado pela ETGMK (1996), afirma que 70\% da $\mathrm{DBO}_{5}$ e $55 \%$ da DQO dos efluentes são originárias deste processo, quando procede-se a destruição total dos pêlos.

Os produtos químicos utilizados nesta etapa são: hidróxido de cálcio (210\%), sulfato de sódio (1-4\%) e soda cáustica (Adamu et al.,1994).

\subsubsection{Descarne e divisão}

O descarne consiste na eliminação da carnaça, ou seja, restos do tecido adiposo, subcutâneo e muscular. Após o descarne ocorre a divisão do couro em duas camadas, a superior, denominada flor, irá ser processada até sua transformação em couro. Estas operações não apresentam contribuição significativa para o efluente final.

\subsubsection{Descalcinação e purga}

O objetivo da descalcinação é remover total ou parcialmente a cal absorvida pela pele. Neste processo as peles são tratadas com sulfato de amônio, bissulfito de sódio ou ácidos orgânicos fracos, que por reação química neutralizam a alcalinidade das peles formando sais neutros (sulfato de cálcio).

A purga é realizada em conjunto com a descalcinação e visa uma limpeza da estrutura fibrosa pela eliminação de componentes indesejáveis que prejudiquem a textura do material. Nestas etapas são utilizadas soluções de enzimas proteolíticas, quais sejam: ácidos (sulfúrico, hidroclorídrico, láctico, fórmico, bórico e misturas - 0,5-2,0\%), sais de ácidos, cloreto ou sulfato de amônio, bissulfito de sódio, peróxido de hidrogênio; 
serragem ou outro carreador (50\%), agente descalcinante (cloreto de amônio 30\%) e enzimas pancreáticas (1-5\%) (Adamu et al., 1994).

\subsubsection{Piquelagem}

Nesta etapa as peles são tratadas com soluções salinas acidificadas, que preparam as fibras de colagênio para uma fácil penetração dos sais de crômio, evitando a sua precipitação durante o curtimento. $\mathrm{O}$ banho de píquel utiliza os seguintes produtos cloreto de sódio (6 a 10\%), ácido sulfúrico (1-1,5\%) e água. Pequenas quantidades de fungicidas também podem ser empregadas, tais como o thiobenzothiazol ou pentaclorofenol (Adamu et al., 1994).

\subsubsection{Curtimento}

Por meio do curtimento promove-se uma reticulação das cadeias de colagênio, aumentando a estabilidade desta estrutura que não sofre inchamento ou retração com a absorção ou eliminação de água, tornando-a resistente à degradação biológica (putrefação).

Os agentes curtentes que promovem esta reticulação podem ser de origem orgânica(taninos vegetais, sintéticos e aldeídos) ou inorgânica (sais de crômio, zircônio, alumínio e ferro). Os sais de crômio são os agentes curtentes mais utilizados, sendo o sulfato monobásico de crômio a forma mais comumente empregada.

No curtimento ao crômio, o processo é realizado de forma a que se tenha, inicialmente, uma penetração rápida dos sais de crômio entre as fibras de colagênio. Desta forma, a reatividade entre os dois deve ser baixa inicialmente, condição que após determinado momento é modificada pelo do aumento da alcalinidade do banho conseguida pela adição de bicarbonato de sódio, que aumenta a basicidade do sal de 
crômio, permitindo que eles reajam com as fibras e que ocorram mudanças estruturais nos sais ligados, conseguindo-se a reticulação. Neste processo são incorporados às peles 2,5 a $3,0 \%$ de $\mathrm{Cr}_{2} \mathrm{O}_{3}$.

Segundo Souza et al. (1991), existem diversos tipos de curtimento ao crômio, utilizados de acordo com o grau de tecnologia, controle de qualidade da empresa e matéria-prima disponivel. Esta grande diversidade certamente irá refletir-se também sobre a concentração de crômio no efluente final e, conseqüentemente, nas concentrações deste elemento no lodo gerado.

Os produtos químicos aqui utilizados são: sais de crômio trivalente (sulfato hidratado de crômio $5-12 \%$ do peso da pele), bicarbonato de sódio (1\%), formato de sódio $(0,1-0,5 \%)$, ftalatos ou sais de ácido dicarboxílico, fungicida $(0,1 \%)$ caso o produto seja armazenado ou transportado na condição de "wet blue" (Adamu et al., 1994).

\subsubsection{Operações de acabamento}

\subsubsection{Enxugamento e rebaixamento}

Após o curtimento, o couro encontra-se com uma umidade variando entre 70 e $75 \%$, sendo necessária a realização de uma secagem para possibilitar as operações de rebaixamento. Esta secagem é mecanizada e reduz a umidade das peles até 50 a $55 \%$.

A operação de rebaixamento tem por finalidade reduzir e uniformizar a espessura do couro de acordo com as necessidades requeridas. Este procedimento também facilita as operações de acabamento, que se seguirão, por meio de uma abertura das fibras, facilitando a ação dos produtos empregados. O rebaixamento é efetuado com o emprego de máquinas rebaixadeiras, gerando um resíduo sólido denominado pó de rebaixadeira. 


\subsubsection{Neutralização}

Nesta operação promove-se um aumento do $\mathrm{pH}$ do couro, que passa de 3,8-4,0 para 4,6-5,2, eliminando o excesso de acidez e permitindo uma ação uniforme dos produtos utilizados no recurtimento. Normalmente utilizam-se sais de ácidos fracos, agentes complexantes, sais de taninos sintéticos e neutralizantes especiais.

\subsubsection{Recurtimento}

O recurtiménto é realizado para proporcionar características diferenciadas aos couros, necessárias em função da sua utilização. Este curtimento complementar é feito com diversos agentes recurtentes, normalmente com uma combinação deles como por exemplo: sais metálicos (sais de crômio, alumínio, zircônio, organo-crômio e organo-alumínio), extratos vegetais (mimosa, quebracho, castanheiro, etc.), resinas (aniônicas, catiônicas, anfóteras, prepolimerizadas, monoméricas, de base uréia, melanina e acrílicas), silicatos , aldeídos, polifosfatos, enxofre e óleos recurtentes.

\subsubsection{Tingimento}

Os couros são tingidos pela sua imersão em soluções com substâncias corantes. Normalmente são utilizadas substâncias orgânicas solúveis não saturadas, como as anilinas. Esta operação pode ser conjugada ao recurtimento. 


\subsubsection{Engraxe}

No engraxe faz-se a impregnação dos couros com substâncias lubrificantes evitando que, após o processo de secagem, ocorra a cementação das fibras de colagênio, tornando-o mais macio e flexível. Para isto, utilizam-se óleos naturais, óleos naturais sulfatados, sulfitados ou sulfonados, álcoois graxos sulfatados, parafinas cloradas ou sulfocloradas e óleos minerais.

\subsubsection{Secagem}

O processo de secagem do couro é necessário para que se consiga uma completa reticulação entre as fibras de colagênio e o agente curtente e a fixação de óleos e outros produtos, devendo a umidade final ficar entre 14 e 15\%. Esta secagem pode ser realizada ao ar ou em estufas.

\subsubsection{Acabamento final}

No acabamento final são realizadas as operações de lixamento, recorte, umectação, amaciamento e eliminação do pó, que são consideradas operações de préacabamento e o acabamento propriamente dito, onde são aplicadas camadas sucessivas à base de ligantes e pigmentos que irão conferir ao couro sua apresentação e aspectos definitivos. 


\subsubsection{Geração de efluentes e resíduos sólidos}

O processo de transformação das peles em couro, conforme descrito anteriormente, gera uma grande quantidade de efluentes com uma concentração alta de produtos químicos, utilizados em excesso no processo, e material orgânico proveniente das peles. Também são gerados resíduos sólidos e semi-sólidos com composição variável, de acordo com a etapa do processo da qual é proveniente, numa quantidade de duas a três vezes o peso do produto obtido. A estas quantidades devem ser acrescentados os resíduos (lodos) oriundos do tratamento dos efluentes, anteriormente citados, que podem ser da ordem de até 1,2 vezes a quantidade de couro produzida e que terão uma composição química semelhante aquela encontrada nestes efluentes (Straus \& Silva, 1980).

O processo de produção de couro e os pontos de geração de resíduos são apresentados de forma simplificada na figura 1 , onde se verificam os seguintes resíduos sólidos gerados no processo, conforme descritos por Straus e Silva (1980):

- pêlos: normalmente utiliza-se a depilação química onde o pêlo é dissolvido pela ação de produtos químicos, sendo este resíduo somente gerado pela depilação mecânica, normalmente utilizada em peles de ovinos.

- carnaça: o descarne das peles produz um resíduo orgânico com 10 a 20\% de matéria seca, um teor de proteínas em torno de 50\%, 35\% de matéria graxa e $15 \%$ de produtos minerais como o sulfeto de sódio e cal, que não aparecerão nestes resíduos caso esta operação seja realizada antes da depilação e caleação. Por meio do cozimento deste resíduo com ácido sulfúrico obtém-se a separação do sebo e consegue-se um resíduo sólido com alto valor protéico que pode ser aproveitado na fabricação de alimento para animais. Caso a caleação já tenha sido realizada, um pré-tratamento anterior a este aproveitamento deve ser feito.

- aparas: são constituídas pelos recortes de peles e outras partes rejeitadas no processo de curtimento e acabamento. Podem ser geradas em vários pontos do processo, dando 
origem a aparas não caleadas, aquelas provenientes antes da operação de caleação, aparas caleadas ou aparas de couro curtido. Apresentam, basicamente, a mesma composição básica, acrescidas das características peculiares de cada processo em que são geradas. Por exemplo, as aparas de couro curtido possuem em sua composição um teor de 2 a 5\% de óxidos de crômio. No processo de curtimento são gerados ao todo, de 25 a $60 \mathrm{~kg}$ destes resíduos por tonelada de pele processada. Estes resíduos podem ser reaproveitados na produção de gelatina e colas no caso de aparas não curtidas e, no caso das curtidas de forma menos econômica já que existe a necessidade de prétratamento.

- serragem de rebaixamento: resíduo gerado na operação de rebaixamento da pele já curtida. Sua composição é semelhante à do couro produzido e, portanto, dependerá do tipo de curtimento empregado. No curtimento ao crômio apresenta um teor médio deste elemento de $8 \mathrm{mg} \cdot \mathrm{g}^{-1}$ em base seca. A geração deste resíduo no processo é grande, da ordem de 150 a $180 \mathrm{~kg} \cdot \mathrm{Mg}^{-1}$ de pele processada. Esta serragem pode ser aproveitada na fabricação de placas conglomeradas de couro que, entre outras utilidades, podem ser usadas na fabricação de palmilhas.

- resíduos sólidos gerados no tratamento dos efluentes : qualquer que seja a planta de tratamento de efluentes adotada, teremos sempre como resultado desta operação a geração de resíduos sólidos ou semi-sólidos (lodos) constituídos, basicamente, de lamas precipitadas, ricas em matéria orgânica de origem protéica e com alta concentração de sais, principalmente de cálcio, sódio, crômio e enxofre. A umidade destes resíduos varia entre 98 e $99 \%$ e a quantidade gerada dependerá do processo produtivo que segundo levantamento realizado pela CETESB (1980), pode variar de 100 a $170 \mathrm{~kg} \cdot \mathrm{Mg}^{-1}$ de pele processada (base seca). Estes resíduos teoricamente deveriam ser destinados a aterros industriais, entretanto, no Estado de São Paulo a destinação final do lodo é feita, predominantemente, de duas formas: em solos agrícolas, sem nenhum embasamento técnico ou em áreas de sacrifício, causando sérios problemas de contaminação do solo e da água subterrânea além de vários 
incômodos à população pela emanação de odores e atração de vetores. A utilização de solos agrícolas apresenta-se como uma alternativa atraente de tratamento e disposição final destes resíduos, tanto do ponto de vista ambiental como econômico, por promover uma reciclagem, recuperando-se elementos nutrientes para as plantas e corretivos de solo necessários a produção agrícola, beneficiando produtores rurais pela diminuição dos custos com fertilizantes e calcário e diminuindo a pressão sob os aterros.

Face aos elevados teores de material orgânico de origem protéica contido no resíduo, os teores de nitrogênio são o atrativo principal da aplicação destes lodos em solos agrícolas, devendo ser considerado também, o seu elevado potencial de neutralização da acidez do solo, conferido pelos altos teores de carbonato-cálcio. Por outro lado, os teores elevados de sódio e crômio apresentados pelo resíduo podem constituir-se em fatores limitantes à sua utilização. O primeiro por causar uma elevação da condutividade elétrica da solução do solo ou a dispersão das partículas de argila, causando uma degradação de suas propriedades físicas, e o crômio, apesar de encontrarse presente no resíduo na forma trivalente ( pouco tóxica, de baixa mobilidade no solo, e considerada essencial à nutrição humana em determinados níveis) devido à possibilidade de sua oxidação à forma hexavalente, muito móvel no solo e tóxica às plantas, aos animais e aos seres humanos, mesmo em pequenas concentrações. 


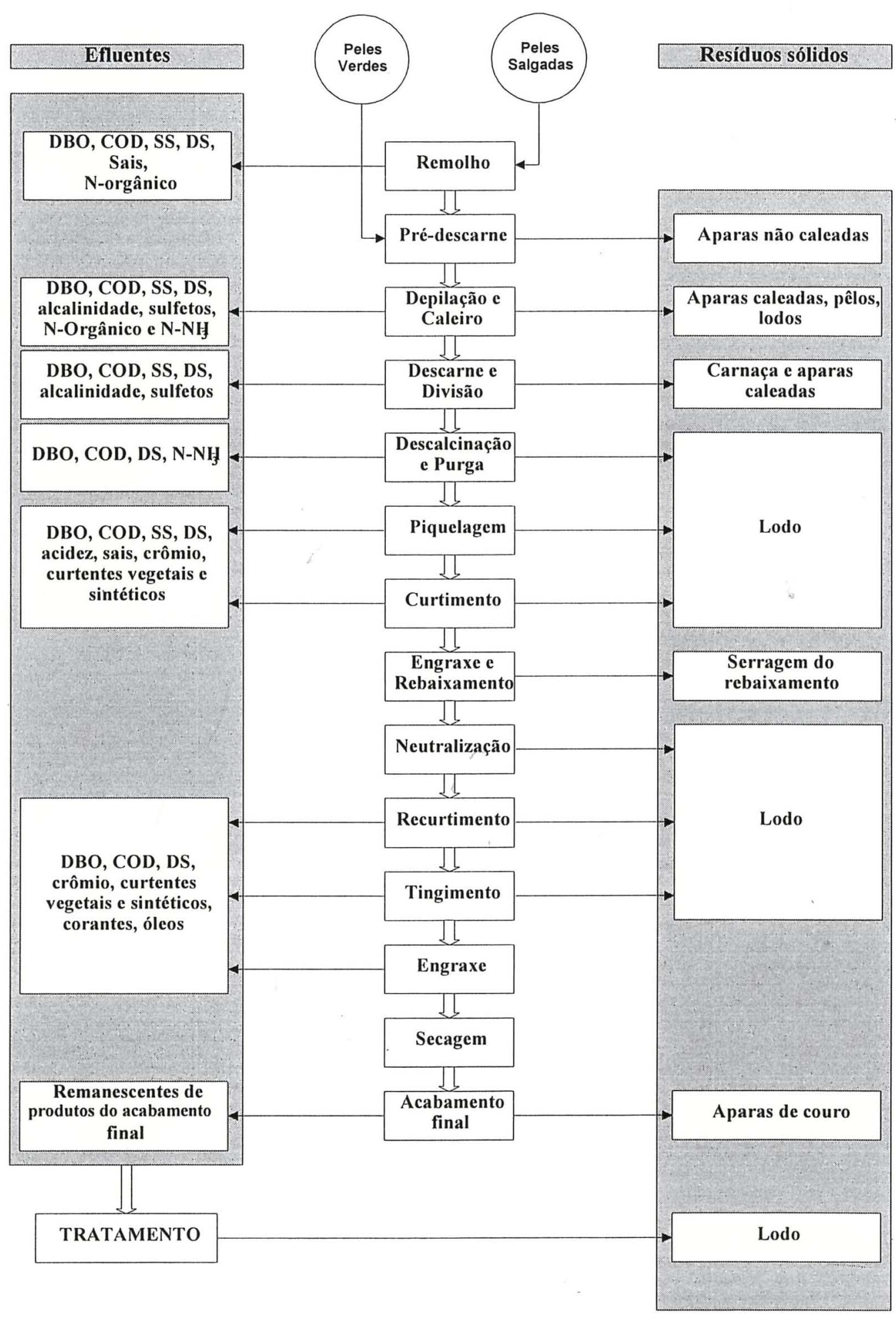

Figura 1: Diagrama do processo de curtimento de peles e geração de resíduos. 


\subsection{Crômio}

O crômio foi descoberto pelo francês Nicolas-Louis Vauquelim, que obteve sucesso ao isolar o metal em 1797 (Nriagu, 1988a). Este metal aparece de forma onipresente na natureza, figurando como o décimo sétimo elemento mais abundante na Terra, décimo elemento no manto terrestre e vigésimo primeiro elemento em maior quantidade na crosta terrestre ( Fendorf, 1995 e McGrath \& Smith, 1990 ).

Merian (1984), citado pela World Health Organization - WHO (1988), compilou uma lista das fontes de crômio para o meio-ambiente. As emissões vulcânicas representam menos de 1\%; o ciclo biológico responde por 30\% ( extração do solo pelas plantas, $15 \%$, intemperismo dos solos e rochas, $15 \%$ ) e emissões antropogênicas $70 \%$, nos quais estão incluídos a produção de metais (3\%), tratamento de metais $(60 \%)$ e queima de carvão vegetal e outros processos de combustão (7\%).

O crômio tem um amplo aproveitamento em diversos processos industriais. A maior utilização dele está concentrada na indústria metalúrgica, na produção de ligas de ferrocrômio e outros produtos como o aço inoxidável. Em menor escala também é utilizado na indústria química, na fabricação de ácido crômico e cromatos, que serão utilizados na oxidação de diversos materiais orgânicos, produção de pigmentos e como inibidor de corrosão de metais. O ácido crômico, por sua vez, tem seu maior consumo nas galvanoplastias. Outro grande consumidor deste produto é a indústria de defensivos agrícolas e preservativos de madeiras que segundo a WHO (1988), consumia aproximadamente 1,3 milhões de quilograma de crômio anualmente. $O$ dicromato é a matéria-prima utilizada na fabricação de sulfato de crômio, principal agente curtente utilizado pela indústria do couro, que segundo Papp, citado por Nriagu (1988b), consumiu 18.000 toneladas ou $15 \%$ do crômio industrializado comercializado nos EUA em 1980.

Grande parte do crômio consumido nos processos anteriormente descritos, é liberado ao meio-ambiente e recebido em estações de tratamento de 
efluentes, de origem doméstica e/ou industrial. As indústrias que possuem o crômio como uma de suas matérias-primas, apresentam efluentes com concentrações elevadas deste elemento, variando de $40 \mathrm{mg} . \mathrm{L}^{-1}$ para as curtidoras, até valores extremos de 50.000 mg. $\mathrm{L}^{-1}$ nas galvanoplastias (WHO, 1988). O tratamento destes efluentes, gera uma grande quantidade de resíduos sólidos, com concentração muito superior às dos efluentes.

\subsubsection{O crômio nos seres vivos}

\subsubsection{O crômio no homem e nos animais}

Determinado elemento é considerado um nutriente essencial quando uma redução na ingestão diária abaixo de determinado nível leva a sintomas de deficiência. A administração de doses acima deste nível deverá reverter ou prevenir estes sintomas.

Segundo esta definição, o crômio foi identificado como sendo um elemento essencial à nutrição humana, estudando-se ratos que receberam dieta deficiente deste elemento e reposição dos níveis ideais via oral. Nestes estudos o crômio foi identificado como o responsável pelo fator de tolerância à glicose ou seja, a capacidade do organismo em metabolizar níveis excessivos de glicose retornando aos níveis normais (Mertz, 1969). O mesmo autor relata que ratos ao crescerem em ambiente controlado e com dieta onde o crômio era ausente, desenvolveram diabetes na forma de síndrome.

Os principais efeitos relacionados a dietas deficientes em crômio, estão relacionados ao metabolismo da glicose, onde ele age como potencializador da insulina, entretanto outros problemas podem ser citados. Diversos estudos apresentados por WHO (1988), relacionam a deficiência de crômio na dieta de animais (ratos e coelhos) à incidência de arteriosclerose e lesões na aorta. Em coelhos que receberam dietas ricas em colesterol, a administração diária de crômio reverteu o acúmulo de placas na aorta, 
reduzindo a área ocupada por estas de $95 \%$ para $63 \%$ e o nível de colesterol de $729 \mathrm{mg}$ para $458 \mathrm{mg}$.

Mertz (1969), comenta que ratos submetidos a alimentação pobre em crômio apresentaram distúrbios na utilização de aminoácidos para a síntese protéica.

Em estudos com cobaias mantidas em ambientes controlados, observou-se que a suplementação de crômio nas dietas resultou em uma longevidade maior e um desenvolvimento superior em relação à população controle. (Mertz, 1969 e WHO, 1988).

No homem foi verificado distúrbios semelhantes quanto a deficiência de crômio, ou seja, diminuição no metabolismo da glicose em crianças mal-nutridas e em pessoas de meia-idade. Estudos epidemiológicos realizados, apontam para uma provável ligação entre a deficiência deste elemento e o aumento dos fatores que levam a um risco de desenvolvimento de doenças cardiovasculares.

Quanto aos efeitos tóxicos, devem ser consideradas além da dose de exposição, o estado de oxidação, pois segundo a WHO (1988), as formas trivalente e hexavalente do elemento, as mais estáveis no ambiente, provocam efeitos à saúde fundamentalmente diferentes.

Uma idéia da diferença de toxicidade existente entre o $\mathrm{Cr}(\mathrm{VI})$ e $\mathrm{Cr}(\mathrm{III})$ e dada pela comparação entre os valores de dose referencial de exposição oral crônica (RfD - Reference Dose for Chronic Oral Exposure), apresentados pela United States Environmental Protection Agency (USEPA) em seu Sistema Integrado de Informação de Risco (IRIS), onde se encontra:
Crômio Hexavalente -
RfD
Crômio Trivalente -
$0,005 \mathrm{mg} \cdot \mathrm{kg}^{-1} \cdot \mathrm{dia}^{-1}$
$1,000 \mathrm{mg} \cdot \mathrm{kg}^{-1} \cdot \mathrm{dia}^{-1}$

O RfD é uma estimativa da dose diária de exposição para a população humana, a partir da qual efeitos tóxicos, como a necrose celular, começarão a ocorrer. 
Esta diferença de toxicidade encontrada tem sido justificada pelo fato de o crômio hexavalente penetrar através da membrana celular com muita facilidade e ser um agente oxidante muito forte, e/ou por interagir com os constituintes da célula, dentre eles com o material genético.

O IRIS classifica o crômio hexavalente como uma substância comprovadamente carcinogênica para homens e animais. Diversos estudos epidemiológicos apresentados. encontraram uma associação entre trabalhadores submetidos a uma exposição ocupacional ao crômio e o desenvolvimento de câncer no pulmão. Ainda que estes trabalhadores, em algumas circunstâncias, estejam expostos tanto ao crômio trivalente como hexavalente, estudos realizados com animais permitem concluir que apenas a segunda forma é carcinogênica ao homem. Os valores estimados que relacionam o risco de desenvolvimento de câncer e a concentração de crômio hexavalente no ar são:

$\begin{array}{ll}\text { Nivel de risco } & \text { Concentração } \\ \text { E-4 (1 em 10.000) } & 0,00800 \mu \mathrm{g} \cdot \mathrm{m}^{-3} \\ \text { E-5 (1 em 100.000) } & 0,00080 \mu \mathrm{g} \cdot \mathrm{m}^{-3} \\ \text { E-6 (1 em 1.000.000) } & 0,00008 \mu \mathrm{g} \cdot \mathrm{m}^{-3}\end{array}$

O crômio trivalente, por sua vez, é considerado como sendo um nutriente essencial e relativamente não tóxico para humanos e mamíferos (WHO, 1988).

\subsubsection{O crômio nas plantas}

A absorção de microelementos pelas plantas é determinada por diversos fatores inerentes às suas características (espécie de planta e estádio de desenvolvimento), relacionados ao meio onde se desenvolve $(\mathrm{pH}$, material de origem, aeração, potencial redox, etc.) e relativos ao elemento (concentração e especiação do metal na solução do 
solo, formação de complexos e quelatos, etc.) (Alloway, 1990 e Pendias e Pendias, 1984).

$\mathrm{O}$ interesse pelo crômio presente no tecido vegetal, tem sido motivado pelas descobertas de sua participação em alguns processos metabólicos importantes, sendo as plantas a principal fonte para a nutrição animal e humana.

Adriano (1986), cita vários trabalhos onde se observou efeitos benéficos do crômio para as plantas, entretanto, estes efeitos geralmente mostraram-se reduzidos e inconsistentes, ao contrário da sua não essencialidade, demonstrada de forma conclusiva. Allaway (1968), abordando este assunto, relata que plantas cultivadas em condições controladas, onde induziu-se uma deficiência de crômio, apresentaram teores deste elemento nas folhas semelhantes àqueles encontrados nas cultivadas como controle.

A concentração de crômio presente na planta está associada, principalmente, à presença de formas solúveis do elemento no solo. Seu estado de oxidação exerce importante papel neste sentido. Na forma hexavalente, o crômio aparece como um ânion solúvel, que penetra facilmente através da membrana celular, possuindo uma ação tóxica aguda, por ser um forte agente oxidante. O crômio trivalente por sua vez, somente se apresenta na forma solúvel, a valores de $\mathrm{pH}$ menores daqueles normalmente encontrados em sistemas biológicos ou quando complexado com moléculas orgânicas de baixo peso molecular, que possuem pouca mobilidade através da membranas celular (Bartlett \& James, 1988).

A absorção de $\mathrm{Cr}(\mathrm{III})$ e $\mathrm{Cr}(\mathrm{VI})$ pelas plantas acontece por meio de mecanismos diferenciados. A aplicação de inibidores metabólicos à solução nutritiva reduziu a absorção de $\mathrm{Cr}(\mathrm{VI})$, demonstrando que este processo ocorre de forma "ativa", enquanto que a absorção de $\mathrm{Cr}(\mathrm{III})$ não foi afetada, indicando que neste caso, o metal penetra nas raízes por um simples mecanismo de osmose, sendo classificada como uma absorção passiva (Skeffington et al., 1976).

Adrian (1991) acrescenta que, uma vez absorvido, o crômio penetra dentro dos vacúolos das células da raiz, provavelmente associado a hidratos de ferro, que 
dificulta a difusão do elemento dentro do organismo vegetal. Outra possibilidade, segundo Huffman \& Allaway(1973), é de que o metal esteja imobilizado por meio de adsorção não específica nas paredes celulares, precipitado na superfície ou no interior das raizes. O mais provável é que a primeira situação prevaleça para o crômio hexavalente e as demais para o crômio trivalente.

A aplicação de doses elevadas de crômio ao solo, torna ineficiente o mecanismo que regula a absorção do crômio, permitindo que este elemento se transloque por toda a planta (Adrian, 1991).

Diversos estudos desenvolvidos em solução nutritiva, revelaram não haver diferença entre a absorção de $\mathrm{Cr}(\mathrm{VI})$ e $\mathrm{Cr}(\mathrm{III})$, por plantas cultivadas nestas condições (Cary et al., 1977a; Huffman \& Allaway, 1973; Mcgrath, 1982; Ramachandran et al., 1980). Esta constatação pode ser explicada pela presença de ambos os elementos em formas solúveis.

Este comportamento, entretanto, pode mudar significativamente no solo onde, além da valência do elemento, diversos outros fatores estarão interagindo, principalmente o $\mathrm{pH}$ do meio e a presença de agentes complexantes.

O $\mathrm{Cr}(\mathrm{VI})$ é considerado a forma mais tóxica para as plantas, independentemente das condições do meio, conforme observado em diversos trabalhos, como o realizado por Skelffington et al. (1976) onde brotos de cevada cultivados em solução nutritiva, tiveram o desenvolvimento radicular e da parte aérea inibidos em maior extensão no tratamento que recebeu $\mathrm{Cr}(\mathrm{VI})$, em relação ao que recebeu $\mathrm{Cr}(\mathrm{III})$, ainda que a planta tenha absorvido uma quantidade ligeiramente maior deste último. Mcgrath \& Smith (1990), afirmam que o Cr(III) apenas apresenta efeitos tóxicos para as plantas em meios muito ácidos, pois a sua biodisponibilidade é muito reduzida a $\mathrm{pH}$ superior a 5,0 .

Mcgrath (1982), conduzindo experimento em solução nutritiva, concluiu que o crômio trivalente presente como sal dissolvido, pode ser tão tóxico quanto o crômio hexavalente. Com a finalidade de estudar este comportamento no solo, montou 
ensaio onde foram aplicados $750 \mu \mathrm{g} . \mathrm{g}^{-1}$ de crômio na forma trivalente ou hexavalente, a dois solos com pH distintos $(3,9$ e 7,6). A concentração de crômio no solo foi determinada no extrato, conseguido após a lixiviação de amostra coletada. Os teores de crômio trivalente na solução do solo foram baixos, sendo maiores no solo com $\mathrm{pH}$ menor, embora tenham sido suficientes para diminuir em aproximadamente $80 \%$ a produção de matéria seca da parte aérea e raízes. A possibilidade de ter-se formado Cr(VI) não foi investigada nestas amostras. A aplicação de $\mathrm{Cr}(\mathrm{VI})$ nas mesmas condições foi letal para as plantas, tendo sido detectada uma menor concentração deste elemento no solo com pH menor. É conveniente observar-se que a dose aplicada neste estudo pode ser considerada elevada, ao contrário do realizado por Sheppard et al. (1984), que cultivaram alfafa e acelga em lisímetros, onde se colocaram nos solos $0,20 \mathrm{e}$ $50 \mathrm{mg} \cdot \mathrm{kg}^{-1}$ de $\mathrm{Cr}_{2}\left(\mathrm{SO}_{4}\right)_{3} \cdot 15 \mathrm{H}_{2} \mathrm{O}$, doses consideravelmente menores que as aplicadas no experimento apresentado anteriormente. As plantas absorveram uma quantidade de crômio proporcional à quantidade aplicada e a concentração na sua parte aérea, foi considerada relativamente alta, sendo mais elevada no solo com textura arenosa (18 e $57 \mathrm{mg} \cdot \mathrm{kg}^{-1}$ para as doses aplicadas no solo de 20 e $50 \mathrm{mg} \cdot \mathrm{kg}^{-1}$ ), entretanto nenhuma redução no crescimento das culturas foi observado.

O mesmo foi verificado por Cary et al. (1977b), quando aplicaram pequenas doses ( 0,5 e 2,0 mg.kg-1 $)$ de $\mathrm{Cr}(\mathrm{III})$ ou $\mathrm{Cr}(\mathrm{VI})$ na forma de $\mathrm{CrCl}_{3}$ ou $\mathrm{K}_{2} \mathrm{CrO}_{4}$, a solo onde foram plantadas duas variedades de aveia. Nenhum destes tratamentos causou efeito na produtividade da aveia e somente na dosagem maior de $\mathrm{Cr}(\mathrm{VI})$ na fase de emborrachamento, observou-se um incremento significativo de crômio na parte aérea. Em uma outra etapa deste experimento, doses elevadas de $\mathrm{Cr}(\mathrm{III})$, até $10 \mathrm{~g} \cdot \mathrm{kg}^{-1}$, foram aplicadas ao solo e cultivou-se alfafa e aveia. Somente nos tratamentos onde foram aplicadas as maiores doses, foi observado um incremento significativo na concentração de crômio no tecido vegetal, de ambas as culturas.

Em cstudo realizado em vasos, Bartllet \& James (1979), observaram sintomas severos de toxicidade em alfafa, feijão e mostarda, cultivadas em solo que 
recebeu 30 mmol. $\mathrm{kg}^{-1}$ de cloreto de crômio $\left(\mathrm{CrCl}_{3}\right)$. O solo utilizado foi coletado e mantido úmido, não alterando a capacidade de oxidação do $\mathrm{Cr}(\mathrm{III})$. Quando o solo foi seco, e reumedecido somente após a montagem dos vasos, os sintomas de toxicidade existiram, mas de forma mais amena. Os autores atribuíram a ação tóxica observada aos teores de $\mathrm{Cr}(\mathrm{VI})$ formados no solo pela oxidação do $\mathrm{Cr}(\mathrm{III})$. Na primeira situação, encontrou-se um valor médio de $260 \mu \mathrm{mol} . \mathrm{kg}^{-1}$ contra $20 \mu \mathrm{mol} . \mathrm{kg}^{-1}$ na segunda. Os autores não determinaram, em nenhum dos dois experimentos, a concentração do crômio trivalente presente na forma solúvel.

Os mesmos autores observaram ainda que, a cultura de feijão apresentou uma concentração de crômio na parte aérea em níveis superiores ao controle, apenas no solo que recebeu a dose mais elevada $\left(10 \mathrm{mmol}\right.$ de $\mathrm{Cr}(\mathrm{OH})_{3}$ por quilograma de solo). Esta absorção maior, foi devida ao $\mathrm{Cr}(\mathrm{VI})$ formado no solo, que atingiu uma concentração máxima três dias após a aplicação do hidróxido de crômio (James \& Bartlett, 1984).

Ápós aplicar $50 \mathrm{mg} \cdot \mathrm{kg}^{-1}$ de crômio na forma hexavalente $\left(\mathrm{CrO}_{3}\right)$ em dois solos, acrescidos ou não de aplicação de $25 \mathrm{mg} \cdot \mathrm{kg}^{-1}$ de $\mathrm{Si}(\mathrm{OH})_{4}$, e cultivar cevada, Otabbong (1990), encontrou decréscimos no peso seco da cultura, sendo moderado nos solos que receberam somente $\mathrm{Cr}(\mathrm{VI})$ e severo naqueles onde também foi aplicado o $\mathrm{Si}(\mathrm{OH})_{4}$. Estes efeitos foram mais pronunciados no solo com $\mathrm{pH}$ mais elevado e com menor teor de matéria orgânica. O efeito tóxico do crômio aplicado, segundo o autor, foi mais severo nos solos com características mais propícias a manter o estado de oxidação hexavalente. A concentração de $\mathrm{Cr}(\mathrm{VI})$ ao longo do experimento não foi monitorada.

Mortvedt \& Giordano (1975), compararam a absorção de crômio por milho, após a aplicação no solo de doses crescentes $\left(0,5,20,80,320 \mathrm{mg} \cdot \mathrm{kg}^{-1}\right)$ do metal na forma trivalente ou hexavalente. $O$ crômio trivalente foi absorvido em menor escala, acarretando redução no desenvolvimento da cultura apenas na taxa mais elevada. Neste tratamento encontrou-se uma concentração, na parte aérea da planta, de $2,8 \mathrm{mg} \cdot \mathrm{kg}^{-1}$ de Cr e produção de matéria seca de $25 \mathrm{~g}$ por pote. No controle, observou-se uma 
concentração de $1,6 \mathrm{mg} \cdot \mathrm{kg}^{-1}$ de $\mathrm{Cr}$ e uma produção de matéria seca de $55 \mathrm{~g}$ por pote. As plantas que se desenvolveram nos tratamentos onde foi aplicado o crômio hexavalente apresentaram uma redução severa na produção de matéria seca, tendo seu desenvolvimento impedido na dosagem mais elevada.

"Os sintomas de toxicidade visualmente detectáveis, causados às plantas por níveis excessivos de crômio, são: a diminuição do crescimento, atrofia no desenvolvimento radicular, enrolamento e descoloração das folhas e em algumas culturas, folhas com manchas vermelho-amarronzadas contendo pequenas áreas necróticas ou tecido basal púrpura" (Adriano, 1986). O mesmo autor apresenta um resumo de diversos trabalhos a respeito de efeitos tóxicos do crômio às plantas que são reproduzidas no quadro 1 . 
Quadro 1 Efeitos do estado de oxidação, níveis de crômio e substrato no desenvolvimento das plantas (Adriano, 1986).

\begin{tabular}{|c|c|c|c|c|c|}
\hline Espécie & $\begin{array}{l}\text { Estado de } \\
\text { oxidação }\end{array}$ & $\begin{array}{l}\text { Concentração } \\
\text { de crômio } \\
\text { mg.kg }\end{array}$ & Substrato & Efeitos & Fonte \\
\hline Milho & $\mathrm{Cr}(\mathrm{III})$ & 0,5 & $\begin{array}{l}\text { solução } \\
\text { nutritiva }\end{array}$ & estimulou o crescimento & $\begin{array}{l}\text { NRCC } \\
(1976)\end{array}$ \\
\hline Milho & $\mathrm{Cr}(\mathrm{III})$ & 5,0 & $\begin{array}{l}\text { Solução } \\
\text { nutritiva }\end{array}$ & Toxicidade moderada & $\begin{array}{l}\text { NRCC } \\
(1976)\end{array}$ \\
\hline Milho & $\mathrm{Cr}(\mathrm{III})$ & 50 & $\begin{array}{c}\text { solução } \\
\text { nutritiva }\end{array}$ & $\begin{array}{c}\text { Inibição severa do } \\
\text { crescimento }\end{array}$ & $\begin{array}{l}\text { NRCC } \\
(1976)\end{array}$ \\
\hline Azevém & $\mathrm{Cr}(\mathrm{III})$ & 10 & $\begin{array}{l}\text { solução } \\
\text { nutritiva }\end{array}$ & $\begin{array}{l}\text { Aumento da mortalidade } \\
\text { das plantas }\end{array}$ & $\begin{array}{l}\text { NRCC } \\
(1976)\end{array}$ \\
\hline Azevém & $\mathrm{Cr}(\mathrm{VI})$ & 10 & $\begin{array}{l}\text { solução } \\
\text { nutritiva }\end{array}$ & $\begin{array}{c}\text { Aumento da mortalidade } \\
\text { das plantas }\end{array}$ & $\begin{array}{l}\text { NRCC } \\
(1976)\end{array}$ \\
\hline cevada & $\mathrm{Cr}(\mathrm{VI})$ & 50 & Solo & $\begin{array}{c}\text { Inibição severa do } \\
\text { crescimento }\end{array}$ & $\begin{array}{l}\text { NRCC } \\
(1976)\end{array}$ \\
\hline cevada & $\mathrm{Cr}(\mathrm{VI})$ & 500 & Solo & Morte & $\begin{array}{l}\text { NRCC } \\
(1976)\end{array}$ \\
\hline Aveia & $\mathrm{Cr}(\mathrm{VI})$ & 5 & Areia & Clorose & $\begin{array}{l}\text { NRCC } \\
(1976) \\
\end{array}$ \\
\hline Beterraba & $\mathrm{Cr}(\mathrm{VI})$ & 8 & Areia & Clorose & $\begin{array}{l}\text { NRCC } \\
(1976) \\
\end{array}$ \\
\hline Tabaco & $\mathrm{Cr}(\mathrm{VI})$ & 5 & Areia & $\begin{array}{c}\text { Retardamento do } \\
\text { desenvolvimento da haste }\end{array}$ & $\begin{array}{l}\text { NRCC } \\
(1976)\end{array}$ \\
\hline Milho & $\mathrm{Cr}(\mathrm{VI})$ & 10 & Areia & Inibição do crescimento & $\begin{array}{l}\text { NRCC } \\
(1976) \\
\end{array}$ \\
\hline $\begin{array}{c}\text { Brotos de } \\
\text { laranja }\end{array}$ & $\mathrm{Cr}(\mathrm{VI})$ & 75 & Solo & Nenhuma sintoma & $\begin{array}{l}\text { NRCC } \\
(1976)\end{array}$ \\
\hline $\begin{array}{c}\text { Brotos de } \\
\text { laranja }\end{array}$ & $\mathrm{Cr}(\mathrm{VI})$ & 150 & Solo & Observada toxicidade & $\begin{array}{l}\text { NRCC } \\
(1976)\end{array}$ \\
\hline Soja & $\operatorname{Cr}(\mathrm{VI})$ & 5 & Solo & $\begin{array}{c}\text { Inibição da absorção de } \\
\mathrm{Ca}, \mathrm{K}, \mathrm{P}, \mathrm{B} \text { e } \mathrm{Cu}\end{array}$ & $\begin{array}{l}\text { NRCC } \\
(1976)\end{array}$ \\
\hline cevada & $\mathrm{Cr}$ (III) & 8 & $\begin{array}{l}\text { Solução } \\
\text { Nutritiva }\end{array}$ & Clorose nas folhas & $\begin{array}{c}\text { Davis et al. } \\
(1978)\end{array}$ \\
\hline Feijão & $\mathrm{Cr}(\mathrm{III})$ & 0,5 & $\begin{array}{c}\text { Solução } \\
\text { Nutritiva } \\
\end{array}$ & $\begin{array}{l}\text { Diminuição da } \\
\text { produtividade }\end{array}$ & $\begin{array}{c}\text { Wallace et al. } \\
(1976)\end{array}$ \\
\hline Milho & $\mathrm{Cr}(\mathrm{III})$ & 100 & Solo & Inibição do crescimento & $\begin{array}{c}\text { Schueneman } \\
(1974)\end{array}$ \\
\hline Tomate & $\mathrm{Cr}$ (III) & 100 & Solo & Inibição do crescimento & $\begin{array}{c}\text { Schueneman } \\
(1974)\end{array}$ \\
\hline Feijão & Cr(III) & 100 & Solo & Inibição do crescimento & $\begin{array}{c}\text { Schueneman } \\
\text { (1974) }\end{array}$ \\
\hline
\end{tabular}


Pode-se afirmar que uma quantidade muito pequena do crômio absorvido pelas raízes transloca-se para a parte aérea das plantas. Este fato tem sido observado, independentemente do estado de oxidação em que este elemento foi adicionado ao solo ou à solução nutritiva. Lahouti \& Peterson (1979), cultivando diversas culturas em solução nutritiva, que apresentava uma concentração de crômio de $25.10^{-3} \mu \mathrm{M}$ na forma de ${ }^{51} \mathrm{Cr}(\mathrm{III})$ ou ${ }^{51} \mathrm{Cr}(\mathrm{VI})$, encontraram que aproximadamente $98 \%$ do elemento absorvido permaneceu retido nas raízes. Comportamento semelhante foi observado por Shewry \& Peterson (1974), após aplicarem ${ }^{51} \mathrm{CrO}_{4}{ }^{2-}$. Apenas $1 \%$ do isótopo absorvido foi translocado para a parte aérea.

Os teores de crômio nas raízes de cevada, cultivada em solução nutritiva, foram quarenta vezes maiores do que o encontrado na parte aérea, em experimento realizado por Barcelo et al. (1985). Esta acumulação de crômio nas raízes também foi observada por Cary et al. (1977), Huffman e Allaway (1973), Mortvedt \& Giordano (1975), Ramachandran et al. (1980) e Selbach et al. (1991).

James \& Bartlett (1984) assumem que, no solo, o $\mathrm{Cr}$ (VI) é preferencialmente absorvido por apresentar maior biodisponibilidade. Após esta absorção, é reduzido à forma trivalente e retido nas raízes, em formas insolúveis, como complexo orgânico solúvel ou fortemente adsorvido, não se translocando à parte aérea. Entretanto, quando adicionaram ácido cítrico ao solo $\left(2 \mathrm{mmol} . \mathrm{kg}^{-1}\right)$, que recebeu uma aplicação de $10 \mathrm{mmol}^{-1} \mathrm{~kg}^{-1}$ de $\mathrm{Cr}(\mathrm{OH})_{3}$, encontraram um aumento na concentração do metal absorvido no tecido da parte aérea da planta de 25 para $42 \mathrm{mg}$ de crômio. $\mathrm{kg}^{-1}$ (peso seco). Isto foi motivado pelo aumento da concentração de $\mathrm{Cr}$ (III) em solução e de $\mathrm{Cr}(\mathrm{VI})$ formado, resultantes da adição de ácido cítrico ao solo. Os autores também observaram, nos tratamentos onde não foi aplicado ácido cítrico, um aumento na concentração de $\operatorname{Cr}(\mathrm{III})$ em solução do solo da rizosfera. Concluíram que os ácidos orgânicos exudados pelas raízes, agem de maneira semelhante ao citrato, formando complexos orgânicos com o crômio e aumentando sua solubilidade. 
A aplicação de EDTA e NTA nas doses de 0 e $100 \mathrm{mg} \cdot \mathrm{kg}^{-1}$ a solo que recebeu 0,50 e $100 \mathrm{mg} \cdot \mathrm{kg}^{-1}$ de crômio trivalente $\left[\mathrm{Cr}_{2}(\mathrm{SO} 4)_{3}\right]$, aumentou a toxicidade do crômio para a cultura do feijão. Este efeito foi maior nos tratamentos que receberam EDTA, e foi crescente com as doses de crômio aplicadas. Experimento semelhante em solução nutritiva não apresentou efeito tão diferenciado, uma vez que, o sal de crômio encontrava-se em grande parte na forma solúvel (Wallace et al., 1976).

Cary et al. (1977a), observaram que o complexo Cr-EDTA, presente em solução nutritiva onde foram cultivadas diversas culturas (trigo, milho, batata, tomate, ervilha e feijão), foi absorvido pelas raizes em menor quantidade do que as demais fontes de crômio estudadas $\left(\mathrm{CrCl}_{3}, \mathrm{Na}_{2} \mathrm{CrO}_{4}, \mathrm{Cr}\right.$-oxalato, $\mathrm{Cr}$-metionina e Cr-citrato). Entretanto, foi facilmente translocado das raízes para a parte aérea das plantas, apresentando a menor relação $\mathrm{Cr}$-raiz/Cr-parte aérea.

O crômio presente em resíduos sólidos (lodos) encontra-se, via de regra, no estado de oxidação trivalente. Uma grande parte deste elemento no resíduo, encontrase complexado pela matéria orgânica ou precipitado na forma de $\mathrm{Cr}(\mathrm{III})$, formas de difícil assimilação pela planta.

Dudka \& Chlopecka (1990), encontraram uma associação entre o crômio e a fração orgânica de lodos de esgoto, muito significativa, após realizarem uma extração seqüencial em solo tratado com lodo contendo elevada concentração do metal. As frações analisadas foram: crômio trocável, ligado a carbonatos, ligado a óxidos de ferro e manganês, ligado à matéria orgânica e residual. A concentração do crômio nestas frações foi, respectivamente: $1,20,560,340$ e 160 g.kg-1.

A aplicação de lodo de esgoto enriquecido com metais ao solo, realizada por Smilde (1981), resultou em um aporte de crômio( 1000,2000 e $3000 \mathrm{mg} \cdot \mathrm{kg}^{-1}$ de crômio) muito acima dos valores orientadores especificados na Holanda, onde foi realizado este experimento. Nesta situação, a alface foi a única das culturas plantadas, onde se observou um acúmulo crescente do metal na parte aérea. De acordo com as 
doses aplicadas, a concentração no tecido vegetal foi de: 6,$7 ; 8,3$ e 13,4 mg. $\mathrm{kg}^{-1}$ de crômio enquanto que no controle foi de 3,0 mg.kg ${ }^{-1}$.

Estudando alterações provocadas pela aplicação de resíduos de curtume ao solo, Wickliff et al. (1982), observaram decréscimo na produção de matéria seca de "Erva carneira", somente no tratamento que proporcionou a máxima aplicação de crômio (1300 kg.ha ${ }^{-1}$ de crômio), quando as plantas apresentaram uma produção de matéria seca inferior a $6 \%$ e o acúmulo de crômio na parte aérea foi três vezes maior em relação ao tratamento controle. A elevada concentração de sais no solo causada por esta aplicação, impediu a atribuição destes resultados à concentração do metal no solo.

Observação semelhante foi realizada por Sykes et al.(1981), após aplicarem lodo de curtume (decantação primária), fertilizante orgânico fabricado com resíduos de curtume e lodo de esgoto oriundo de estação de tratamento com grande contribuição de efluentes de curtumes. O solo, recebeu uma aplicação destes resíduos que resultou em uma dosagem de crômio de 0, 100, 500 e 1000 mg.kg ${ }^{-1}$. Foram cultivadas as seguintes culturas: rabanete, forragem, alface e feijão. As doses de $500 \mathrm{e}$ $1000 \mathrm{mg} \cdot \mathrm{kg}^{-1}$ de crômio no solo, causaram uma diminuição na produtividade da alface que, segundo os autores, não foi devido à aplicação do metal, mas pela ação ou interação de outros componentes presentes nos resíduos como a acumulação excessiva de sais no solo, resultantes das elevadas taxas aplicadas. Não foi observado aumento significativo da concentração de crômio na parte aérea de nenhuma das culturas, com exceção feita ao feijão para a dose mais elevada. A alface e o feijão apresentaram uma elevação da concentração de crômio nas raízes.

Devido à sua capacidade de absorver metais pesados e acumulá-los na parte comestível da planta, a alface é freqüentemente utilizada para realização de ensaios de biodisponibilidade destes elementos. Em estudo desta natureza Figliolia et al.(1992) cultivou alface em solo onde foi aplicado resíduo de curtume. A alface teve seu peso seco final afetado em todos os tratamentos realizados, que variou inversamente com a dose de crômio aplicada. Entretanto, apenas no tratamento onde foram aplicados 
$200 \mathrm{mg} \cdot \mathrm{kg}^{-1}$ de crômio, é que se observou um aumento significativo na concentração do metal na parte aérea da planta. Nesta taxa as folhas apresentavam uma concentração de $11,1 \mathrm{mg} \cdot \mathrm{kg}^{-1}$ (base seca) para o solo de textura arenosa e $4,4 \mathrm{mg} \cdot \mathrm{kg}^{-1}$ para o solo de textura média.

Grunbinger et al.(1994), investigaram a absorção de crômio por acelga, cultivada em solo tratado com fertilizante orgânico fabricado a partir de resíduos de curtume. A concentração de crômio no fertilizante era de $5900 \mathrm{mg} \cdot \mathrm{kg}^{-1}$.As doses aplicadas ao solo resultaram em uma concentração de $0,5,10$ e $15 \%$ do fertilizante, correspondendo a uma aplicação de $0,295,590$ e $885 \mathrm{mg} \cdot \mathrm{kg}^{-1}$ de crômio, respectivamente. Observaram-se diferenças significativas na concentração de crômio da parte aérea das plantas em relação ao controle $\left(3,03 \mathrm{mg} \cdot \mathrm{kg}^{-1}\right)$, para os tratamentos onde foram aplicados $590 \mathrm{mg} \cdot \mathrm{kg}^{-1}\left(4,90 \mathrm{mg} \cdot \mathrm{kg}^{-1}\right)$ e $885 \mathrm{mg} \cdot \mathrm{kg}^{-1}\left(6,90 \mathrm{mg} \cdot \mathrm{kg}^{-1}\right)$. Estas doses diminuíram o desenvolvimento da planta. Os autores alertam para os fatos de as doses aplicadas terem sido exageradas e o experimento ter sido realizado em vasos onde, devido ao confinamento das raízes, espera-se uma absorção maior. Experimentos realizados em campo por Stomberg et al.(1984), não apresentou diferenças significativas para a absorção de crômio entre o tratamento testemunha e o que recebeu doses elevadas

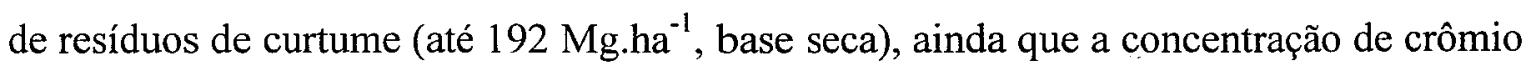
no solo tenha aumentado muito com as aplicações.

\subsubsection{O crômio no solo}

$\mathrm{O}$ crômio pode ser encontrado no solo em concentrações traços até maiores que 4.000 mg. $\mathrm{kg}^{-1}$, de acordo com o material que deu origem ao solo. A US Academy of Science (1974), citada por WHO (1988), encontrou uma concentração média de crômio nas rochas graníticas de $5 \mathrm{mg} \cdot \mathrm{kg}^{-1}$ (variação de 2 a $60 \mathrm{mg} \cdot \mathrm{kg}^{-1}$ ) e em rochas ultrabásicas e serpentinitas, $1800 \mathrm{mg} \cdot \mathrm{kg}^{-1}$ (variação de 1100 a $3400 \mathrm{mg}^{-\mathrm{kg}^{-1}}$ ). 
O crômio pode ocorrer naturalmente em diversos estados de oxidação, variando entre -2 até +6 , entretanto, no solo, as formas mais estáveis são a trivalente e a hexavalente, que possuem propriedades químicas muito distintas neste meio.

\subsubsection{Crômio III no solo}

O crômio trivalente é o estado de oxidação mais estável no solo e, como já discutido anteriormente, essencial na nutrição humana. Apresenta efeitos tóxicos às plantas somente em concentrações elevadas, quando em ambiente que possibilite a sua permanência em solução. Uma das principais caracteristicas deste metal que possibilita a sua utilização em diversas atividades industriais, é a tendência muito forte em formar compostos coordenados, complexos e quelatos, com uma taxa de troca de ligantes muito baixa, conferindo-lhe elevada estabilidade.

Bartlett \& James (1988), fazem uma analogia entre o comportamento do $\mathrm{Cr}(\mathrm{III})$ e o do $\mathrm{Al}(\mathrm{III})$. Estes dois elemento são encontrados no solo em estreita associação, possuindo raios atômicos e potenciais iônicos muito próximos. Desta forma, a substituição de um pelo outro em minerais e estruturas orgânicas é muito comum. São considerados ácidos fortes, segundo a classificação de Lewis e aparecem em meio aquoso, como íons hexahidratados $\left[\mathrm{M}\left(\mathrm{H}_{2} \mathrm{O}\right)_{6}\right]^{3+}$, possuem facilidade em formar complexos hexacoordenados com o oxigênio e complexos polinucleados solúveis por um processo chamado "olation", quando as ligações são realizadas por meio dos grupos hidroxilas, precipitando como compostos insolúveis acima de um $\mathrm{pH}$ levemente abaixo de 7,0. A valores elevados de $\mathrm{pH}$, tornam-se ânions e formam complexos muito fortes com o fosfato e substâncias orgânicas. A grande diferença entre estes elementos está na capacidade do $\mathrm{Cr}(\mathrm{III})$ em doar elétrons e sofrer oxidação, fato que não ocorre com o Al(III). 


\subsection{Precipitação - adsorção}

O crômio trivalente está presente como cátion, entre os pH 4,0 e 8,0 , como produto de primeira ou segunda hidrólise. Esta hidrolização está diretamente correlacionada com a reatividade do íon, uma vez que, a ruptura da esfera de coordenação simétrica que o metal forma com a água, diminui progressivamente a sua reatividade.

A elevação do $\mathrm{pH}$ intensifica a hidrolização do metal, diminuindo a sua solubilidade pela formação de macro-moléculas, resultantes da união dos íons de $\mathrm{Cr}$ (III), por meio dos grupos de hidroxilas. Mertz (1969).

Bartlett e Kimble(1976a) observaram uma completa precipitação do crômio trivalente a partir de $\mathrm{pH}$ 5,5, diminuindo até 4,5 para o solo.

A coprecipitação do $\mathrm{Cr}$ com o Fe apresenta importância considerável no controle da solubilidade do crômio em nossas condições, uma vez que o $\left(\mathrm{Cr}_{\mathrm{x}} \mathrm{Fe}_{1-\mathrm{x}}\right)(\mathrm{OH})_{3}$, apresenta uma solubilidade menor do que o $\mathrm{Cr}(\mathrm{OH})_{3}$ e o ferro está presente em grandes quantidades em nossos solos (Sass \& Rai citados por Rai et al., 1989).

Agindo como ácido forte, a hidrólise do $\mathrm{Cr}(\mathrm{III})$ promove um decréscimo do $\mathrm{pH}$ da solução do solo e resulta em sua precipitação, em uma reação semelhante à observada para o alumínio, exemplificada a seguir, conforme proposta por Grove \& Ellis (1980a):

$$
\mathrm{Cr}^{3+}+6 \mathrm{H}_{2} \mathrm{O} \Leftrightarrow \mathrm{Cr}\left(\mathrm{H}_{2} \mathrm{O}\right)_{6}{ }^{3+} \Leftrightarrow\left[\mathrm{Cr}(\mathrm{OH})_{x}(\mathrm{H} 2 \mathrm{O})_{6-x}\right]+x \mathrm{H} \Leftrightarrow 1 / 2 \mathrm{Cr}_{2} \mathrm{O}_{3} z \mathrm{H}_{2} \mathrm{O}
$$

A adsorção do $\mathrm{Cr}(\mathrm{III})$ pelos minerais do solo pode ser considerável, acontecendo em ampla faixa de $\mathrm{pH}$, de acordo com a composição mineralógica.

Dubbin \& Goh (1995), observaram que a montmorilonita possui uma grande capacidade de adsorção deste metal, em níveis superiores a $1000 \mathrm{cmol}(+) \cdot \mathrm{kg}^{-1}$. Devido à formação de um complexo de esfera interna de superfície entre o $\mathrm{Cr}$ (III) e o 
grupo siloxana do mineral, o metal fica fortemente ligado, sendo muito difícil a sua liberação por reações de troca mais simples. Fendorf et al.(1994), realizando análise utilizando "Extended X-ray Absorption Fine Struture Spectroscopy" (EXAFS), demonstrou que o $\mathrm{Cr}$ (III) adsorvido à sílica, forma um complexo de superfície monodentado.

Esta adsorção é mais eficiente a valores baixos de pH. A montmorilonita e a caulinita adsorveram fortemente o $\mathrm{Cr}$ (III) quando o $\mathrm{pH}$ era menor do que 4,0. Acima deste valor, a precipitação passa a ser o fator mais importante de imobilização do metal, predominando a valores de $\mathrm{pH}$ acima de 5,0. Griffin et al.(1977).

$\mathrm{O}$ aumento do $\mathrm{pH}$ eleva a relação $\mathrm{Cr} / \mathrm{OH}$, utilizada por Rengasamy \& Oades (1978), para quantificar a adsorção de $\mathrm{Cr}(\mathrm{III})$. Os autores verificaram que o aumento da relação $\mathrm{Cr} / \mathrm{OH}(\mathrm{pH})$, resulta em uma maior adsorção para os três minerais analisados (caulinita, bentonita e ilita), entretanto, as observações foram realizadas até um $\mathrm{pH}$ máximo de 4,4 , quando ainda observa-se uma pequena influência da precipitação.

A precipitação e a adsorção são, portanto, mecanismos eficientes na imobilização do $\mathrm{Cr}$ (III) no solo, devendo ser consideradas quanto à adoção de medidas de remediação em áreas que sofreram contaminação por este metal.

\subsection{Complexação}

A complexação do $\mathrm{Cr}(\mathrm{III})$ por compostos orgânicos afeta a sua solubilidade, fazendo que o metal continue solúvel com a elevação do $\mathrm{pH}$ acima de 5,5, quando as formas não complexadas precipitam.

Após o tratamento do solo com diversos compostos orgânicos, Bartlett \& Kimble (1976a), verificaram que $18 \%$ do crômio trivalente aplicado ao solo continuou solúvel à um $\mathrm{pH} 5,5$, onde foi aplicado restos vegetais de alfafa. Este tratamento foi até dez vezes mais eficiente que os demais (estercos de vaca, galinha, cavalo e ovelha). 
Neste mesmo estudo, a adição de citrato manteve $86,0 \%$ do $\mathrm{Cr}(\mathrm{III})$ em solução, indicando que, o grau de decomposição do composto orgânico está relacionada com a quantidade de grupos ativos em complexar o metal.

Em outro estudo semelhante, James \& Bartlett (1983a), demonstraram que o $\mathrm{Cr}$ (III) forma complexos solúveis com compostos orgânicos, presentes na solução do solo. O complexo formado entre o ácido cítrico (Citrato/Cr $=1 / 1$ ) e o crômio permaneceu solúvel até um $\mathrm{pH}$ 7,5 ou maior, quando a proporção entre os dois foi elevada a 10/1. O DTPA, outro ácido carboxílico, diferenciou-se do citrato entre o $\mathrm{pH}$ 6,0 e 7,0, quando teve uma solubilidade menor. Resultado semelhante foi verificado para polímeros orgânicos como o ácido fúlvico, que ao se complexar com o crômio, impediu a sua precipitação até um pH maior que 8,0, quando a proporção entre os dois foi de 10/1 (fulvato/Cr). A matéria orgânica solúvel manteve o $\mathrm{Cr}(\mathrm{III})$ em solução até um $\mathrm{pH}$ superior à 7,0 .

Neste trabalho, foi observado que, todo o crômio presente em solução acima de $\mathrm{pH} 7,0$, estava complexado com o ácido fúlvico ou cítrico quando a proporção entre eles e o metal foi de 1/1. Quando esta proporção foi elevada para 10/1, mesmo a baixos valores de $\mathrm{pH}, 100 \%$ do crômio em solução encontrava-se complexado por estas substâncias. Após o $7^{\circ}$ dia de incubação a concentração de $\mathrm{Cr}$ solúvel decresceu mesmo quando na forma complexada, entretanto, nestes tratamentos 10 a $20 \%$ do crômio inicialmente aplicado permaneceu em solução por um período de um ano em solos onde o pH variou entre 5,1 e 6,7 (James \& Bartlett, 1983a). A adsorção do Cr-citrato (ânion) às cargas positivas dos óxidos de ferro, foi considerada a causa do seu desaparecimento da solução. A adsorção foi seguida de uma degradação muito lenta, sugerindo que a complexação torna o citrato menos disponível para os microrganismos do solo. 


\subsection{Oxidação}

A oxidação do $\mathrm{Cr}(\mathrm{III})$ adicionado ao solo foi detectada por Bartlett \& James em 1979. Em seu primeiro estudo, Bartlett \& Kimble (1976a), não detectaram a formação de $\mathrm{Cr}(\mathrm{VI})$ em solos tratados com $\mathrm{Cr}(\mathrm{III})$, previamente secos ao ar e armazenados. Em seguida, observou-se que este procedimento muda, consideravelmente, o potencial redox dos constituintes orgânicos e minerais do solo, que não são restabelecidos imediatamente com o reumedecimento (Bartlett \& James, 1980).

Bartlett \& James (1979), observaram que parte do Cr(III) aplicado a solos, recém-coletados e mantidos à umidade de campo, sofreu oxidação rápida no solo, em uma reação que foi favorecida em pH menores do que 5. Neste estudo, foi demonstrada que a reação de oxidação do Cr(III) é resultado de uma interação deste metal com óxidos de $\mathrm{Mn}$ facilmente redutíveis presentes no solo. Estes óxidos atuam como receptores de elétrons, funcionando como uma ponte entre o $\mathrm{Cr}$ (III) e o oxigênio da atmosfera. Como resultado da oxidação do crômio trivalente, observou-se um aumento na quantidade de Mn(II) trocável, ocasionada pela redução dos óxidos deste elemento durante a reação. Os autores encontraram uma correlação alta, entre a quantidade de $\mathrm{Mn}$ reduzido e removido por hidroquinona 0,02M e a quantidade de $\mathrm{Cr}(\mathrm{III})$ oxidado. Eary \& Rai (1987) estudando a reação de oxidação do $\mathrm{Cr}(\mathrm{III})$ por pirolusita $\left[\beta-\mathrm{MnO}_{2}(\mathrm{~s})\right]$, constataram uma relação direta entre a quantidade de $\mathrm{Cr}(\mathrm{VI})$ formada e a concentração de óxidos de $\mathrm{Mn} \mathrm{em}$ solução.

A pirolusita é uma forma mais cristalizada de óxido de manganês, possuindo uma menor reatividade com o crômio, sendo observado por Eary \& Rai (1987), que aproximadamente $21 \%$ do $\mathrm{Cr}(\mathrm{III})$ aplicado oxidou-se após $600 \mathrm{~h}$ de incubação.

Para outros óxidos de manganês, a reação de oxidação tende a ocorrer com maior intensidade, e ser muito rápida inicialmente, seguida de uma fase lenta e gradualmente decrescente. Fendorf \& Zasoski (1992) verificaram que até $100 \%$ do 
$\mathrm{Cr}$ (III) aplicado foi oxidado à forma hexavalente, ao reagir com a birnessita [ $\delta$ $\mathrm{MnO}_{2}(\mathrm{~s})$ ], forma mais comum de óxido de $\mathrm{Mn}$ encontrada no solo. Observação semelhante foi realizada por Johnson \& Xyla (1991), para a oxidação do Cr(III) na superfície da manganita $(\gamma-\mathrm{MnOOH})$, onde $80 \%$ do metal aplicado oxidou-se após 180 segundos de reação.

Bartlett \& James (1979) apresentam cinco semi-reações de oxidação do $\mathrm{Cr}(\mathrm{III})$ e quatro de redução do $\mathrm{Mn}$, que proporcionam vinte possíveis combinações. Dezesseis destas combinações apresentam valor positivo para o logaritmo da constante de equilíbrio, indicando que estas são reações espontâneas.

De uma forma geral, a oxidação do $\mathrm{Cr}$ (III) pelo $\mathrm{MnO}_{2}$ pode ser representada pela seguinte reação:

$$
3 \mathrm{MnOOH}+\mathrm{Cr}(\mathrm{OH})^{2+}+2 \mathrm{H}^{+} \Leftrightarrow 3 \mathrm{Mn}^{2+}+\mathrm{HCrO}_{4}{ }^{1-}+3 \mathrm{H}_{2} \mathrm{O}
$$

Uma vez que esta reação de oxidação consome prótons, e desde que a solubilidade do $\mathrm{Cr}(\mathrm{III})$ é muito pequena abaixo de $\mathrm{pH}$ 5,5, espera-se que a reação de oxidação seja favorecida em ambiente ácido. ( Bartlett \& James, 1979; Eary \& Rai, 1987 e Fendorf \& Zasoski, 1992 ). Johnson \& Xyla (1991), por sua vez, concluíram que a oxidação do $\mathrm{Cr}(\mathrm{III})$ é independente do $\mathrm{pH}$, variando apenas a disponibilidade deste metal. Trebien (1994) afirma que a reação de oxidação é favorecida em condições de umidade do solo (próximas à capacidade de campo), nas quais os óxidos de Mn (III / IV) são mais estáveis.

Portanto, pode se afirmar que a reação de oxidação do $\mathrm{Cr}$ (III) pelos óxidos de manganês do solo, é controlada pelas características da superfície dos óxidos e pela disponibilidade do crômio para interagir com esta superfície.

A transferência de elétrons necessária à oxidação do crômio é possibilitada pela formação de um complexo de esfera interna deste elemento com a superfície do óxido de manganês que permite um alinhamento ideal dos orbitais. Esta 
transferência é facilitada pela formação de uma ponte entre o $\mathrm{Cr}(\mathrm{III})$ e o $\mathrm{Mn}(\mathrm{IV}) / \mathrm{Mn}(\mathrm{III})$, por meio do átomo de oxigênio. Desta forma, elétrons são transferidos do $\mathrm{Cr}(\mathrm{III})$ para o oxigênio e deste para o Mn, acompanhado de uma mudança de ligação, passando o oxigênio a estar ligado ao crômio. O complexo formado é bidentado, estando o $\mathrm{Cr}$ (III) ligado a dois átomos de oxigênio, que por sua vez, estarão ligados a dois átomos de Mn(IV), um receberá um elétron e o outro dois (Fendorf et al., 1992).

A reação de oxidação do $\mathrm{Cr}(\mathrm{III})$ pode ser inibida por diversos fatores. Fendorf et al. (1992), apresentam várias hipóteses para a ocorrência de inibição da oxidação do Cr(III) em solos com potencial para que esta reação ocorra: (1) adsorção do Mn(II) que é liberado durante o processo de oxidação, (2) adsorção do Cr(VI) aos óxidos de Mn, (3) mudança na valência das espécies de Mn adsorvidas e (4) precipitação de hidróxidos de crômio na superfície dos óxidos.

Utilizando estudos realizados por técnicas de microscopia e espectroscopia, os autores concluíram que a precipitação de $\mathrm{Cr}(\mathrm{OH})_{3} \cdot n \mathrm{H}_{2} \mathrm{O}$ na superfície dos óxidos de Mn é o principal mecanismo inibidor da oxidação do $\mathrm{Cr}$ (III).

Por ser um precipitado reduzido muito estável, o $\mathrm{Cr}(\mathrm{OH})_{3} \cdot n \mathrm{H}_{2} \mathrm{O}$ não sofre oxidação, ao mesmo tempo em que forma uma barreira entre o $\mathrm{Cr}(\mathrm{III})$ em solução e o óxido de $\mathrm{Mn}$, impedindo que ocorra a formação de um complexo de esfera interna de superfície entre os dois.

A formação de precipitados de outros metais, como o Fe e o Al, de forma similar ao observado para o crômio, também alteram o potencial de oxidação do $\operatorname{Cr}(\mathrm{III})$, conforme constataram, Fendorf et al., citados por Fendorf (1995).

A adsorção do $\operatorname{Cr}($ III) por outros minerais do solo, que não os óxidos de manganês, também constitui-se em um eficiente processo de inibição da oxidação do Cr(III), pelo simples fato de esta reação ocorrer somente na superfície destes óxidos.

Quando não está em solução, o $\mathrm{Cr}(\mathrm{III})$ pode estar indisponivel para sofrer oxidação. Conforme já comentado anteriormente, a complexação por substâncias orgânicas, aumenta a solubilidade e mobilidade deste elemento, possibilitando a sua 
oxidação. Para que esta reação aconteça, é necessário que o $\mathrm{Cr}$ (III) organicamente complexado, forme um complexo com o óxido de manganês do solo. Evidências da ocorrência deste mecanismo foram apresentadas por James \& Bartlett (1983b), que observaram uma oxidação de $3,5 \%$ do $\mathrm{Cr}$ (III) complexado com citrato adicionado ao solo, após doze dias de incubação. A oxidação apesar de ocorrer em menor escala, em relação à verificada para formas inorgânicas do metal, prolongou-se por um periodo muito maior, uma vez que o complexo formado permanece na forma solúvel por longos períodos.

A formação de $\operatorname{Cr}(\mathrm{VI})$ no solo, após a aplicação de resíduo de curtume, foi verificada por James \& Bartlett (1983b), mesmo ante a presença de altos níveis de redutores orgânicos presentes nestes resíduos. As quantidades de $\mathrm{Cr}$ (III) oxidado foram maiores nos tratamentos que receberam citrato, indicando que ele aumentou a solubilidade do metal, que nestes resíduos, está presente em formas insolúveis ou complexado com as proteínas do tecido cutâneo, formando complexos de alto peso molecular.

Segundo Bartlett \& James (1988), a formação de Cr(VI), pela aplicação destes resíduos ao solo, pode ocorrer em condições ótimas de oxidação. Entretanto, em virtude da natureza dos constituintes presentes, esta formação ocorrerá de forma lenta e em pequenas quantidades, impedindo que a água subterrânea seja impactada. Desta forma os níveis de $\mathrm{Cr}(\mathrm{VI})$ liberados no ambiente, proporcionariam uma fonte controlada de liberação deste elemento para as plantas, aumentando a disponibilidade de $\mathrm{Cr}$ (III) para as necessidades nutricionais de homens e animais.

A aplicação de $100 \mathrm{mg} \cdot \mathrm{kg}^{-1}$ de $\mathrm{Cr}(\mathrm{III})$ na forma de $\mathrm{CrCl}_{3}$, em conjunto com níveis crescentes de lodo de curtume, resultou em uma formação decrescente de $\mathrm{Cr}(\mathrm{VI})$, de forma inversa à variação da dose de lodo aplicada. Esta foi a constatação feita por Trebien (1994), demonstrando existir uma relação inversa entre a velocidade de reação de oxidação do $\mathrm{Cr}$ (III) e o teor de matéria orgânica do solo ou a adição de compostos orgânicos. Concluem que, a dissolução redutiva de óxidos de $\mathrm{Mn}$ ou a 
complexação do $\mathrm{Cr}$ (III) pelos compostos orgânicos são os mecanismos que atuam na inibição observada. Os autores não realizaram tratamento onde se aplicou como fonte de crômio, apenas o resíduo de curtume.

\subsubsection{Crômio (VI) no solo}

O crômio haxavalente é a forma do metal mais estável em equilíbrio com o oxigênio atmosférico, em ambientes predominantemente oxidantes. Está presente no solo como ânion, possuindo uma maior mobilidade e biodisponibilidade quando comparado ao $\mathrm{Cr}(\mathrm{III})$, penetrando facilmente através das membranas celulares de plantas e animais e sendo muito tóxico às suas células por sua natureza oxidante muito forte.

As espécies de $\mathrm{Cr}(\mathrm{VI})$ encontradas no ambiente são as formas de monohidrogeno cromato, $\mathrm{HCrO}_{4}{ }^{-}$e cromato, $\mathrm{CrO}_{4}{ }^{2-}$. A primeira forma predomina entre um $\mathrm{pH}$ de 0,9 e 6,5 e a segunda, acima de $\mathrm{pH}$ 6,5. Em ambiente ácido e concentrações maiores do que $10 \mathrm{mmol} . \mathrm{L}^{-1}$, o $\mathrm{HCrO}_{4}^{-}$pode ser polimerizado e formar dicromato, $\mathrm{Cr}_{2} \mathrm{O}_{7}^{2-}$ (Palmer \& Wittbrodt, 1991).

No ambiente, o $\operatorname{Cr}(\mathrm{VI})$ adicionado ou formado no solo poderá ser adsorvido, lixiviado, precipitado, reduzido ou consumido por organismos vivos (Bartlett \& James, 1988).

\subsection{Adsorção e precipitação}

Estando presente no meio-ambiente sempre na forma de ânion, a adsorção do $\mathrm{Cr}(\mathrm{VI})$ estará condicionada à presença de uma rede de cargas positivas nos colóides desenvolvida, principalmente, pelos óxidos de $\mathrm{Fe}$ ou $\mathrm{Al}$, minerais muito comuns em nossos solos. 
$\mathrm{O}$ pH é um fator determinante na adsorção do $\mathrm{Cr}(\mathrm{VI})$ no solo, estabelecendo a forma de $\mathrm{Cr}(\mathrm{VI})$ presente na solução e a carga predominante na superfície dos colóides. A forma hexavalente $\mathrm{Cr}_{2} \mathrm{O}_{7}{ }^{2-}$, pode ser adsorvida de forma semelhante ao ânion sulfato $\left(\mathrm{SO}_{4}{ }^{2-}\right)$ e o $\mathrm{HPO}_{4}{ }^{2-}$, formando um complexo bidentado com os minerais que apresentam cargas positivas em sua superfície. ${\mathrm{O} \mathrm{HCrO}_{4}}^{-}$, de acordo com os colóides presentes, pode estar ligado fortemente ao solo, de forma similar ao $\mathrm{H}_{2} \mathrm{PO}_{4}{ }^{-}$ou mesmo levemente retido, como o $\mathrm{HCO}_{3}^{-}, \mathrm{Cl}^{-}$e $\mathrm{NO}_{3}^{-}$(Bartlett \& James, 1988).

A adsorção do $\mathrm{Cr}$ (VI) aumenta, conforme diminui o pH do solo (James \& Bartlett 1983c, Mesuere \& Fish 1992a, Mesuere \& Fish 1992b, Zachara et al. 1989).

Mesuere \& Fish (1992a) observaram uma adsorção de Cr(VI) pela goetita que variou entre 0 e $100 \%$ do aplicado. A adsorção foi máxima quando o $\mathrm{pH}$ foi menor ou igual a 4,0. A possibilidade de ter ocorrido uma redução do $\mathrm{Cr}(\mathrm{VI})$ e interferência nos resultados, foi descartada pela excelente correlação entre análises de $\mathrm{Cr}(\mathrm{VI})$ e Cr-total realizadas.

Os óxidos cristalinos de ferro apresentaram-se como os mais eficientes na adsorção do $\mathrm{Cr}(\mathrm{VI})$. Esta adsorção foi reversível com a mudança do $\mathrm{pH}$ e menor na presença de $\mathrm{SO}_{4}{ }^{2-}$ ( James \& Bartlett 1983c, Zachara et al. 1989), carbono orgânico dissolvido( Zachara et al., 1989) e oxalato (Mesuere \& Fish, 1992b)

A adsorção acontece na superfície dos grupos hidroxilas, quando estes sofrem protonação pelo decréscimo do $\mathrm{pH}$, formando-se um complexo de superfície, segundo a seguinte reação (Rai et al., 1989).

$$
\mathrm{SOH}+\mathrm{H}^{+}+\mathrm{CrO}_{4}^{2-} \Leftrightarrow \mathrm{SOH}_{2}^{+}-\mathrm{CrO}_{4}^{2-}
$$

Zachara et al.(1989) pela aplicação do modelo FITEQL a seus dados experimentais, sugerem que o complexo de superfície formado é de esfera externa.

Fendorf (1995), cita estudo ainda não publicado, realizado por Fendorf \& Sparks, que com a utilização de análises por "Extended X-ray Absorption Fine Struture 
Spectroscopy" (EXAFS), demonstrou que o $\mathrm{Cr}(\mathrm{VI})$ forma um complexo de esfera interna com a goetita, bi e/ou monodentado. Conclue-se que o mesmo ocorra para os óxidos de alumínio hidratados.

$\mathrm{O} \mathrm{Cr}(\mathrm{VI})$ pode ser precipitado com o bário, formando $\mathrm{BaCrO}_{4}$ conforme observado por Rai et al. Citados por Rai et al. (1989). Bartlett e Kimble (1976b) verificaram que o $\mathrm{Cr}(\mathrm{VI})$ pode ser coprecipitado com o Al. Na presença de excesso de alumínio, observou-se uma completa insolubilização do $\mathrm{Cr}$ (VI) acima de pH 6,0, que retornou à forma solúvel novamente acima de $\mathrm{pH} 8,0$.

\subsection{Redução}

Sendo um agente oxidante muito forte, o $\mathrm{Cr}(\mathrm{VI})$ é reduzido à forma trivalente na presença de doadores de elétrons. No solo os mais comuns são a matéria orgânica, Fe(II) em solução e minerais de ferro.

Matéria orgânica em solução ou insolúvel são capazes de reduzir o Cr(VI), conforme observado por diversos autores (Bartlett \& Kimble, 1986b; James \& Bartlett, 1983bc; Losi et al. 1994; Wittbrodt \& Palmer, 1995)

A eficiência em reduzir o $\mathrm{Cr}(\mathrm{VI})$, está associada ao estado de decomposição da matéria orgânica. Bartlett \& Kimble (1976b) observaram que o esterco de vaca aplicado a solo pobre em matéria orgânica, reduziu apenas $2 \%$ do $\mathrm{Cr}(\mathrm{VI})$ aplicado. A redução completa ocorreu somente após o pH do solo ser diminuído de 6,0 para 3,0. Netas condições, a reação de redução foi muito rápida. Por outro lado, quando utilizaram-se solos com teores mais elevados de matéria orgânica, todo o $\mathrm{Cr}(\mathrm{VI})$ aplicado foi reduzido dentro de um período de cinco semanas, mantendo-se o $\mathrm{pH}$ natural ou mesmo elevando-o.

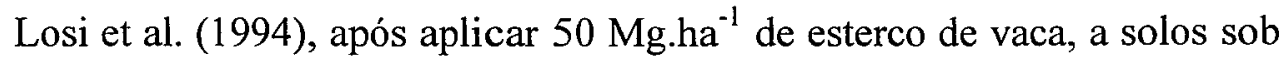
condições de esterilização ou não, demonstraram a importância da atividade microbiana na redução do $\mathrm{Cr}(\mathrm{VI})$ adicionado ao solo. Nos solos não esterilizados verificou-se uma 
redução de $96,4 \%$ do $\mathrm{Cr}(\mathrm{VI})$ aplicado, enquanto que no tratamento que sofreu esterilização a redução foi de $75 \%$. Os autores não explicam se a redução foi promovida pelos microrganismos, ou como resultado de uma maior degradação do material orgânico aplicado.

Wittbrodt \& Palmer (1995) e Bartlett \& James (1983b), realizaram experimentos onde a matéria orgânica de baixo peso molecular (ácido fúlvico e gálico), reduziu efetivamente o $\mathrm{Cr}(\mathrm{VI})$ em solução. Os primeiros autores observaram uma reação inicialmente muito rápida, que diminuía com o tempo de forma não linear, sofrendo uma influência muito forte do $\mathrm{pH}$. A reação de redução foi intensificada com o decréscimo do pH, sendo o mesmo verificado por Bartlett \& Kimble (1976b), Bloomfield \& Pruden (1980), James \& Bartlett (1983bc) e Eary \& Rai (1991).

A redução do $\mathrm{Cr}(\mathrm{VI})$ por compostos orgânicos foi seguida pela formação de um complexo solúvel, do Cr(III) originado com o novo composto orgânico, resultante da reação (James \& Bartlett, 1983b).

Eary \& Rai (1991), concluíram que o Fe(II) desempenha papel equivalente ao da matéria orgânica na redução de $\mathrm{Cr}(\mathrm{VI})$ em solos ácidos. Entretanto, onde a atividade biológica é limitada, as espécies de Fe(II) serão os principais agentes redutores do $\mathrm{Cr}(\mathrm{VI})$, conforme observou Anderson et al.(1994) para as condições moderadamente redutoras, predominantes em aquíferos arenosos.

A redução do $\mathrm{Cr}(\mathrm{VI})$ pelo $\mathrm{Fe}(\mathrm{II})$, pode ser descrita da seguinte forma:

$$
\mathrm{HCrO}_{4}^{-} \text {(aq.) }+3 \mathrm{Fe}^{2+} \text { (aq.) }+7 \mathrm{H}^{+} \Leftrightarrow \mathrm{Cr}^{3+}+3 \mathrm{Fe}^{3+}+4 \mathrm{H}_{2} \mathrm{O}
$$

Esta reação é muito rápida, com uma completa redução ocorrendo em torno de 5 min.(Fendorf \& Li, 1996; Eary \& Rai, 1988), formando-se um precipitado marrom $\left[\mathrm{Cr}_{0,25} \mathrm{Fe}_{0,75}(\mathrm{OH})_{3}\right]$, a valores de $\mathrm{pH}$ superiores a 4,0 , conforme sugerido por Eary \& Rai (1988). 
A exemplo do verificado com a matéria orgânica, o pH exerce influência marcante na intensidade de redução do $\mathrm{Cr}(\mathrm{VI})$ pelo Fe(II), conforme observado por, Eary \& Ray (1988), Eary \& Rai (1991), Fendorf \& Li (1996).

Buerge \& Hug (1997), estudando o efeito do pH na reação de redução do $\mathrm{Cr}$ (VI) pelo $\mathrm{Fe}(\mathrm{II})$, observaram uma redução maior do $\mathrm{Cr}$ (VI) abaixo de um $\mathrm{pH} 4,0$, entretanto, ao contrário do observado por outros autores, elevando-se o $\mathrm{pH}$ acima de 4,0, a velocidade de reação volta a aumentar. Nenhuma explicação foi apresentada para este fato.

Sendo uma reação onde ocorre o consumo de prótons, a redução do $\mathrm{Cr}(\mathrm{VI})$, tanto pela matéria orgânica como pelo $\mathrm{Fe}(\mathrm{II})$, é intensificada pelo aumento da concentração de $\left[\mathrm{H}^{+}\right]$, tornando-se lenta caso o pH seja elevado. Por outro lado, a diminuição do $\mathrm{pH}$ aumenta a adsorção do $\mathrm{Cr}(\mathrm{VI})$, protegendo-o de ser reduzido. Bartlett \& James (1988).

James \& Bartlett (1983c) observaram que o Cr(VI) ao ser adsorvido, não foi reduzido por ácido gálico. Esta proteção contra a redução foi ocasionada pelo complexo formado entre o $\mathrm{Cr}(\mathrm{VI})$ e os colóides responsáveis pela adsorção, que impedem a interação necessária do $\mathrm{Cr}(\mathrm{VI})$ com o agente redutor para que ocorra a transferência de elétrons.

\subsection{Nitrogênio}

Os objetivos da utilização agrícola de resíduos provenientes do tratamento de efluentes (lodos) domésticos ou industriais, são o fornecimento dos nutrientes necessários ao desenvolvimento das culturas, de matéria orgânica e correção do $\mathrm{pH}$ do solo, sem causar um aumento excessivo de elementos fitotóxicos ou bio-acumulativos (metais pesados) ou que causem risco a saúde humana ou animal (organismos patogênicos) (Anglian Water Service, 1991). 
Devido ao elevado teor de nitrogênio normalmente observado nestes resíduos, este elemento é freqüentemente o fator que determina a quantidade de lodo que pode ser aplicada ao solo. Neste sentido, deve ser observado que o N-orgânico contido no lodo não é prontamente disponível para as plantas, requerendo-se um conhecimento prévio do comportamento do N-orgânico após a aplicação do lodo no solo, de forma que um planejamento seguro desta prática seja realizado. (South Carolina Department of Health and Environment Control, 1996).

\subsubsection{Mineralização do N-orgânico em resíduos}

A intensificação do uso de lodos de esgoto/industriais em áreas agrícolas e o reconhecimento do impacto da poluição de N sobre as águas subterrâneas, advindo de uma utilização não controlada, incentivou a realização de estudos preocupados em desvendar o comportamento deste elemento no solo.

O processo de mineralização do nitrogênio, é a conversão do N-orgânico para forma inorgânica. Quando mineralizado, o N-orgânico é liberado como amônio, que ao ser oxidado transforma-se em nitrato. Devido à sua alta mobilidade no solo, o nitrato desloca-se com facilidade para baixo da zona radicular, podendo atingir as águas subterrâneas. Uma concentração na água acima de $10 \mathrm{mg} . \mathrm{L}^{-1}$ de $\mathrm{NO}_{3}-\mathrm{N}$, classifica-a como imprópria para consumo humano. (COMPANHIA DE TECNOLOGIA E SANEAMENTO AMBIENTAL - CETESB, 1990).

Por outro lado, a mineralização (amonificação e nitrificação) do Norgânico contido nos lodos, é essencial para o aproveitamento destes elementos pelas plantas. O conhecimento das taxas em que estas transformações se processam, ao se aplicar resíduos no solo, é essencial para assegurar-se que a quantidade aplicada, irá disponibilizar quantidade suficiente de $\mathrm{N}$ para as plantas, sem liberar $\mathrm{NO}_{3}{ }^{-}$em excesso.

Diversos fatores influenciam a mineralização do $\mathrm{N}$ orgânico contido em lodos de estações de tratamento de efluentes, dentre eles destacam-se: tipo de solo, 
temperatura, aeração, umidade, $\mathrm{pH}$, tipo de resíduo e taxa de aplicação (Terry et al., 1981). Uma grande variação nas taxas de mineralização foi encontrada por diversos autores.

Kelling et al. (1977) em estudo realizado em campo, encontraram uma mineralização de $50 \%$ do $\mathrm{N}$ aplicado ao solo, após um período de três semanas. Uma perda acentuada de $\mathrm{N}$ foi verificada para uma taxa de aplicação superior a $30 \mathrm{Mg} \cdot \mathrm{ha}^{-1}$, não tendo sido especificado o tipo de lodo utilizado.

Para um lodo de esgoto, digerido anaerobicamente, Lindeman \& Cardenas (1984), observaram uma variação de 56 a 72\% para a mineralização total do N orgânico de acordo com o solo utilizado e a quantidade de lodo aplicada. Num balanço realizado foi encontrada uma mineralização líquida (nitrato + nitrito) variando entre $20 \mathrm{e}$ $37 \%$, sendo a diferença observada atribuída à denitrificação. Os autores concluíram que a perda total de $\mathrm{N}$-orgânico (mineralização total) superestima a quantidade de $\mathrm{N}$ disponível para as plantas, entretanto, demonstram de maneira mais realística o quanto do lodo pode estar disponível para a próxima safra. Eles concluíram que a mineralização líquida (nitrificação) foi mais influenciada pela taxa de lodo aplicada do que pelo tipo de solo.

Ao avaliarem a taxa de mineralização para 24 diferentes tipos de lodo, Parker \& Sommers (1983), encontraram uma grande influência do tipo de tratamento ao qual o lodo foi submetido. Aproximadamente, as seguintes porcentagens de mineralização foram encontradas, de acordo com o tipo de lodo: lodo ativado - 40\%, lodo primário - $25 \%$, lodo digerido anaerobicamente - $15 \%$ e lodo compostado - $8 \%$.

Garau et al. (1986), observaram que o N potencialmente mineralizável aumentou com a elevação da taxa de lodo aplicada e foi maior para os lodos resultantes de tratamento aeróbico. $\mathrm{O} \mathrm{pH}$ teve uma influência significativa, observando-se uma maior mineralização com sua elevação até a neutralidade. Essa observação também foi feita por Terry et al. (1981). 
Hsieh et al. (1981), não encontrou diferenças significativa na mineralização de $\mathrm{N}$ para dois níveis de umidade testados ( 0,33 e 0,06 bar), por outro lado, Terry et al. (1981) observou uma nitrificação mais rápida em solos onde a umidade encontrava-se ajustada a 0,25 e 0,50 bar de tensão do que a 1 bar.

Os ensaios de mineralização realizados em laboratório, mostraram-se adequados para estimar o potencial de mineralização do $\mathrm{N}$ em condições de campo. Magdoff \& Amadon (1980) encontraram uma mineralização de 54\% em ensaio realizado em laboratório e de 55\% em campo.

Dois procedimentos experimentais de laboratório (incubação) são normalmente utilizados na investigação do N-orgânico potencialmente mineralizável em lodos de esgoto/industriais, ou seja: a) incubação do solo com o lodo e lixiviação periódica do $\mathrm{N}$ mineralizado, com solução diluída de $\left.\mathrm{KCl}\left(0,01 \mathrm{~mol} . \mathrm{L}^{-1}\right) ; \mathrm{b}\right)$ incubação do solo com o lodo e determinação do $\mathrm{N}$ mineralizado, em sub-amostras de solo coletadas periodicamente.

Parker \& Sommers (1983), compararam estes dois métodos e observaram que a mineralização do $\mathrm{N}$ no processo sem lixiviação, foi maior. Em média, para 24 diferentes lodos estudados, a mineralização do N-orgânico observada foi de $17 \%$ sem lixiviação e $16 \%$ com lixiviação, entretanto, dependendo do lodo as diferenças entre os dois procedimentos foi mais acentuada, ou, em alguns casos, invertida. A eliminação inicial de $\mathrm{N}$-orgânico solúvel potencialmente mineralizável, no procedimento com lixiviação ( $>25 \%$ do $\mathrm{N}$ lixiviado em alguns casos), foi a causa das diferenças observadas. Por outro lado, o processo com lixiviação, apresentou uma melhor concordância entre os dados obtidos e ajustados, além de ser mais aproximado dos fenômenos que ocorrem em condições de campo.

A perda de N-orgânico pela lixiviação não foi considerada importante por Lindemann \& Cardenas(1984), que observaram durante as duas primeiras semanas de incubação uma perda de 1 a $2 \mu \mathrm{g} \cdot \mathrm{mgg}^{-1}$ e, em alguns casos, menor que estes valores. 
Garau et al. (1986) observaram comportamento oposto ao relatado para os dois procedimentos. A mineralização encontrada para o processo com lixiviação $(43,0 \%)$, foi quase duas vezes maior em relação ao não lixiviado $(27,7 \%)$. Segundo os autores, a lixiviação do $\mathrm{N}$ mineralizado e sua retirada do sistema, representa melhor as condições encontradas em condições de campo, simulando a absorção deste elemento pelas plantas e as perdas por lixiviação profunda. $\mathrm{O}$ acúmulo de $\mathrm{N}$-inorgânico que ocorre no processo sem lixiviação, aumenta a probabilidade de ocorrer denitrificação e imobilização, além de, conforme salientado por Standford \& Smith (1972), causar efeitos inibitórios à mineralização, como o abaixamento do $\mathrm{pH}$ do solo, resultante da nitrificação.

\subsubsection{Efeito do crômio na mineralização do nitrogênio}

A presença de determinadas substâncias nos lodos de esgoto e industriais, ou mesmo, o seu acúmulo no solo resultante da aplicação constante de lodo, podem resultar em uma resistência anômala à degradação destes resíduos e, conseqüentemente, a uma mineralização lenta.

$\mathrm{O}$ efeito de metais pesados na mineralização do $\mathrm{N}$-orgânico foi investigada por diversos autores (Chang \& Broadbent, 1982; Dar \& Mishra, 1994; James \& Bartlett, 1984; Liang \& Tabatai, 1977 e 1978; Rother et al., 1982).

Liang \& Tabatai (1978) investigaram a influência de dezenove elementos traços no processo de nitrificação em solos. A inibição verificada foi muito variável, estando o $\mathrm{Cr}$ (III) dentro do grupo que diminui a nitrificação em mais de $50 \%$. Mais especificamente, a adição de $5 \mu$ moles de $\mathrm{CrCl}_{3}$ por grama de solo, inibiu a nitrificação em até 96, 87 e 59\%, dependendo do solo estudado, após um período de incubação de dez dias, os autores não fizeram nenhum comentário da variação observada. Em seu estudo anterior, os mesmos autores haviam observado uma inibição menor (máximo de $39 \%$ ), para a mesma concentração do elemento no solo, entretanto, o período de 
incubação foi de vinte dias. Nenhuma determinação de $\operatorname{Cr}(\mathrm{VI})$ foi realizada, entretanto, os solos foram secos ao ar antes de serem utilizados, diminuindo a chance de formação desta forma do metal, conforme verificado por Bartlett \& Kimble (1976).

Chang \& Broadbent (1982), em solo tratado com lodo de esgoto $\left(10\right.$ g.kg $\left.{ }^{-1}\right)$, alfafa $\left(10 \mathrm{~g} \cdot \mathrm{kg}^{-1}\right)$ e $100 \mathrm{mg} \cdot \mathrm{kg}^{-1}$ de $\left(\mathrm{NH}_{4}\right)_{2} \mathrm{SO}_{4}$, observaram uma inibição acentuada na imobilização, mineralização e nitrificação do nitrogênio, após a aplicação de uma dose máxima de $400 \mathrm{mg} \cdot \mathrm{kg}^{-1}$ de $\mathrm{CrCl}_{3}$. Após um período de incubação de doze semanas, para a dose maior de crômio aplicada, observou-se uma inibição na formação de nitrato da ordem de $90 \%$, superior a cinco outros metais avaliados ( $\mathrm{Cd}, \mathrm{Cu}, \mathrm{Zn}, \mathrm{Mn}$ e $\mathrm{Pb})$.

Utilizando solo com potencial para oxidar Cr(III), James \& Bartlett (1984), estudaram a influência deste metal na nitrificação do nitrogênio. O crômio foi aplicado como $\mathrm{CrK}\left(\mathrm{SO}_{4}\right)_{2}, \mathrm{~K}_{2} \mathrm{Cr}_{2} \mathrm{O}_{7}$, lodo de esgoto (63 g.kg ${ }^{-1}$ de crômio) e efluente de curtume $\left(1,7 \mathrm{~g} \cdot \mathrm{kg}^{-1}\right.$ de crômio).

A formação de nitrato foi inibida pelos tratamentos que receberam 1000 $\mu$ mol. $\mathrm{kg}^{-1}$ de $\mathrm{Cr}$ (III) ou Cr(VI), durante os primeiros 23 dias de incubação e foi menor no tratamento que recebeu a forma hexavalente. Foi observada a formação de $63 \mu \mathrm{mol} . \mathrm{kg}^{-1}$ de $\mathrm{Cr}(\mathrm{VI})$, no tratamento que recebeu $\mathrm{Cr}(\mathrm{III})$. Devido à redução do $\mathrm{Cr}(\mathrm{VI})$, formado e aplicado, ao longo do período de incubação, após 42 dias a quantidade de $\mathrm{NO}_{3}{ }^{-}$formada, foi igual para todos os tratamentos. Não foi observado efeito inibitório para a formação de nitrato, nos tratamentos que receberam efluente de curtume e lodo de esgoto. Os autores atribuíram a inibição inicial na formação de nitrato à presença de $\mathrm{Cr}(\mathrm{VI}) \mathrm{em}$ solução.

Ross et al.(1981), observaram que os dois estados de oxidação do crômio afetaram a atividade microbiana no solo.Uma concentração de $10 \mathrm{mg} \cdot \mathrm{kg}^{-1} \mathrm{Cr}(\mathrm{VI})$ e 100 mg.kg ${ }^{-1}$ de $\mathrm{Cr}(\mathrm{III})$ causaram uma diminuição na produção de $\mathrm{CO}_{2}$ de microrganismos no solo. O efeito "curtente" do $\mathrm{Cr}(\mathrm{III})$ e a toxicidade do $\mathrm{Cr}(\mathrm{VI})$ foram os responsáveis, segundo os autores, pela inibição da atividade microbiana verificada. 
A diferença observada entre a mineralização do $\mathrm{N}$, presente em um lodo de esgoto de origem doméstica e outro com grande contribuição de curtumes, foi pequena $(24,5$ e $20,0 \%)$ (Wiseman \& Zibilske, 1988). Concluiu-se não ter ocorrido inibição à população microbiana nitrificadora, pois a concentração de $\mathrm{NH}_{4}{ }^{+}-\mathrm{N}$ encontrada foi muito baixa nos dois tratamentos. A diferença encontrada, provavelmente, foi devida à presença de compostos recalcitrantes.

Sendo o pH do solo um fator importante na mineralização do N-orgânico, convém ressaltar que nenhum dos autores monitorou este parâmetro nos estudos anteriormente citados. Uma vez que a hidrolização do $\mathrm{Cr}$ (III) leva a uma diminuição do $\mathrm{pH}$, uma parte dos efeitos observados pode ter sido influenciada por este fato. 


\title{
3. POTENCIAL DE MINERALIZAÇÃO DO NITROGÊNIO DE LODOS DE CURTUME ADICIONADOS A DOIS LATOSSOLOS
}

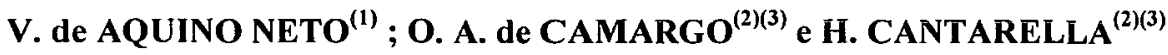

\section{RESUMO}

A utilização de lodos de curtúme em áreas agrícolas pode ser uma alternativa eficiente no tratamento e reciclagem destes resíduos devido ao seu elevado teor de nitrogênio, Neste sentido, conduziu-se um experimento, em laboratório, com o objetivo de estudar a dinâmica da mineralização do N-orgânico contido nestes resíduos e a influência do Cr(III) nesta transformação. Dois latossolos, latossolo roxo, unidade Ribeirão Preto e latossolo vermelho-amarelo unidade Laranja Azeda, receberam três doses, de dois diferentes lodos gerados no tratamento de efluentes do curtume Podboi, localizado em Leme-SP. Um lodo do efluente de caleiro (LCL) sem crômio (doses equivalentes a 10 ,

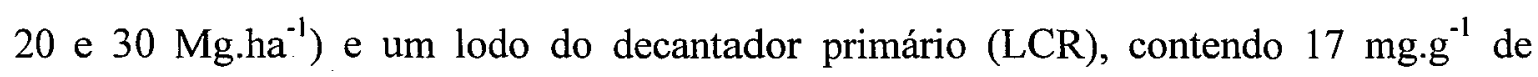

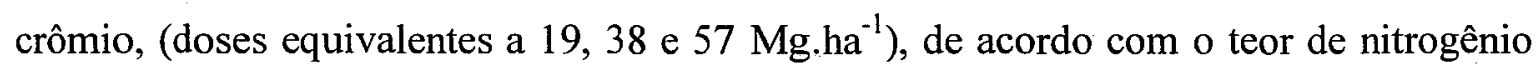
total de cada um. Duplicatas de $40 \mathrm{~g}$ das misturas solo+lodo, acrescidas de $20 \mathrm{~g}$ de esferas de vidro ( diâmetro de $2 \mathrm{~mm}$ ), foram transferidas para tubos de percolação, sendo

\footnotetext{
(1) Engenheiro Agrônomo da CETESB, Av. Prof. Frederico Hermann Jr., 345, 05489-900, São Paulo (SP).

(2) Pesquisador Científico do Instituto Agronômico, Caixa Postal 28, 13001-970, Campinas (SP).

(3) Com bolsa de Pesquisa do CNPq
} 
sendo lixiviadas após $0,7,14,34,48,62,77,90,104,118$ e 132 dias de incubação com $200 \mathrm{ml}$ de solução $0,01 \mathrm{~mol} . \mathrm{L}^{-1}$ de $\mathrm{KCl}$, determinando-se a concentração de $\mathrm{NH}_{4}^{+}$e $\mathrm{NO}_{3}^{-}$ no percolado. O nitrogênio potencialmente mineralizável (No) e a constante da taxa de mineralização $(\mathrm{k})$, foram estimados por meio de um método estatístico, não linear, de quadrados mínimos, modelando o $\mathrm{Nm}$ (nitrogênio mineralizado), de acordo com uma equação exponencial simples, assumindo-se uma reação cinética de primeira ordem. $\mathrm{O}$ processo de mineralização sofreu grande influência com a presença de crômio e em menor escala, com as taxas de aplicação e tipo de solo, em ordem decrescente. Ao longo de 132 dias de incubação o solo tratado com LCL apresentou uma mineralização líquida ao redor de $35 \%$ do total de $\mathrm{N}$ aplicado, enquanto que para o LCR, em média apenas $4,8 \%$ do total foi mineralizado. A constante da taxa de mineralização do $N$ variou entre 0,026 a $0,036 \mathrm{dia}^{-1}$ com uma média de $0,028 \mathrm{dia}^{-1}$ para o LCL enquanto que para o LCR foi, em média, da ordem de $0,0048 \mathrm{dia}^{-1}\left(0,0024\right.$ a $\left.0,0069 \mathrm{dia}^{-1}\right)$. O No aumentou com o aumento da taxa de aplicação e foi maior para o LCL do que para o LCR, entretanto, as diferenças foram menores quando comparadas com as verificadas entre os valores experimentais de $\mathrm{N}$ mineralizado. $\mathrm{O}$ aproveitamento agrícola, como fonte de $\mathrm{N}$, do lodo contendo elevados teores de crômio, fica limitado.

Termos de indexação: Nitrogênio, curtume, crômio, mineralização, lodo.

SUMMARY: Nitrogen mineralization potential of tannery sludge added to two Oxisols

The use of tannery sludge in soil may be an option to recycle these wastes due to the high nitrogen content. Therefore a laboratory experiment was carried out with the objective of studying the mineralization of the organic $\mathrm{N}$ of those wastes and the effects of $\mathrm{Cr}$ (III) on this process.Two oxissols, a Typic Eutrorthox (LRe) and a Typic Haplorthox (LVA) were treated with two different types of tannery wastes (Podboi Tannery), one with $17 \mathrm{mg}^{-1} \mathrm{~g}^{-1}$ of chromium (primary sludge - LCR) and the other without 


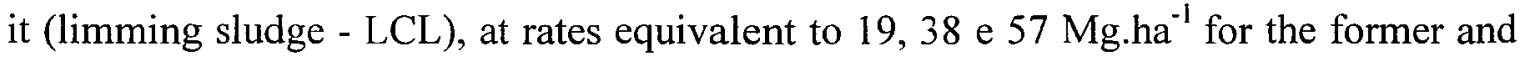
10,20 e $30 \mathrm{Mg}^{-1} \mathrm{ha}^{-1}$ for the latter in accordance with the nitrogen contents of the materials. Duplicate samples containing $40 \mathrm{~g}$ of the soil-sludge mixture plus $20 \mathrm{~g}$ of $2 \mathrm{~mm}$ glass marbles, were placed in percolation tubes wich were leached with $200 \mathrm{ml}$ of a 0.01 mol. $\mathrm{L}^{-1}$ solution of $\mathrm{KCl}$ after $0,7,14,34,48,62,77,90,104,118$ and 132 days of incubation. Ammonium and nitrate- $\mathrm{N}$ were determined in the $\mathrm{KCl}$ extract. Potentially mineralizable $\mathrm{N}\left(\mathrm{N}_{0}\right)$ and mineralizable rate constant $(\mathrm{k})$ were estimated by a non linear least square procedures fitting data of actual mineralized $\mathrm{N}(\mathrm{Nm})$ according with a simple exponential equation, assuming a first order kinetics model. Nitrogen mineralization of the sludge-treated soils was greatly affected by the presence of $\mathrm{Cr}$ and in a less extent by the application rate and soil type. Soil treated with the LCL sludge presented a net mineralization of about $35 \%$ of the total $\mathrm{N}$ applied whereas for the LCR sludge mineralization reached an average of $4,8 \%$ of the total $N$. Values of mineralization rate constant varied from 0.026 to $0.036 \mathrm{day}^{-1}$ with an average of 0.028

day $^{-1}$ for the LCL and 0.0048 day $^{-1}$ for the LCR $\left(0.0024\right.$ to 0.0069 day $\left.^{-1}\right)$. Values $\mathrm{N}_{0}$ increased with the increasing rates of sludge applied and were greater for the LCL than for the LCR; however, the differences of $\mathrm{N}_{0}$ due the type of sludge were lower than those obtained for the actual $\mathrm{N}$ mineralized. The results indicate that the agricultural use of the sludge containing high $\mathrm{Cr}$ content is of limited value as a source of $\mathrm{N}$.

\section{INTRODUÇÃO}

A reciclagem de resíduos gerados no tratamento de efluentes domésticos ou industriais (lodos), em áreas agrícolas, é considerada uma alternativa promissora e cada vez mais adotada. Os lodos gerados pela indústria do couro possuem um elevado valor como fertilizante e corretivo do solo (Hemphil et al., 1985; Stomberg et al., 1984). Por outro lado, podem apresentar elevadas concentrações de $\mathrm{Cr}(\mathrm{III})$, que não só podem 
limitar sua aplicação mas, também, interferir na disponibilidade de outros compostos, como o nitrogênio.

Devido ao elevado teor de nitrogênio, normalmente observado nestes resíduos, este elemento é, freqüentemente, o parâmetro que determina a quantidade de lodo a ser aplicada ao solo. Para um planejamento seguro desta prática, é necessário um conhecimento prévio da dinâmica da mineralização do $\mathrm{N}$-orgânico, assegurando-se que a quantidade aplicada, disponibilize uma quantidade suficiente de $\mathrm{N}$ para as plantas, sem liberar $\mathrm{NO}_{3}{ }^{-}$em excesso que, ao lixiviar-se, altere a qualidade das águas subterrâneas. Uma concentração na água acima de $10 \mathrm{mg} \cdot \mathrm{L}^{-1}$ de $\mathrm{N}-\mathrm{NO}_{3}$, classifica-a como imprópria para consumo humano (CETESB, 1990).

A mineralização do $\mathrm{N}$ presente em lodos de esgoto foi estudada por diversos autores e os resultados encontrados variaram muito ( 3,0 a 72,0\% ), de acordo com o tipo de lodo (Parker \& Sommers, 1983; Garau et al., 1986; Hsieh et al. 1981), taxa de aplicação (Lindeman \& Cardenas, 1984; Garau et al., 1986), tipo e características do solo (Lindeman \& Cardenas, 1984; Garau et al., 1986; Terry et al., 1981; Hsieh et al. 1981) e procedimento experimental (Parker \& Sommers, 1983; Garau et al., 1986).

A utilização agrícola de lodos com elevado teor de metais pesados pode aumentar substancialmente a concentração destes elementos no solo. Este acúmulo pode interferir na atividade microbiana e, conseqüentemente, na mineralização do N. O efeito de metais pesados na mineralização do $\mathrm{N}$ orgânico foi investigada por diversos autores ( Chang \& Broadbent, 1982; Dar \& Mishra, 1994; James \& Bartlett, 1984; Liang \& Tabatabai, 1977 e 1978; Rother et al., 1982 ).

Ross et al.(1981) observaram diminuição na produção de $\mathrm{CO}_{2}$ por microrganismos, ao aplicarem ao solo $\mathrm{Cr}(\mathrm{III})$ na dose de $100 \mathrm{mg} \cdot \mathrm{kg}^{-1}$ e $\mathrm{Cr}(\mathrm{VI})$ na dose de $10 \mathrm{mg} \cdot \mathrm{kg}^{-1}$.

Liang \& Tabatabai (1978) investigaram a influência de dezenove elementos traços no processo de nitrificação em solos. A adição ao solo de $5 \mu \mathrm{mol.g}{ }^{-1} \mathrm{de}$ $\mathrm{CrCl}_{3}$ inibiu a nitrificação em 96,87 e $59 \%$, dependendo do solo estudado, após um 
período de incubação de dez dias. Em estudo anterior. esses autores haviam observado uma inibição menor (máximo de 39\%), para a mesma concentração do elemento no solo, entretanto, o período de incubação usado foi de vinte dias. (Liang \& Tabatabai, 1977).

Chang \& Broadbent (1982), em solo tratado com lodo de esgoto (10 g.kg $\left.{ }^{-1}\right)$, alfafa $\left(10\right.$ g. $\left.\mathrm{kg}^{-1}\right)$ e $100 \mathrm{mg} \cdot \mathrm{kg}^{-1}$ de $\left(\mathrm{NH}_{4}\right)_{2} \mathrm{SO}_{4}$, observaram uma inibição acentuada na imobilização, mineralização e nitrificação do nitrogênio, após a aplicação de uma dose máxima de $400 \mathrm{mg} \cdot \mathrm{kg}^{-1}$ de $\mathrm{CrCl}_{3}$. Após um período de incubação de doze semanas, para a dose maior de crômio aplicada, observou-se inibição na formação de nitrato da ordem de $90 \%$, superior à observada com cinco outros metais avaliados $(\mathrm{Cd}$, $\mathrm{Cu}, \mathrm{Zn}, \mathrm{Mn}$ e $\mathrm{Pb}$ ).

Apesar de não ter sido aplicado ao solo, a possibilidade de formação de $\mathrm{Cr}(\mathrm{VI})$ pela oxidação da forma trivalente não foi monitorada nos trabalhos citados. Deve ser ressaltado, entretanto, que ao secar o solo antes da sua utilização, os autores afetaram sensivelmente a sua capacidade em oxidar o $\mathrm{Cr}(\mathrm{III})$, conforme constatado por Bartlett $\&$ Kimble (1976).

Utilizando solo com potencial para oxidar Cr(III), James \& Bartlett (1984), observaram uma inibição na formação de nitrato ao serem adicionados 1000 $\mu$ mol. $\mathrm{kg}^{-1}$ de $\mathrm{Cr}(\mathrm{III})$ ou $\mathrm{Cr}(\mathrm{VI})$, ao solo. Esta inibição ocorreu durante os primeiros 23 dias de incubação e foi maior no tratamento que recebeu a forma hexavalente. Foi observada a formação de $63 \mu$ mol. $\mathrm{kg}^{-1}$ de $\mathrm{Cr}(\mathrm{VI})$, no tratamento que recebeu $\mathrm{Cr}$ (III). Após 42 dias de incubação, a quantidade de $\mathrm{NO}_{3}^{-}$formada igualou-se para todos os tratamentos, segundo os autores, devido à redução do $\mathrm{Cr}(\mathrm{VI})$. Não foi observado efeito inibitório à formação de nitrato, ao adicionar-se ao solo efluente de curtume e lodo de esgoto. Os autores atribuem a inibição inicial na formação de nitrato à presença de Cr(VI) em solução. Por outro lado, Wiseman \& Zibilske (1988) observaram uma diferença muito pequena entre a mineralização do $\mathrm{N}$, presente em um lodo de esgoto de origem doméstica e outro com grande contribuição de curtumes $(24,5$ e $20,0 \%)$. A diferença encontrada foi atribuída à presença de compostos recalcitrantes. 
Standford \& Smith (1972) estudaram o potencial de mineralização do N no solo, utilizando um método de incubação por tempo prolongado, onde o Nmineralizado era removido do sistema periodicamente, após lixiviação com uma solução diluída. Por meio deste procedimento pretendeu-se simular os acontecimentos normalmente verificados em condição de campo (lixiviação e absorção pelas plantas), evitando o acúmulo de substâncias, que direta ou indiretamente, possam inibir o processo de mineralização.

Nesse trabalho, introduziram o conceito do nitrogênio potencialmente mineralizável e concluíram que a mineralização do $\mathrm{N}$ segue uma reação cinética de primeira ordem. Smith et al. (1980), conseguiram melhor estimativa do valor do $\mathrm{N}$ potencialmente mineralizável $\left(\mathrm{N}_{\mathrm{o}}\right)$ e da constante da taxa de mineralização $(\mathrm{k})$, usando a seguinte equação de regressão não linear:

$\mathrm{N}_{\mathrm{m}}=\mathrm{N}_{0}-\mathrm{N}_{0} \cdot \mathrm{e}^{-\mathrm{kt}}$

onde $\mathrm{N}_{\mathrm{m}}$ é a quantidade de $\mathrm{N}$ mineralizada em um tempo $\mathrm{t}$

Esta estimativa para o cálculo de $\mathrm{N}_{0}$ foi utilizada por outros pesquisadores, que confirmaram um bom ajuste aos dados de mineralização de Norgânico adicionado ao solo (Garau et al., 1986; Griffin \& Laine, 1983; Parker \& Sommers, 1983).

O objetivo principal deste estudo foi verificar a influência na mineralização do N-orgânico contido em lodos de curtume, dos seguintes fatores: (i) presença de elevados teores de $\mathrm{Cr}(\mathrm{III})$; (ii) tipo de solo e (iii) taxa de aplicação do lodo. Secundariamente, utilizou-se o modelo proposto por Smith et al (1980) com a finalidade de estimar-se o nitrogênio potencialmente mineralizável em cada um dos tratamentos estudados. 


\section{MATERIAL E MÉTODOS}

Solos - Foram utilizadas amostras dos horizontes A de dois latossolos do Estado de São Paulo, classificados por Oliveira et al. (1979) como: latossolo roxo eutrófico, textura argilosa, unidade Ribeirão Preto - LRe, (Typic Eutrorthox), coletado na Estação Experimental de Ribeirão Preto (SP) do Instituto Agronômico e latossolo vermelho-amarelo, álico, textura média, unidade Laranja Azeda - LV-3 (Typic Haplorthox), obtido na Fazenda Campininha do Instituto Florestal em Martinho Prado (SP).

Os solos foram coletados úmidos, passados em peneira com abertura de malha de $2 \mathrm{~mm}$ e mantidos com a umidade natural em containers de PVC (200 l). Desta forma, procurou-se alterar o mínimo possível o estado de oxidação dos óxidos de $\mathrm{Mn}$ e manter a capacidade do solo em oxidar o $\mathrm{Cr}(\mathrm{III})$ (Bartlett \& James, 1980).

As amostras de solo foram caracterizadas quimicamente, determinandose: $\mathrm{pH}$ em $\mathrm{H}_{2} \mathrm{O}$ (1:1); carbono orgânico total (método Walkley-Black); capacidade de troca catiônica (CTC); manganês facilmente redutível extraído com acetato de amônio e hidroquinona, todos conforme descritos por Camargo et al. (1986); Fósforo extraído com resina e determinado colorimetricamente; cálcio, magnésio, potássio e sódio extraídos com resina, sendo os dois primeiros determinados por espectrofotometria de absorção atômica e os outros dois determinados por fotometria de chama; alumínio extraído com solução de $\mathrm{KCl} 1 \mathrm{~mol} . \mathrm{L}^{-1}$, conforme descritos por Raij et al. (1987). Os teores totais de manganês e de crômio foram determinados pelo método SW-846-3050 descrito por USEPA (1986). As amostras de solo foram caracterizadas fisicamente, determinando-se teor de argila e a umidade gravimétrica (0,1 e 0,3 bar), conforme Camargo et al. (1986). As características químicas e físicas dos solos utilizados no estudo são apresentadas no quadro 1. 
Quadro 1 Características químicas e físicas das amostras de solo estudadas

\begin{tabular}{lccc}
\hline \multirow{2}{*}{ Parâmetro } & Unidade & \multicolumn{2}{c}{ Solos } \\
\cline { 3 - 4 } & & $\begin{array}{c}\text { LV-3 - Laranja } \\
\text { Azeda }\end{array}$ & $\begin{array}{c}\text { LR - Ribeirão } \\
\text { Preto }\end{array}$ \\
\hline Carbono Orgânico Total & $\mathrm{g} \cdot \mathrm{kg}^{-1}$ & 11,6 & 14,0 \\
Mn facilmente redutível & $\mathrm{mg} \cdot \mathrm{kg}^{-1}$ & 0,00 & 191,7 \\
Mn total & $\mathrm{mg} \cdot \mathrm{kg}^{-1}$ & 41,00 & 717,0 \\
Cr. total & $\mathrm{mg} \cdot \mathrm{kg}^{-1}$ & $<0,30$ & 34,0 \\
K trocável & $\mathrm{mmol}_{\mathrm{c} \cdot \mathrm{dm}^{-3}}$ & 0,2 & 0,1 \\
Ca trocável & $\mathrm{mmol}_{\mathrm{c} \cdot \mathrm{dm}^{-3}}$ & 4,0 & 1,3 \\
Mg trocável & $\mathrm{mmol}_{\mathrm{c}} \mathrm{dm}^{-3}$ & 1,0 & 1,3 \\
Na trocável & ${\mathrm{mg} \cdot \mathrm{dm}^{-3}}^{-3}$ & 4,6 & 4,6 \\
CTC & $\mathrm{mmol}_{\mathrm{c}} \cdot \mathrm{dm}^{-3}$ & 5,2 & 8,8 \\
P-resina & $\mu \mathrm{g} \cdot \mathrm{cm}^{-3}$ & 3,0 & 24,0 \\
Argila & $\mathrm{g} \cdot \mathrm{kg}^{-1}$ & 120 & 560 \\
Silte & $\mathrm{g} \cdot \mathrm{kg}^{-1}$ & 50 & 300 \\
Areia & $\mathrm{g} \cdot \mathrm{kg}^{-1}$ & 830 & 140 \\
Ug 0,1 bar & $\mathrm{g} \cdot \mathrm{kg}^{-1}$ & 114 & 366 \\
Ug 0,3 bar & $\mathrm{g} \cdot \mathrm{kg}^{-1}$ & 94 & 335 \\
& & & \\
pH-H $\mathrm{O}(1: 1)$ & & 4,0 & 5,0 \\
\hline
\end{tabular}

Lodos - Os lodos foram coletados no Curtume Podboi, localizado em Leme, SP. Dois tipos de lodo foram amostrados: (i) lodo produzido no decantador primário (LCR), resultante da reunião de todos os efluentes gerados no processo, inclusive o da etapa de curtimento ao crômio e (ii) lodo produzido pela precipitação do efluente gerado na etapa de caleiro (LCL), realizada usando bombonas de plástico por meio do abaixamento do $\mathrm{pH}$ do efluente até 5,5, determinado por meio de JAR-teste. Após a precipitação e separação do lodo, o pH da mistura foi elevado até 8,0 novamente. Os dois lodos utilizados são brutos, não tendo sido submetidos a processos de estabilização.

Os lodos coletados foram passados em peneira com abertura de malha de $10 \mathrm{~mm}$, homogeneizados, armazenados em bombonas de polietileno de $50 \mathrm{~L}$ e mantidos em câmara fria a $4{ }^{\circ} \mathrm{C}$ ( 90 dias) até o momento de sua utilização, quando foram secos em 
estufa a $40{ }^{\circ} \mathrm{C}$, até a redução da umidade para um valor entre 70 e $80 \%$ aproximadamente. Os lodos foram caracterizados determinando-se: pH em água (1:1), nitrogênio total com modificação envolvendo ácido salicílico para incluir nitrato e nitrito. conforme descrito por Bremner (1996), umidade $\left(105^{\circ} \mathrm{C}\right)$, potássio, sódio, cálcio, magnésio, manganês, crômio totais pelo método da SW-846-3050 descrito por EPA (1986), carbono orgânico total (método Walkley-Black), conforme descrito por Camargo et al. (1986) e fósforo total pelo método de redução por ácido ascórbico, descrito no Standard Methods for the Examination of Water and Wastewater (1995). As características químicas dos lodos utilizados no estudo são apresentadas no Quadro 2 .

Quadro 2 Composição química com base na matéria seca, dos lodos de curtume utilizados.

\begin{tabular}{lcrr}
\hline & & \multicolumn{2}{c}{ Lodo } \\
\cline { 3 - 4 } \multicolumn{1}{c}{ Parâmetro } & Unidade & LCR & LCL \\
\hline & & 8,0 & 8,0 \\
pH & & 817 & 689 \\
Umidade & $\mathrm{g} \cdot \mathrm{kg}^{-1}$ & 239,3 & 240,8 \\
Carbono Orgânico total & $\mathrm{g} \cdot \mathrm{kg}^{-1}$ & 17350,0 & 60,0 \\
Crômio total & $\mathrm{mg} \cdot \mathrm{kg}^{-1}$ & 1202,8 & 59346,6 \\
Nitrogênio total & $\mathrm{m} \cdot \mathrm{kg}^{-1}$ & 310,7 & 892,4 \\
Fósforo total & $\mathrm{mg} \cdot \mathrm{kg}^{-1}$ & 1059,7 & 1920,0 \\
Potássio total & $\mathrm{mg} \cdot \mathrm{kg}^{-1}$ & 1660,0 & 66000,0 \\
Sódio total & $\mathrm{mg} \cdot \mathrm{kg}^{-1}$ & 52500,0 & 6700,0 \\
Cálcio total & $\mathrm{mg} \cdot \mathrm{kg}^{-1}$ & 872000,0 \\
Magnésio total & $\mathrm{mg} \cdot \mathrm{kg}^{-1}$ & 7540,0 & 472,8 \\
Manganês total & $\mathrm{mg} \cdot \mathrm{kg}^{-1}$ & 6350,0 & 966,0 \\
\hline
\end{tabular}

Incubação - Os lodos foram adicionados aos solos de acordo com seu teor total de N, nas doses de $0,8,2,16,4$ e 24,6 g.kg ${ }^{-1}$ de LCR e $0,4,3,8,6$ e 12,9 g.kgde LCL para o solo LRe e 0, 7,2, 14,4 e 21,6 g.kg-1 de LCR e 0, 3,8, 7,6 e 11,4 g.kg ${ }^{-1}$ de

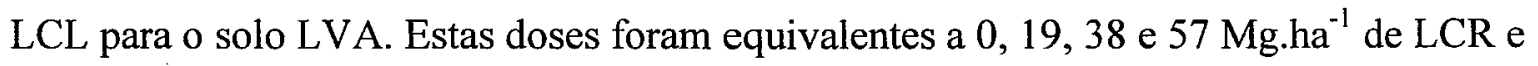
0, 10, 20, e $30 \mathrm{Mg}$.ha-1 de LCL para ambos os solos. O pH dos solos em cada tratamento 
foi ajustado a 6,5 com uma mistura de $\mathrm{CaCO}_{3}+\mathrm{MgO}(3: 1)$, com base em curva de neutralização previamente obtida pela incubação dos solos com os lodos e a mistura de carbonato de cálcio e óxido de magnésio acima.

Foram adicionadas $20 \mathrm{~g}$ de esferas de vidro (diâmetro médio $=2 \mathrm{~mm}$ ) a $40 \mathrm{~g}$ da mistura solo + lodo (base seca), para aumentar a aeração e a permeabilidade. Duplicatas de cada um dos tratamentos foram transferidas para tubo de percolação de vidro com diâmetro de 20,0 mm, contendo em sua base manta geotextil. Este mesmo material também foi colocado logo acima da superfície do solo para evitar a sua dispersão e compactação, quando a solução extratora fosse aplicada. Os tubos foram tampados com folha de papel alumínio com pequeno orifício e envoltos com cartolina preta, permitindo-se a troca gasosa, evitando a perda de umidade e impedindo o desenvolvimento de vegetais e fungos entre o solo e a parede dos tubos. $\mathrm{O}$ ensaio foi conduzido em laboratório e mantido à temperatura ambiente $\left(25-28^{\circ} \mathrm{C}\right)$.

Os tubos com a amostra foram inicialmente lixiviados, após a sua montagem, com $200 \mathrm{~mL}$ de solução $0,01 \mathrm{~mol}^{-\mathrm{L}^{-1}}$ de $\mathrm{KCl}$, em incrementos de $20 \mathrm{~mL}$, para eliminar o $\mathrm{N}$ mineral pré-existente. $\mathrm{O}$ mesmo procedimento foi realizado após 7,14 , 34, 48, 62, 77, 90, 104, 118 e 132 dias de incubação. O lixiviado coletado foi armazenado por 8 horas a $4{ }^{\circ} \mathrm{C}$ e então analisado para $\mathrm{NH}_{4}{ }^{+}$e $\mathrm{NO}_{3}{ }^{-}+\mathrm{NO}_{2}{ }^{-}$por destilação a vapor com $\mathrm{MgO}$ e liga de Devarda (Bremner \& Keeney, 1966). O excesso de solução foi eliminado a vácuo $(0,067 \mathrm{MPa})$, mantendo uma condição de aerobiose durante a incubação.

Análise Estatística - Os dados foram interpretados usando-se uma análise da variância para um arranjo fatorial dos três fatores de tratamento e seus níveis (dois solos, dois tipos de lodos e quatro doses de lodo).

A estimativa do nitrogênio mineralizável foi realizada assumindo-se que a mineralização segue uma reação cinética de primeira ordem ( Standford \& Smith, 1972), descrita por: 
$\mathrm{dN} / \mathrm{dt}=-\mathrm{kN}$

onde $\mathrm{N}$ é o nitrogênio mineralizado, $\mathrm{k}$ é a constante da taxa de mineralização e $\mathrm{t}$ é o tempo.

Desta forma, optou-se pela utilização do modelo proposto por Smith et al (1980), baseado em uma equação de regressão exponencial simples:

$\mathrm{N}_{\mathrm{m}}=\mathrm{N}_{0}-\mathrm{N}_{0} \cdot \mathrm{e}^{-\mathrm{kt}}$

onde : $\mathrm{Nm}$ é o nitrogênio total mineralizado no tempo $\mathrm{t}$ e $\mathrm{N}_{0}$ é o nitrogênio potencialmente mineralizável.

Os dados de mineralização foram analisados utilizando-se o sistema de análise de regressão não linear contido no programa PlotIT, optando-se pelo método de Marquardt, recomendado por Smith et al (1980).

\section{RESULTADOS E DISCUSSÃO}

\section{Mineralização do N-orgânico}

A quantidade de nitrogênio orgânico mineralizado, acumulada nos diferentes tratamentos estudados, foi crescente com o tempo e a taxa de aplicação para os dois solos e lodos estudados. Este crescimento apresentou um comportamento exponencial assintótico em relação ao tempo (Figuras 1 e 2). O quadro 3 apresenta uma resumo da quantidade de $\mathrm{N}$ lixiviada e acumulada, ao longo do período de incubação de 132 dias. 
O lodo do caleiro (LCL) apresentou uma mineralização rápida e crescente nas cinco primeiras semanas ( 34 dias), período em que, em média, $70 \%$ da quantidade total acumulada ao longo do experimento, foi detectada no latossolo vermelho-amarelo e $61 \%$ no latossolo roxo. A partir deste ponto, a taxa de mineralização foi decaindo gradualmente. Comportamento semelhante para lodos com elevado $\mathrm{N}_{\mathrm{o}}$ foi observado por Griffin \& Lane (1983).

O mesmo comportamento não foi observado para o lodo do decantador primário (LCR), que continha elevada concentração de crômio. Neste caso a mineralização ocorreu de forma mais uniforme e lenta, como pode ser observado nas Figuras $1 \mathrm{e} 2$.

Ao longo de 132 dias de incubação o solo tratado com o lodo LCL apresentou uma mineralização líquida ao redor de $35 \%$ do $\mathrm{N}$ total aplicado, enquanto que para o LCR ( $17 \mathrm{~g} . \mathrm{kg}^{-1}$ de Cr), observou-se, em média, que apenas 4,8\% do $\mathrm{N}$ total aplicado passou à forma inorgânica com uma variação de 0 a 8,9\% (Quadro 3).

Esta constatação encontra apoio nos trabalhos realizados por Liang \& Tabatabai (1977), Liang \& Tabatabai (1978), Chang \& Broadbent (1982) e James \& Bartlett (1984), que relataram inibição do processo de mineralização ao aplicarem crômio trivalente ou hexavalente ao solo. O grau de inibição verificado e o estado de oxidação do $\mathrm{Cr}$ responsável por este fato não foram um consenso entre estes autores, entretanto, em algumas situações, o decréscimo observado pode ter sido causado por ação direta do metal sobre a população microbiana, ao ser aplicado na forma de sal inorgânico.

Nas condições deste experimento, a menor mineralização verificada no lodo com crômio deve estar relacionada à formação de complexos, de difícil degradação, entre o metal e o material orgânico, predominantemente formado de proteínas animais. Ross et al. (1981), ao observarem diminuição na produção de $\mathrm{CO}_{2}$ por microrganismos, em solos que receberam crômio trivalente (100 ing. $\mathrm{kg}^{-1}$ ), especularam que uma das possíveis causas seria o efeito "curtente" deste elemento, que une os compostos 
orgânicos, formando complexos de baixa disponibilidade como fonte de energia e que sofrem uma decomposição muito lenta no solo.

Wiseman \& Zibilske (1988) observaram diferenças menores entre a taxa de mineralização do $\mathrm{N}$ presente em um lodo de esgoto de origem doméstica e outro com grande contribuição de curtumes $(24,5$ e $20,0 \%)$. Esta diferença também foi atribuída à presença de compostos recalcitrantes. Entretanto, para o tratamento onde se aplicou uma dose equivalente a $19 \mathrm{Mg} \cdot \mathrm{ha}^{-1}$ de LCR ao solo LVA, uma quantidade de $\mathrm{N}$ mineralizado inferior ao observado para o tratamento testemunha (Figura 1), sugere que uma inibição da atividade microbiana, devido à presença do crômio, possa ter ocorrido. 


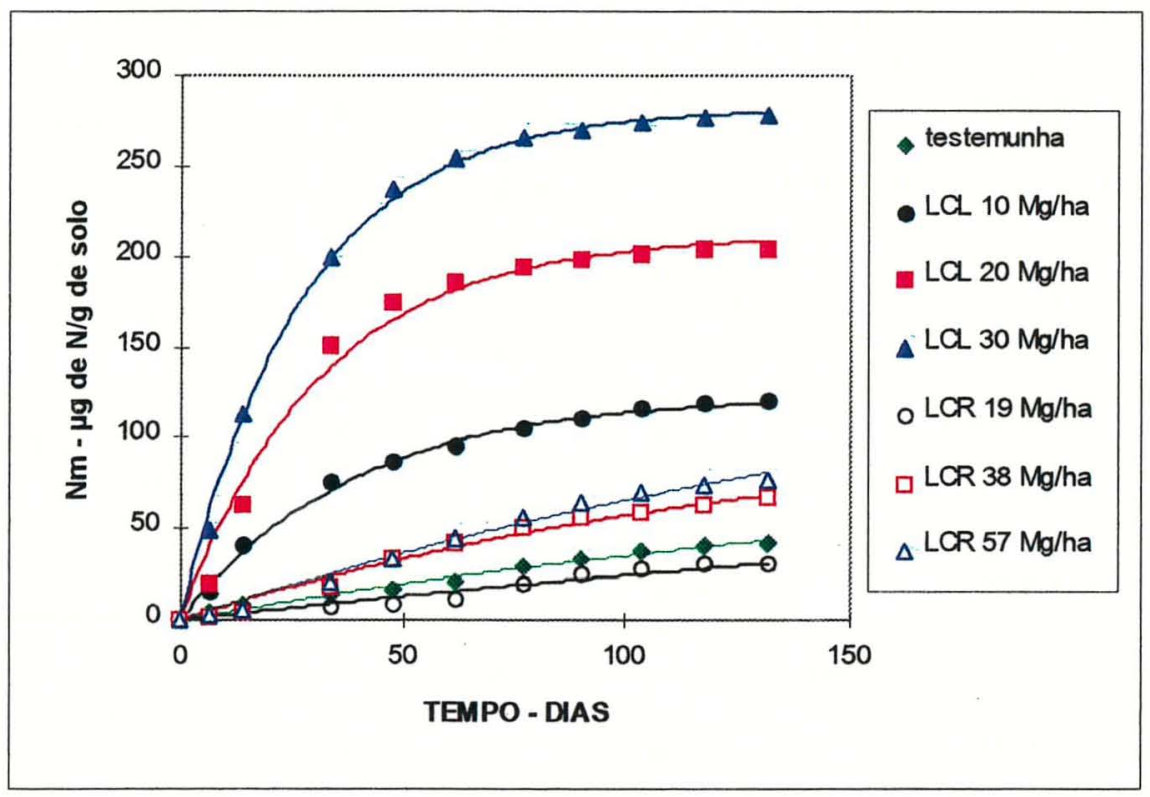

Figura 1 Nitrogênio mineralizado $(\mathrm{Nm})$ de um latossolo vermelho amarelo - unidade Laranja Azeda, tratado com lodo do caleiro LCL e lodo do decantador primário (LCR). A linha sólida foi calculada por regressão não-linear, assumindo-se uma reação cinética de $1^{\underline{a}}$ ordem.

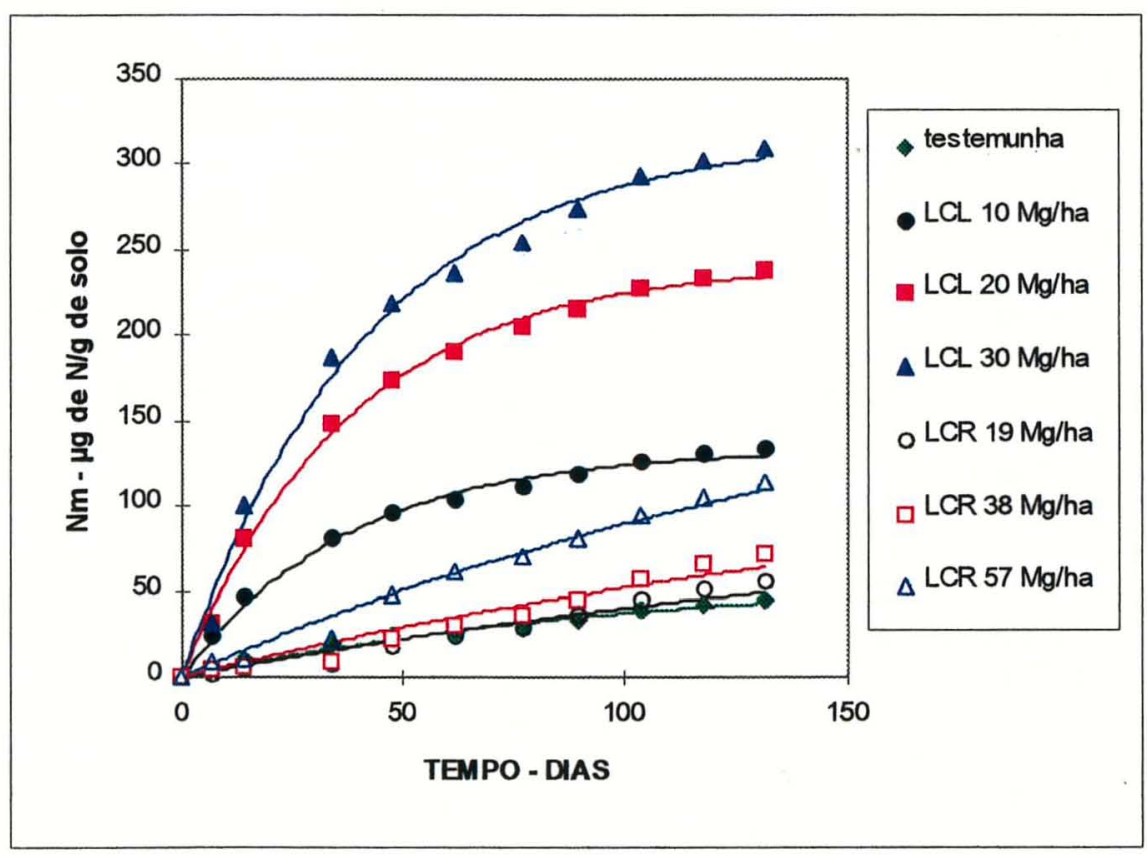

Figura 2 Nitrogênio mineralizado $(\mathrm{Nm})$ de um latossolo roxo - unidade Ribeirão Preto, tratado com lodo do caleiro LCL e lodo do decantador primário (LCR). A linha sólida foi calculada por regressão não-linear, assumindo-se uma reação cinética de $1^{\mathrm{a}}$ ordem. 
Uma análise estatística fatorial foi realizada, para determinar a influência de cada um dos fatores estudados ( tipo de solo, tipo de lodo e taxa de aplicação), na mineralização do $\mathrm{N}$-orgânico aplicado. A análise da variância foi significativa para os três fatores estudados, com o maior valor de $\mathrm{F}$ encontrado para o tipo de lodo. A única interação significativa foi entre tipo de lodo e taxa de aplicação. Observações semelhantes foram feitas por Lindeman \& Cardenas (1984), os quais verificaram que a mineralização foi dependente da taxa de lodo aplicada, mas não do tipo de solo estudado. Parker \& Sommers (1983), ao estudarem 24 diferentes tipos de lodos, concluíram que o tipo de lodo foi o fator determinante na quantidade de $\mathrm{N}$-orgânico mineralizado. Os lodos em questão foram diferenciados apenas quanto ao processo de estabilização adotado. Garau et al (1986), por outro lado, observaram que a mineralização do Norgânico contido em lodos de esgoto sofreu maior influência do tipo de solo em relação ao tipo de lodo e taxa de aplicação. Entretanto, os solos apresentavam diferenças significativas nos valores de $\mathrm{pH}$, fator determinante na transformação do nitrogênio segundo Terry et al, (1981), o que não aconteceu no presente estudo. 


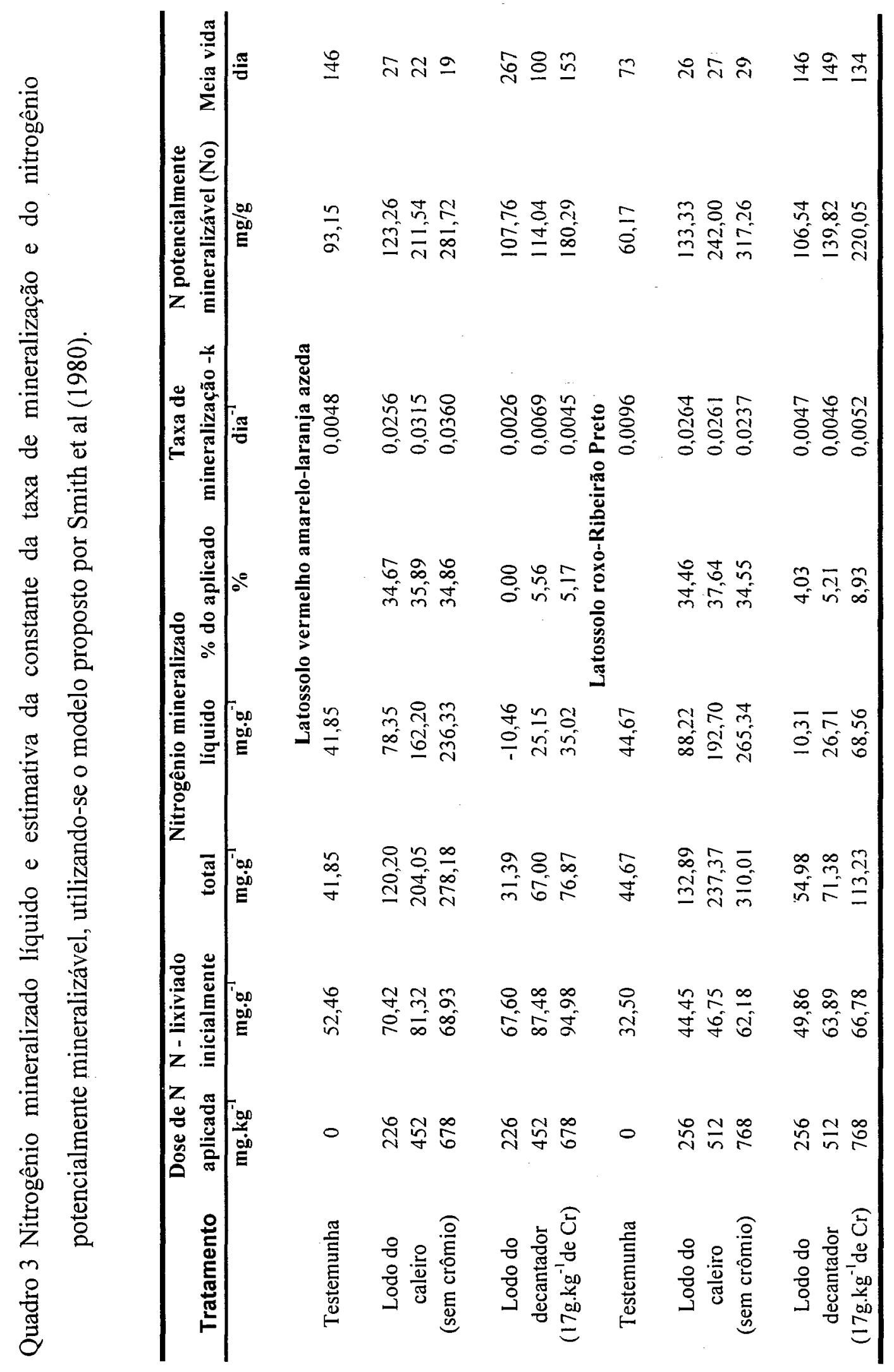




\section{Potencial de Mineralização}

As estimativas da constante da taxa de mineralização $(\mathrm{k})$ e do nitrogênio potencialmente mineralizável $\left(\mathrm{N}_{0}\right)$ conseguidos pela aplicação do modelo sugerido por Smith et al. (1980), aos dados experimentais levantados, são apresentados no quadro 3. As figuras 1 e 2 apresentam as curvas ajustadas aos dados experimentais pelo procedimento anteriormente citado.

Nos cálculos realizados neste experimento, não foram descontados os valores do $\mathrm{N}$ mineralizado na parcela controle, uma vez que a quantidade de $\mathrm{N}$ total que se mineraliza, é um parâmetro mais correto para o cálculo das taxas anuais de lodo a serem aplicadas ao solo, ao levar-se em conta as necessidades das culturas e o potencial de contaminação da água subterrânea.

Constante da taxa de mineralização - os valores de $\mathrm{k}$ variaram entre 0,026 a 0,036 $\mathrm{dia}^{-1}$ com uma média de $0,028 \mathrm{dia}^{-1}$ para o LCL, sendo mineralizado, em média, $3 \%$ do $\mathrm{N}_{0}$ por dia (Quadro 3). Valores semelhantes foram encontrados por Garau et al. (1986), Lindeman \& Cardenas (1984) e Parker \& Sommers (1983), ao avaliarem a mineralização em lodos de esgoto. Apenas para o LVA, verificou-se um aumento do k, embora de pequena magnitude, com o aumento da taxa de lodo aplicada $(0,026$ a 0,036 $\operatorname{dia}^{-1}$ ), fato não observado para o LRe. Segundo Lindeman \& Cardenas (1984), os valores de k não devem aumentar com o aumento da adição de lodo, se a mineralização seguir uma reação cinética de primeira ordem.

Os resultados do Quadro 3 indicam que para o LCR, os valores de $\mathrm{k}$ foram menores em relação ao LCL, sendo em média da ordem de $0,0048 \mathrm{dia}^{-1}$.Observase, também, uma variação acentuada nos valores deste parâmetro para o LVA $(0,0026$ a $\left.0,0069 \mathrm{dia}^{-1}\right)$, o mesmo não ocorrendo para o $\operatorname{LRe}\left(0,0024\right.$ a $\left.0,0026 \mathrm{dia}^{-1}\right)$. Entretanto, esta variação não foi diretamente proporcional ao aumento da taxa de lodo aplicada. 
Oliveira (1987) estudando 20 solos do Distrito Federal encontrou um valor médio para a constante da taxa de mineralização de 0,009 dia $^{-1}(0,036-0,005$ $\mathrm{dia}^{-1}$ ), por outro lado, os valores obtidos por Camargo (1996) ao estudar alguns solos do Rio Grande do Sul, foram maiores, em média $\left(0,042 \mathrm{dia}^{-1}\right)$, e apresentaram uma variação menos intensa $\left(0,030\right.$ a $\left.0,047 \mathrm{dia}^{-1}\right)$.

$\mathbf{N}$-potencialmente mineralizável $\left(\mathbf{N}_{\mathbf{0}}\right)$ - Os valores estimados para o $\mathrm{N}_{0}$ foram crescentes com as taxas aplicadas e sempre superiores aos dados experimentais, indicando que N-orgânico mineralizável do lodo ainda permanece no solo após as dezenove semanas de incubação estudadas (Quadro 3).

A tendência de maior mineralização do $\mathrm{LCL}$ em relação ao $\mathrm{LCR}$, foi mantida ao estimar-se o $\mathrm{N}_{0}$ que correspondeu, em média, a 47\% do $\mathrm{N}$ total aplicado para o LCL e $32 \%$ para o LCR. Entretanto, a diferença foi substancialmente menor do que aquela verificada para os dados de $\mathrm{N}$ mineralizado experimentais (35\% em média para o LCL e 4,8\% para o LCR), podendo-se concluir que o lodo com crômio, apesar de mineralizar-se mais lentamente, apresentou uma tendência de prolongar por tempo maior a fase ascendente da curva de mineralização, com uma meia vida maior (Quadro 3) ou ter sido seu $\mathrm{N}_{0}$ superestimado por possuir comportamento diferente do assumido pelo modelo aplicado. A explicação mais aceitável considera as duas hipóteses verdadeiras.

A Figura 3 refere-se à ampliação das curvas experimental e ajustada do

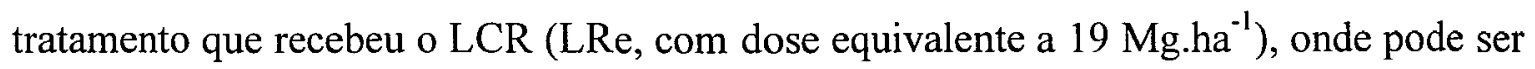
observado o ajuste inadequado conseguido entre os dados experimentais (pontos) e os estimados (linha contínua), situação verificada também nos outros tratamentos que receberam lodo com crômio. Na Figura 3 podem ser identificadas três possiveis tendências dos dados experimentais ( $\mathrm{A}, \mathrm{B}$ e $\mathrm{C}$ ) quanto à taxa de mineralização do $\mathrm{N}$, todas com comportamento cinético de primeira ordem, semelhante ao proposto por Standford \& Smith (1972). As três curvas provavelmente se referem a frações distintas 
da matéria orgânica quanto à resistência à degradação, devido à intensidade da sua interação com o crômio, formando complexos estáveis com o material de origem orgânica, dificultando a ação dos microrganismos, objetivo básico do uso do curtimento de peles animais.

As fases identificadas provavelmente devem representar adaptações sucessivas da população microbiana à estas diferentes frações recalcitrantes, adaptações estas, que vão se sucedendo ao longo do tempo pela seleção natural dos microrganismos mais eficientes na obtenção da energia disponível.

Portanto, nesta situação, o melhor ajuste aos dados experimentais seria conseguido por meio de um modelo mais complexo em relação ao proposto por Smith et al (1980) e mesmo ao proposto por Molina et al. (1980), que subdividiram o N-orgânico contido em lodos de esgoto em duas frações, uma facilmente degradável e outra recalcitratante. Para os lodos de curtume gerados na decantação primária, esta fração recalcitrante deveria ser subdividida em outras frações, com diferentes valores de taxa de mineralização.

O tempo de incubação de 132 dias foi, aparentemente, insuficiente para prever-se o comportamento real do lodo contendo crômio, o que pode ser concluído pela observação do tempo de incubação necessário para que a metade do No seja mineralizado (meia-vida), calculados a partir dos parâmetros estimados pelo modelo. (Quadro 3). Para o LCR, a meia-vida variou entre um mínimo de 100 e um máximo de 267 dias, valores muito superiores ao LCL que, em média, apresentou uma meia-vida de 25 dias, dentro de uma amplitude de variação muito menor (19 a 29 dias). Outra observação interessante foi a diferença verificada entre a meia-vida dos tratamentos testemunhas, sem adição de lodo, quando se observou para o LVA um valor de 146 dias, muito superior ao verificado para o LRe, 73 dias. Esta diferença, provavelmente, deve-se aos diferentes manejos agrícolas, de cada uma das áreas onde os solos foram coletados. O LVA foi coletado em área de reflorestamento com eucalipto, portanto, recebendo contribuição de materiais mais dificilmente degradáveis, enquanto o LRe foi coletado 
em área de pasto natural com grama. Observação semelhante foi realizada por GamaRodrigues et al (1997), ao estudarem a degradação da biomassa de carbono e nitrogênio em solos reflorestados com diferentes espécies florestais.

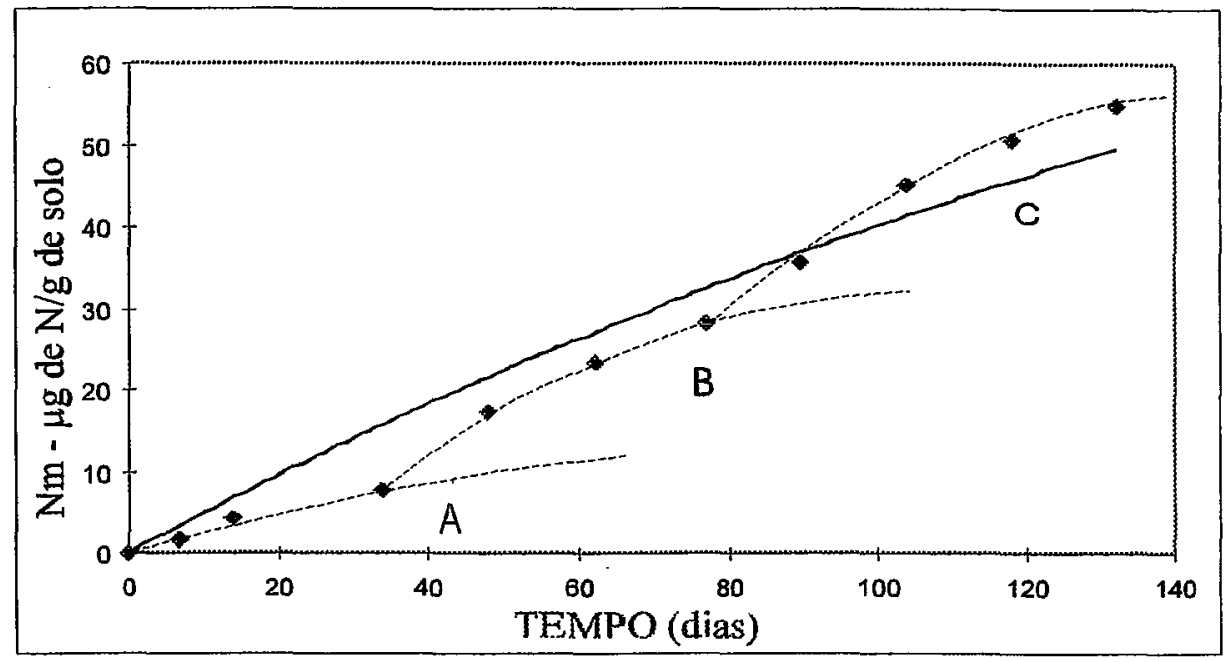

Figura 3 Curvas do $\mathrm{N}$ mineralizado $(\mathrm{Nm})$ para o latossolo roxo - unidade Ribeirão Preto, do N-orgânico oriundo da aplicação de lodo do decantador primário (LCR) na dose de $19 \mathrm{Mg} \cdot$ ha $^{-1}$. A linha sólida foi calculada por regressão nãolinear, assumindo-se uma reação cinética de $1^{2}$ ordem. As curvas identificadas pelas letras A, B e C sugerem a presença de diferentes frações de N-orgânico quanto à dificuldade de mineralização

\section{CONCLUSÕES}

1. As diferenças verificadas na mineralização entre os dois lodos de curtume estudados, lodo do caleiro (LCL) e lodo do decantador primário (LCR), permitiu concluir que a presença de elevados teores de crômio no LCR diminuiu a velocidade de mineralização do N-orgânico de maneira acentuada. Este fato limita o aproveitamento agrícola deste último à correção da acidez do solo, portanto, subaproveitando seu potencial, evidenciado pela comparação com os resultados obtidos com o LCL, que possuia baixos teores do metal. A conjunção das exigências 
seria a segregação das fontes de crômio dentro do processo de tratamento dos efluentes, gerando um lodo mais apropriado à reciclagem de nutrientes para as culturas.

2. O modelo proposto por Standford \& Smith (1972) para a mineralização de N se ajustou adequadamente aos dados experimentais obtidos para o lodo do caleiro (LCL), mas não aos dados do lodo do decantador primário (LCR), indicando que a mineralização do $\mathrm{N}$-orgânico neste caso não segue uma equação cinética de primeira ordem, ou requer um modelo mais complexo, que leve em conta as diferentes frações recalcitrantes presentes no lodo. 


\title{
4. CRESCIMENTO E ACÚMULO DE CRÔMIO EM ALFACE CULTIVADA EM DOIS LATOSSOLOS TRATADOS COM $\mathrm{CrCl}_{3} \mathrm{E}$ RESÍDUOS DE CURTUME
}

\author{
V. de Aquino Neto ${ }^{1}$; O. A. de Camargo ${ }^{2.3}$
}

\section{RESUMO}

Resíduos sólidos de curtume e $\mathrm{CrCl}_{3}$ foram aplicados a dois solos, latossolo roxo eutrófico (LRe) unidade Ribeirão Preto e latossolo vermelho-amarelo (LVA) unidade Laranja Azeda, que se diferenciaram, entre outros atributos, pelo teor de manganês facilmente redutível. Os resíduos utilizados foram lodo do efluente de caleiro sem crômio (LCL) e um lodo do decantador primário (LCR), contendo $17 \mathrm{mg} . \mathrm{g}^{-1}$ de crômio, aplicados em doses correspondentes a 10, 20 e $30 \mathrm{Mg} \mathrm{ha}^{-1}$ e 19, 38 e $57 \mathrm{Mg} \cdot \mathrm{ha}^{-1}$ (base seca), respectivamente, de acordo com o teor de nitrogênio total de cada um. $\mathrm{O} \mathrm{CrCl}_{3}$ foi aplicado nas doses de 330, 660 e $990 \mathrm{~kg} \cdot \mathrm{ha}^{-1}$ de $\mathrm{Cr}$, equivalente às doses aplicadas na forma de lodo (LCR). O experimento foi conduzido em vasos alocados em casa de vegetação, que foram monitorados quanto à formação de $\mathrm{Cr}(\mathrm{VI})$ após $1,6,14,28,54 \mathrm{e}$ 86 dias da instalação. Após o $56^{\circ}$ dia de incubação, foi transplantada para cada vaso uma

\footnotetext{
' CETESB, Av. Prof. Frederico Hermann Jr., 345, 05489-900, São Paulo (SP)

${ }^{2}$ Seção de Pedologia, Instituto Agronômico, Caixa Postal 28, 13001-970, Campinas (SP)

${ }^{3}$ Com bolsa de Pesquisa do CNPq.
} 
muda de alface (Lactuca sativa L.), cultivada por um período de trinta dias. A oxidação do $\mathrm{Cr}$ (III) foi verificada apenas para o LRe nos tratamentos que receberam doses crescentes de $\mathrm{CrCl}_{3}$, sendo máxima (0,72 a 1,16\% do aplicado) após o $1^{\circ}$ dia de incubação, decrescendo com o tempo e não sendo detectada sua presença para nenhuma das doses após o $54^{\circ}$ dia. A aplicação dos resíduos elevou a condutividade elétrica do extrato de saturação $(2: 1)\left(1,40\right.$ a 5,07 dS.m $\left.{ }^{-1}\right)$ e a $\operatorname{RAS}(3,05$ a 14,12), afetando negativamente o desenvolvimento da alface e causando a morte das plantas nas doses mais altas, sendo estes efeitos mais pronunciados no LVA. A concentração de crômio na parte aérea das plantas aumentou, nem sempre de forma proporcional, com o aumento das doses aplicadas na forma de lodo ou sal, com efeito mais acentuado para o LVA do que para o LRe. A aplicação de resíduos de curtume no experimento, para ambos os solos, mostrou-se mais limitada pelo seu conteúdo em sais do que pela presença de crômio.

Termos de indexação: curtume, lodos, crômio, crômio hexavalente, condutividade elétrica, RAS.

SUMMARY: Lettuce yield and chromium uptake in two oxissols treated with $\mathrm{CrCl}_{3}$ and tannery sludges.

Tannery solid wastes and $\mathrm{CrCl}_{3}$ were applied to two Oxissols in a greenhouse pot experiment. Soils used were Typic Eutrorthox (LRe) and Typic Haplorthox (LVA) which main difference was the manganese oxide content. The tannery wastes were sludge from the limming process without chromium (LCL) and the primary sludge (LCR) with a total chromium content of $17 \mathrm{mg} \cdot \mathrm{g}^{-1}$. The sludges were applied at three different rates taking into account it's total nitrogen content (10, 20 and $30 \mathrm{Mg}^{-h^{-1}}$ for the LCL and 19, 38 and $57 \mathrm{Mg} \cdot \mathrm{ha}^{-1}$ for the LCR, both at a dry weight basis). $\mathrm{CrCl}_{3}$ was applied at rates of 330,660 and $990 \mathrm{~kg} \cdot \mathrm{ha}^{-1}$ of chromium, equivalent to the rates 
applied of LCR sludge. $\mathrm{Cr}(\mathrm{VI})$ was measured 1, 6, 14, 28, 54 and 86 days after incubation. After 56 days a one month old lettuce seedling (Lactuca sativa L.), was planted and grown for 30 days. The $\mathrm{Cr}$ (III) oxidation was detected only at the $\mathrm{CrCl}_{3}$ treatment of the LRe soil, being the highest after the first day of incubation $(0,72$ to $1,16 \%$ of the total $\mathrm{Cr}$ applied), decreasing afterwards to non detection limits after the $54^{\text {th }}$ day. The application of both sludges increased the eletrical conductivity (1,40 to $\left.5,07 \mathrm{dS} \cdot \mathrm{m}^{-1}\right)$ and the sodium adsorption rate $(3,05$ to 14,12$)$. It affected lettuce development causing death of the plants at the highest rates. $\mathrm{LCR}$ and $\mathrm{CrCl}_{3}$ treatments increased the levels of chromium in the plant shoots but not always proportionaly with increasing rates. Both ocurrences were more pronounced for the LVA soil. Under the conditions of the experiment, salt insted of chromium concentration in the sludge limited its aplication to solo.

\section{INTRODUÇÃO}

A produção brasileira de couros inteiros curtidos de bovinos em 1992 alcançou a cifra de 22 milhões de peças, com $85 \%$ deste total sendo submetida a curtimento ao crômio segundo o Guia Brasileiro do Couro, elaborado pela Associação Brasileira de Químicos e Técnicos da Indústria do Couro - ABQTIC (1995). O Estado de São Paulo possuía nesta ocasião, 92 curtumes em operação, 25\% deles concentrados na região de Franca (SP). Straus e Silva (1980), em levantamento realizado em curtumes do Estado de São Paulo, encontraram que o tratamento dos resíduos líquidos gerados nesta atividade industrial, dá origem a resíduos sólidos ou semi-sólidos (lodos) a uma taxa estimada de cinco a vinte toneladas por tonelada de pele processada, os quais são, normalmente, dispostos de forma inadequada. Hemphill Jr. et al. (1985) relatam que o alto teor de $\mathrm{N} \mathrm{e} \mathrm{CaCO}_{3}$ contido nestes resíduos indicam que a sua aplicação em solos cultivados pode trazer benefícios à produção agrícola. 
Por outro lado, estes resíduos apresentam elevada concentração de crômio e sódio, cujo acúmulo no solo pode proporcionar impactos negativos sobre o desenvolvimento das culturas e propriedades físicas do solo, que precisam ser melhor avaliados.

Mertz (1969), identificou o crômio como elemento essencial à nutrição humana (responsável pelo fator de tolerância à glicose), sendo as plantas a principal fonte suplementar. Por outro lado, Huffman \& Allaway (1973) foram conclusivos em desconsiderar sua necessidade para um crescimento normal da alface, feijão e tomate.

$\mathrm{Na}$ forma hexavalente, o crômio aparece como um ânion solúvel que penetra facilmente através da membrana celular, possuindo uma ação tóxica aguda por ser um forte agente oxidante. O crômio trivalente, por sua vez, é solúvel somente a valores de $\mathrm{pH}$ menores do que 5,0 ou quando complexado com moléculas orgânicas de baixo peso molecular, que possuem pouca mobilidade através da membrana celular. (Bartlett \& James, 1988).

$\mathrm{O} \mathrm{Cr}(\mathrm{VI})$ é considerado a forma mais tóxica para as plantas (Skelffington et al, 1976; Mcgrath 1982; Mortvedt \& Giordano, 1975). Em estudo realizado em vasos, Bartllet \& James (1979) observaram sintomas severos de toxicidade em alfafa, feijão e mostarda, cultivadas em solo que recebeu $30 \mathrm{mmol} . \mathrm{kg}^{-1}$ de cloreto de crômio $\left(\mathrm{CrCl}_{3}\right)$, sendo a toxicidade atribuída ao teor de Cr(VI) formado no solo $\left(0,26 \mathrm{mmol} . \mathrm{kg}^{-1}\right)$ pela oxidação do $\mathrm{Cr}(\mathrm{III})$ aplicado.

A absorção de $\mathrm{Cr}(\mathrm{III})$ e $\mathrm{Cr}(\mathrm{VI})$ pelas plantas acontece por mecanismos diferenciados. Skeffington et al. (1976), utilizando inibidores metabólicos, reduziu a absorção de $\operatorname{Cr}(\mathrm{VI})$, demonstrando que este processo ocorre de forma ativa. Já a absorção de Cr(III) não foi afetada, indicando que, neste caso, o metal penetra nas raízes por um simples mecanismo de osmose, sendo classificada como uma absorção passiva.

A absorção de crômio pelas plantas está diretamente associada à presença de formas solúveis do elemento no meio em que são cultivadas. Em diversos estudos desenvolvidos em solução nutritiva, não se encontrou diferença significativa entre a 
absorção de Cr(VI) e Cr(III) (Cary et al., 1977a; Huffman \& Allaway, 1973; McGrath, 1982; Ramachandran et al., 1980). Este comportamento, entretanto, pode mudar significativamente no solo onde, além da valência do elemento, diversos outros fatores estarão interagindo, principalmente o $\mathrm{pH}$ do meio e a presença de agentes complexantes.

Entretanto, uma pequena translocação do crômio absorvido pelas raízes para a parte aérea das plantas, tem sido uma constatação comum em diversos estudos realizados. (Lahouti \& Peterson, 1979; Shewry \& Peterson, 1974; Barcelo et al. (1985); Cary et al., 1977; Huffman e Allaway, 1973; Mortvedt \& Giordano, 1975; Ramachandran et al., 1980; e Selbach et al., 1991). Por outro lado, Adrian (1991) adverte que a aplicação de doses elevadas de crômio ao solo, torna ineficiente o mecanismo que regula sua absorção, permitindo que este elemento se transloque por toda a planta.

O crômio está presente nos resíduos de curtume na forma trivalente, em sua maior parte complexado pela matéria orgânica ou precipitado na forma de hidróxido, formas de difícil assimilação pela planta., todavia, Bartlett \& James (1979) reportam que, em solos úmidos, com teores elevados de Mn facilmente redutível, o $\mathrm{Cr}$ (III) pode ser oxidado a $\mathrm{Cr}(\mathrm{VI})$. Uma vez que os constituintes orgânicos do resíduo desempenham importante papel em impedir que à oxidação a forma hexavalente ocorra de maneira significativa, as transformações sofridas por estes constituintes (mineralização), ao aplicar-se o resíduo ao solo, devem ser estudadas, pois podem liberar uma quantidade apreciável do $\mathrm{Cr}$ (III) para ser oxidada, trazendo riscos à qualidade da água subterrânea ou mesmo prejudicando a produção agrícola.

Outro fato relevante é a elevada quantidade de sais inorgânicos utilizada no processo de curtimento, principalmente de sódio e cálcio, o que pode causar a elevação da concentração de sais na solução do solo pela aplicação de altas doses destes resíduos podendo gerar sérios problemas já relatados, mas pouco enfatizados em alguns trabalhos sobre o assunto (Wickliff et al., 1982; Sykes et al., 1981 e Stomberg et al, 1984). 
Os objetivos deste estudo foram os de avaliar os efeitos causados pela aplicação de resíduos de curtume e $\mathrm{CrCl}_{3}$, sobre o desenvolvimento e a concentração de crômio absorvido pela cultura da alface, a dinâmica de evolução do $\operatorname{Cr}(\mathrm{VI})$, durante o período de desenvolvimento da cultura e algumas alterações químicas conseqüentes, em dois latossolos com potenciais diferenciados em oxidar o crômio trivalente.

\section{MATERIAL E MÉTODOS}

Solos - Foram utilizadas amostras dos horizontes A de dois latossolos do Estado de São Paulo, classificados por Oliveira et al. (1979) como latossolo roxo eutrófico, textura argilosa, unidade Ribeirão Preto - LRe, (Typic Eutrorthox), coletado na Estação Experimental de Ribeirão Preto do Instituto Agronômico (SP), e latossolo vermelho-amarelo, álico, textura média, unidade Laranja Azeda - LV-3 (Typic Haplortox), coletado na Fazenda Campininha do Instituto Florestal em Martinho Prado (SP). Detalhes da caracterização destes solos são apresentados em outro trabalho (Aquino Neto et al., 1998), e os resultados encontram-se no quadro 1.

Lodos - Os lodos foram coletados no Curtume Podboi, localizado em Leme, SP. Dois tipos de lodo foram amostrados: (i) lodo produzido no decantador primário ( $\mathbf{L C r}$ ), resultante da reunião de todos os efluentes gerados no processo, inclusive o da etapa de curtimento ao crômio e (ii) lodo produzido pela precipitação do efluente gerado na etapa de caleiro (LCL), realizada em bombonas de plástico por meio do abaixamento do $\mathrm{pH}$ do efluente até 5,5, determinado por meio de JAR-teste. Após a precipitação e separação do lodo, o $\mathrm{pH}$ da mistura foi elevado até 8,0 novamente. Detalhes da caracterização destes lodos são apresentados em outro trabalho (Aquino Neto et al., 1998), e os resultados encontram-se no quadro 2. 
Quadro 1 Características químicas e físicas das amostras de solo estudadas

\begin{tabular}{|c|c|c|c|}
\hline \multirow[b]{2}{*}{ Parâmetro } & \multirow[b]{2}{*}{ Unidade } & \multicolumn{2}{|c|}{ Solos } \\
\hline & & $\begin{array}{c}\text { LV-3 - Laranja } \\
\text { Azeda }\end{array}$ & $\begin{array}{c}\text { LR - Ribeirão } \\
\text { Preto }\end{array}$ \\
\hline Carbono Orgânico Total & g. $\mathrm{kg}^{-1}$ & 11,6 & 14,0 \\
\hline Mn facilmente redutível & $\mathrm{mg} \cdot \mathrm{kg}^{-1}$ & 0,00 & 191,7 \\
\hline Mn total & mg.kg ${ }^{-1}$ & 41,00 & 717,0 \\
\hline Cr total & mg.kg-1 & $<0,30$ & 34,0 \\
\hline $\mathrm{K}$ trocável & $\mathrm{mmol}_{\mathrm{c}} \cdot \mathrm{dm}^{-3}$ & 0,2 & 0,1 \\
\hline Ca trocável & $\mathrm{mmol}_{\mathrm{c}} \cdot \mathrm{dm}^{-3}$ & 4,0 & 1,3 \\
\hline Mg trocável & $\mathrm{mmol}_{\mathrm{c}} \cdot \mathrm{dm}^{-3}$ & 1,0 & 1,3 \\
\hline Na trocável & mg.dm ${ }^{-3}$ & 4,6 & 4,6 \\
\hline CTC & $\mathrm{mmol}_{\mathrm{c}} \cdot \mathrm{dm}^{-3}$ & 5,2 & 8,8 \\
\hline P-resina & $\mu \mathrm{g} . \mathrm{cm}^{-3}$ & 3,0 & 24,0 \\
\hline Argila & g. $\mathrm{kg}^{-1}$ & 120 & 560 \\
\hline Silte & g. $\mathrm{kg}^{-1}$ & 50 & 300 \\
\hline Areia & g. $\mathrm{kg}^{-1}$ & 830 & 140 \\
\hline $\mathrm{Ug} 0,1$ bar & g. $\mathrm{kg}^{-1}$ & 114 & 366 \\
\hline Ug 0,3 bar & g.kg ${ }^{-1}$ & 94 & 335 \\
\hline $\mathrm{pH}-\mathrm{H}_{2} \mathrm{O}(1: 1)$ & & 4,0 & 5,0 \\
\hline
\end{tabular}

Quadro 2. Composição química dos lodos de curtume utilizados

\begin{tabular}{cccc}
\hline Parâmetro & Unidade & \multicolumn{2}{c}{ Lodo } \\
\cline { 3 - 4 } & & $\begin{array}{c}\text { Decantador } \\
\text { primário }\end{array}$ & Caleiro \\
\hline pH & & 8,00 & 8,00 \\
Umidade & $\mathrm{g} \cdot \mathrm{kg}^{-1}$ & 817,20 & 689,00 \\
Carbono Orgânico total & $\mathrm{mg} \cdot \mathrm{kg}^{-1}$ & 239,30 & 240,80 \\
Crômio total & $\mathrm{mg} \cdot \mathrm{kg}^{-1}$ & 17350,00 & 60,00 \\
Nitrogênio total & $\mathrm{mg} \cdot \mathrm{kg}^{-1}$ & 31202,82 & 59346,60 \\
Fósforo total & $\mathrm{mg} \cdot \mathrm{kg}^{-1}$ & 1059,70 & 892,40 \\
Potássio total & $\mathrm{mg} \cdot \mathrm{kg}^{-1}$ & 1660,00 & 1920,00 \\
Sódio total & $\mathrm{mg} \cdot \mathrm{kg}^{-1}$ & 52500,00 & 66000,00 \\
Cálcio total & $\mathrm{mg} \cdot \mathrm{kg}^{-1}$ & 87200,00 & 67000,00 \\
Magnésio total & $\mathrm{mg} \cdot \mathrm{kg}^{-1}$ & 7540,00 & 472,80 \\
Manganês total & $\mathrm{mg} \cdot \mathrm{kg}^{-1}$ & 6350,00 & 966,00 \\
\hline
\end{tabular}


Incubação: o experimento foi conduzido em casa de vegetação, em microparcelas constituídas por vasos com $5 \mathrm{dm}^{3}$ de volume, com sistema de suprimento de água por mecha de tecido. Os vasos foram montados utilizando-se $3,5 \mathrm{dm}^{3}$ de cada solo, considerando-se as seguintes densidades: LVA - $1314 \mathrm{~kg} \cdot \mathrm{m}^{-3}$ e LRe - $1162 \mathrm{~kg} \cdot \mathrm{m}^{-3}$. Para cada um dos solos estudados foram montados os seguintes tratamentos:

1) testemunha: que recebeu apenas adubação mineral : $400 \mathrm{mg}$ de $\mathrm{N}\left[\mathrm{Ca}\left(\mathrm{NO}_{3}\right)\right.$ e $\left.\mathrm{Mg}\left(\mathrm{NO}_{3}\right)\right], 77 \mathrm{mg}$ de $\mathrm{P}$ (Supertriplo), $660 \mathrm{mg}$ de $\mathrm{K}(\mathrm{KCl}), 165 \mathrm{mg}$ de $\mathrm{Ca}$ $\left(\mathrm{CaSO}_{4} \cdot 2 \mathrm{H}_{2} \mathrm{O}\right), 44 \mathrm{mg}$ de $\mathrm{Mg}\left(\mathrm{MgCl}_{2}\right)$ e $0,4 \mathrm{mg}$ de $\mathrm{B}$, conforme extração de nutrientes verificada por Furlani et al. (1985) para produção de $11 \mathrm{~g}$ de matéria seca.

2) crômio trivalente: que recebeu a mesma adubação mineral do tratamento testemunha e $\mathrm{CrCl}_{3} \cdot 6 \mathrm{H}_{2} 0$, proporcionando as seguintes doses de crômio : 122, 244 e $366 \mathrm{mg} \cdot \mathrm{kg}^{-1}$ para o LVA e 148, 296 e 444 mg.kg ${ }^{-1}$ para o LRe.

3) lodo de caleiro (LCL): nas doses de 10, 20 e 30 ton.ha $^{-1}$ em base seca, proporcionando uma aplicação de 226, 452 e $678 \mathrm{mg} \cdot \mathrm{kg}^{-1}$ de N para o LVA e 256, 512 e $768 \mathrm{mg} \cdot \mathrm{kg}^{-1}$ de $\mathrm{N}$ para o LRe, acrescidos da mesma adubação mineral realizada para o tratamento testemunha, menos o nitrogênio e o cálcio.

4) lodo do decantador primário (LCR): nas doses de 19, 38 e $57 \mathrm{Mg} . h a^{-1}$ em base seca, proporcionando as mesmas aplicações de $\mathrm{N}$ do tratamento 3 e de crômio do tratamento 2, acrescidos da mesma adubação mineral realizada para o tratamento testemunha, menos o nitrogênio e o cálcio.

As doses de lodo e cromo de cada tratamento foram adotadas de acordo com a necessidade de $\mathrm{N}$ da cultura( $(0,5,1$ e 2 vezes $)$.

A correção da acidez $\left(\mathrm{CaCO}_{3}+\mathrm{MgO} 3: 1\right)$, foi realizada seguindo curva de neutralização, elaborada pela incubação dos solos com o sal de crômio e com o resíduo (dados não apresentados), de maneira a atingir pH em água igual a 6,5.

Cinco gramas de solo úmido de cada vaso foram amostrados após 1,6 , $14,28,54$ e 86 dias de incubação, para determinação do crômio hexavalente, extraído 
com $25 \mathrm{~mL}$ de água deionizada e $0,2 \mathrm{~mL}$ de fosfato de potássio $\left(1 \mathrm{~mol} . \mathrm{L}^{-1}\right.$ $\mathrm{KH}_{2} \mathrm{PO}_{4} \cdot \mathrm{K}_{2} \mathrm{HPO}_{4}$ ), após agitação por 30 min e quantificado colorimetricamente por difenilcarbazida a $540 \mathrm{~nm}$, no extrato conseguido após centrifugação $(35.000 \mathrm{~g}$ por10 minutos) e filtração (millipore 0,45 $\mu$ ), conforme descrito por Bartlett e James (1979). Outras $10 \mathrm{~g}$ de solo foram amostradas para determinação do teor de umidade a $105^{\circ} \mathrm{C}$ por $24 \mathrm{~h}$.

Após o $56^{\circ}$ dias de incubação, foi plantada uma muda de alface por vaso. As mudas foram produzidas por hidroponia e apresentavam-se homogêneas e no momento do transplante estavam com trinta dias de idade. As plantas de alface foram colhidas um mês após o plantio, lavadas com água destilada, secas a $70{ }^{\circ} \mathrm{C}$ determinando-se o seu peso seco e moendo-as em seguida. A concentração de crômio total, na parte aérea das plantas de alface, foi determinada em ICP-AES, após digestão via úmida em forno de microondas, conforme descrito por Abreu (1997).

O delineamento experimental foi de blocos ao acaso, totalizando vinte tratamentos com três repetições. Foi utilizado o método dos contrastes ortogonais na análise estatística com o objetivo de isolar os efeitos mais significativos no desenvolvimento da alface. Os seguintes contrastes foram realizados: 1) LVA x LRe e

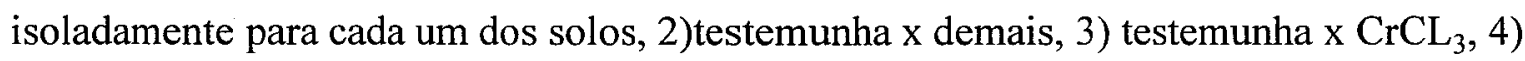
$\mathrm{CrCl}_{3} \times$ LCR e 5) LCR x LCL. Para os outros parâmetros fez a comparação das médias, utilizando-se o teste de Tukey.

As amostras de solo, ao final do experimento, foram secas ao ar e passadas em peneira com malha de $2 \mathrm{~mm}$. O extrato de saturação (2:1), obtido conforme descrito por Camargo et al. (1986), foi analisado para a condutividade elétrica (CE), concentração de carbono orgânico total (TOC analyser), sódio, cálcio e magnésio (absorção atômica) e crômio solúvel em água conforme descrito por Kozuh et al. (1994). 


\section{RESULTADOS E DISCUSSÃO}

Evolução do Cr(VI): Não foi detectada a presença de $\mathrm{Cr}(\mathrm{VI})$ no latossolo vermelho-amarelo em nenhum dos tratamentos realizados ao longo de todo o período de incubação. Quanto ao latossolo roxo, foi verificada a formação de $\operatorname{Cr}(\mathrm{VI})$ somente no tratamento com adição de crômio na forma de $\mathrm{CrCl}_{3}$. A figura 1 apresenta a evolução dos teores de crômio hexavalente encontrados para este tratamento. Convém ressaltar que, no trigésimo dia de incubação, os vasos foram remontados, com a intenção de se uniformizar as microparcelas após a retirada de amostras e realizar o plantio de mudas de alface. Este procedimento, entretanto, não deve ter alterado a tendência já verificada de decréscimo do $\mathrm{Cr}(\mathrm{VI})$ nos tratamentos, como pode ser identificado pelo teor no $28^{\circ}$ dia de incubação.

Diversos trabalhos demonstraram que a oxidação do $\operatorname{Cr}(\mathrm{III})$ à forma hexavalente ocorre em solos com teores elevados de óxidos de manganês facilmente redutíveis (Bartlett \& James, 1979; Eary \& Rai ,1987; Johnson \& Xyla, 1991, Fendorf \& Zasoski, 1992 e Trebien, 1994), o que justifica a tendência das curvas da figura 1 e explica também o comportamento do elemento para os dois solos. Ressalta-se que os óxidos de manganês facilmente redutíveis não foram detectados no latossolo vermelhoamarelo, enquanto que o latossolo roxo possuía um teor de 191,71 mg. $\mathrm{kg}^{-1}$ na montagem do experimento (Quadro 1).

A formação de $\mathrm{Cr}(\mathrm{VI})$ no latossolo roxo, nos tratamentos que receberam $\mathrm{CrCl}_{3}$, foi muito rápida, alcançando valores máximos um dia após a incubação. Os teores do $\operatorname{Cr}(\mathrm{VI})$ formado foram diretamente proporcionais aos valores aplicados (Figura 1). Em média, 0,72 a $1,16 \%$ do $\mathrm{Cr}(\mathrm{III})$ aplicado oxidou-se à forma $\mathrm{Cr}(\mathrm{VI})$. Este resultado é praticamente igual ao observado por James \& Bartlett (1984) que, ao aplicarem 10 milimols de $\mathrm{Cr}(\mathrm{OH})_{3}$ por quilograma de solo, notaram que $1,12 \%$ do $\mathrm{Cr}(\mathrm{III})$ sofreu oxidação um dia após a sua aplicação. 
O decréscimo na formação de $\mathrm{Cr}(\mathrm{VI})$ foi abrupto, embora não tenha sido na mesma intensidade da sua formação inicial (Figura 1). A observação da inclinação das curvas de $\mathrm{Cr}(\mathrm{VI})$ permite concluir que este decréscimo foi maior para o tratamento no qualonde foi aplicada a dose menor de $\mathrm{Cr}(\mathrm{III})$. Neste, as concentrações já estavam relativamente baixas após o sexto dia, não sendo mais detectada a presença de crômio hexavalente após 28 dias de incubação. Conforme observou Trebien (1994), o decréscimo na formação de $\mathrm{Cr}(\mathrm{VI})$ pode ser atribuído a uma progressiva diminuição da concentração de $\mathrm{Cr}(\mathrm{III})$, em virtude da sua precipitação a formas menos solúveis, que ocorre paralelamente ao processo de oxidação. Bartlett e Kimble (1976a), observaram uma completa precipitação do crômio trivalente a partir de um pH do solo acima de 4,5. O latossolo roxo, ao final do experimento, apresentou um $\mathrm{pH}$ 7,0 em média, para os tratamentos onde foi aplicado o $\mathrm{CrCl}_{3}$. Fendorf et al. (1992), observaram que a precipitação do crômio na forma de $\mathrm{Cr}(\mathrm{OH})_{3} \cdot \mathrm{nH}_{2} \mathrm{O}$ é o principal mecanismo inibidor da oxidação do Cr(III), por ser um precipitado reduzido muito estável e por formar uma barreira entre o metal em solução e os óxidos de Mn. Nos valores de pH encontrado, a adsorção do crômio a outros minerais, que não os óxidos de Mn pode também ter influenciado a rápida diminuição da taxa de oxidação. Dubbin \& Goh (1995) observaram que o $\mathrm{Cr}$ (III) forma um complexo de esfera interna de superfície com o grupo siloxana dos minerais de argila, ficando fortemente ligado e tornando muito difícil a sua liberação por reações de troca mais simples.

Por ser o $\mathrm{Cr}(\mathrm{VI})$ um agente oxidante muito forte, a presença de doadores de elétrons no solo proporciona sua redução à forma trivalente. No solo os doadores de eletrons mais comuns são a matéria orgânica (Bartlett \& Kimble, 1976b; James \& Bartlett, 1983bc; Losi et al. 1994; Wittbrodt \& Palmer,1995)e o Fe(II) em solução ou os minerais de ferro (Eary \& Rai, 1991; Fendorf \& Li, 1996; Eary \& Rai, 1988). Este processo ocorre paralelamente ao de oxidação e, a partir do momento em que sua velocidade de reação é superior à de formação do crômio hexavalente, a concentração deste último diminuirá progressivamente. 
O crômio trivalente aplicado na forma de lodo não sofreu oxidação à forma hexavalente em razão de estar presente, neste resíduo, em formas insolúveis ou complexadas com as proteínas do tecido cutâneo. Outra provável razão é o decréscimo dos teores de óxido de manganês facilmente redutíveis, graças a reações em que este oxida a matéria orgânica, conforme observado por Trebien (1994), que concluiu existir uma relação inversa entre a velocidade de reação de oxidação do $\mathrm{Cr}$ (III) e o teor de matéria orgânica do solo ou a adição de compostos orgânicos.

A formação de $\mathrm{Cr}(\mathrm{VI})$ no solo, após a aplicação de resíduo de curtume, foi verificada por James \& Bartlett (1983b), mesmo ante a presença de altos níveis de redutores orgânicos presentes nestes resíduos. Segundo Bartlett \& James (1988), a formação de $\mathrm{Cr}(\mathrm{VI})$, pela aplicação destes resíduos ao solo, pode ocorrer em condições ótimas de oxidação, entretanto, em virtude da natureza dos constituintes presentes, esta formação ocorrerá de forma lenta e em pequenas quantidades.

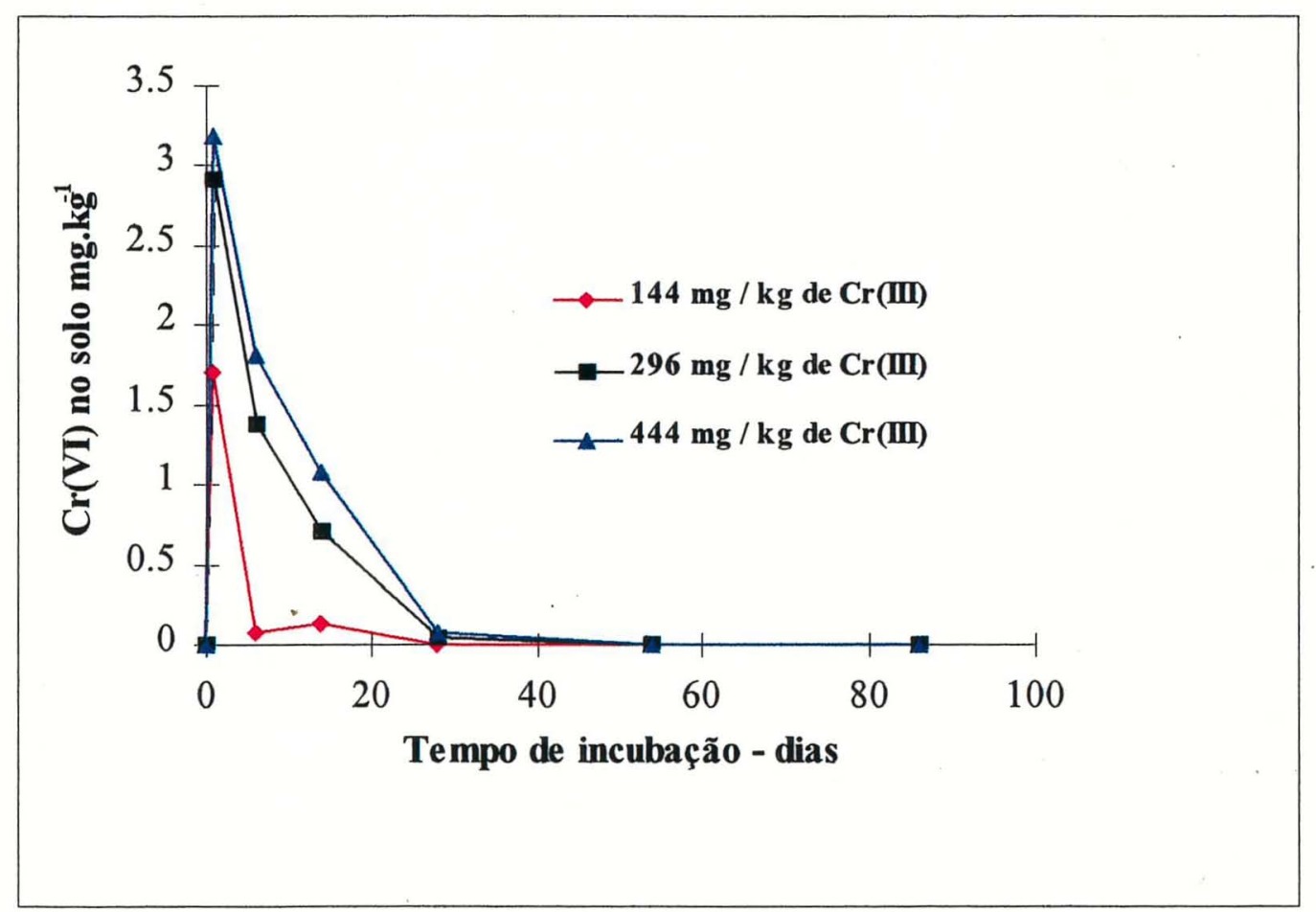

Figura 1 Evolução do Cr(VI) em latossolo roxo, unidade Ribeirão Preto em função do tempo de incubação e da adição de $\mathrm{CrCl}_{3}$ (média de três repetições). 
Crescimento da alface: o quadro 3 apresenta os rendimentos médios acumulados em matéria seca da parte aérea da alface e a concentração de Cr total na parte aérea das plantas. Observou-se uma grande variação na produção de matéria seca entre os tratamentos realizados (0,59 a 13,2 gramas), evidenciando que as plantas de alface foram muito afetadas ao longo do período de crescimento, pelos tratamentos que receberam doses progressivas dos dois lodos estudados (LCL e LCR). Logo após o plantio das mudas $\left(1^{\circ}\right.$ e $2^{\circ}$ dias), já era possível notar que as plantas dos tratamentos onde os lodos foram aplicados não apresentavam sinais de recuperação do stress do transplante, permanecendo as folhas mais velhas murchas e, em alguns casos (taxas mais elevadas), já totalmente secas, e as folhas mais novas com coloração verde muito intensa. Esta tendência foi mantida ao longo de todo o tratamento. A maioria das plantas cultivadas nos solos que receberam as doses maiores de lodo morreram e foram colhidas à partir da segunda semana de plantio. $\mathrm{O}$ impacto da aplicação dos lodos foi muito maior para o LVA, no qual somente a dose mais baixa dos lodos não causou a morte das plantas. Todavia, mesmo nestes tratamentos, a inibição do crescimento da alface foi severa. No LRe, a inibição do crescimento foi menos acentuada e apenas a maior dose de LCR (57 Mg.ha ${ }^{-1}$ ) causou a morte das plantas, entretanto, o crescimento da cultura foi severamente afetado pelas aplicações de LCL nas doses de 20 e $30 \mathrm{Mg}^{-h^{-1}} \mathrm{e} \mathrm{LCR} \mathrm{na}^{-1}$ dose de $38 \mathrm{Mg} \cdot \mathrm{ha}^{-1}$.

A análise da variância demonstrou existir diferença significativa entre a produtividade da alface nos dois solos estudados, sendo esta maior no LRe do que no LVA. O segundo contraste analisado demonstrou que, em média, o tratamento testemunha superou os demais nos dois solos, entretanto, foi encontrada diferença significativa apenas no LVA quando se comparou o controle com os tratamentos onde o crômio foi aplicado na forma de sal $\left(\mathrm{CrCl}_{3}\right)$. Este último tratamento superou os tratamentos onde o crômio foi aplicado por meio do lodo (LCR), que por sua vez, não apresentou diferença significativa quando comparado com os tratamentos que receberam o lodo sem crômio (LCL), em ambos os solos. 
A análise dos contrastes demonstrou que a aplicação de doses crescentes de crômio na forma de sal, afetou o desenvolvimento da alface somente no LVA. Este comportamento não era esperado, uma vez que a forma hexavalente do metal, considerada a mais tóxica para as plantas (Skelffington et al., 1976; Bartlett \& James, 1988) foi detectada somente no LRe e por curto período de tempo. Ao longo do período de cultivo, em nenhum dos solos se observou a formação de $\mathrm{Cr}(\mathrm{VI})$. O $\mathrm{Cr}(\mathrm{III})$ por sua vez, apenas apresenta efeitos tóxicos para as plantas em meios muito ácidos, pois a sua biodisponibilidade é muito reduzida a $\mathrm{pH}>5,0$ (Mcgrath \& Smith, 1990), quando se encontra precipitado no solo (Bartlett e Kimble, 1976a). Nas condições do estudo os dois solos apresentavam-se com o pH acima de 6,5. Entretanto, foi detectada a presença de $\mathrm{Cr}$ em solução (Quadro 4) apenas para o LVA e somente nestes tratamentos, o que pode justificar os efeitos observados. Apesar dos valores de $\mathrm{pH}$ observados, a presença de $\mathrm{Cr}$ em solução nestes tratamentos pode ser explicado pela concentração de COD observada no LVA, que foi três vezes superior a verificada para o LRe. (Quadro 4). James \& Bartlett (1983a) demonstraram que o $\mathrm{Cr}$ (III) forma complexos com compostos orgânicos presentes na solução do solo que permaneceram solúveis em $\mathrm{pH}$ superiores a 7,0. Estes autores, observaram ainda uma diminuição no peso seco de milho e feijão cultivados em solos tratados com $\mathrm{Cr}(\mathrm{OH})_{3}$ que foi acentuada nos tratamentos que receberam ácido cítrico, atribuídos ao aumento do $\mathrm{Cr}(\mathrm{III})$ em solução e à maior quantidade de $\mathrm{Cr}(\mathrm{VI})$ formada. Wallace et al. (1976), observaram que a aplicação de EDTA ao solo aumentou a toxicidade do crômio trivalente à cultura do feijão.

$\mathrm{O}$ fato de os tratamentos que receberam $\mathrm{CrCl}_{3}$ apresentarem uma produção de matéria seca superior aos tratamentos onde foi aplicado o lodo com crômio (LCR) e estes não se diferenciarem daqueles tratamentos que receberam lodo sem crômio (LCL), permite concluir que, o crômio contido no resíduo não apresentou comportamento fitotóxico para a alface cultivada, ou que este efeito foi muito pouco pronunciado para ser detectado, devido ao alto impacto sobre o desenvolvimento das plantas causado pelo aumento da salinidade do solo verificada nos tratamentos que 
receberam os dois tipos de lodos. Esta conclusão encontra embasamento no trabalho realizado por Wickliff et al. (1982) que, ao aplicarem lodos de curtume ao solo, observaram decréscimo na produção de matéria seca de "erva carneira" tratada com $1300 \mathrm{~kg} \cdot \mathrm{ha}^{-1}$ de crômio. Entretanto, segundo eles, a elevada concentração de sais no solo, causada por esta aplicação, não permitiu que este decréscimo fosse atribuído à concentração do metal no solo. Observação semelhante foi realizada por Sykes et al.(1981) e Stomberg et al. (1984), que verificaram efeitos sobre a germinação e desenvolvimento do milho em solos que receberam doses elevadas de lodo de curtume (56 $\mathrm{Mg} \cdot \mathrm{ha}^{-1}$ ), o que resultou em uma condutividade elétrica do extrato de saturação média de $4,3 \mathrm{dS} \cdot \mathrm{m}^{-1}$.

Nos tratamentos que receberam os lodos, a condutividade elétrica do extrato de saturação (2:1) elevou-se com as doses aplicadas, atingindo um máximo de 4,05 (LCL) e 4,14 (LCR) para o LVA e 4,42 (LCL) e 5,07 dS.m ${ }^{-1}$ (LCR) para o LRe, teores suficientemente altos para causar efeitos adversos ao desenvolvimento da alface. Segundo Bohn et al. (1985), a partir de um valor de CE de 2 dS.m ${ }^{-1}$ e 5 dS.m ${ }^{-1}$ espera-se uma diminuição de $10 \%$ e $50 \%$ respectivamente, na produtividade da alface a valores de $5 \mathrm{dS} \cdot \mathrm{m}^{-1}$. Maas (1990), apresenta dados de tolerância à salinidade para diversas culturas, nos quais o valor da CE tolerada pela alface é de $1,3 \mathrm{dS} . \mathrm{m}^{-1}$ e que o acréscimo de uma unidade, diminui em 13\% a produtividade da cultura. Papadopoulos (1987) observou um decréscimo de até $76 \%$ na produção de matéria seca da alface, quando a CE atingiu um valor de $7,3 \mathrm{dS} . \mathrm{m}^{-1}$ no solo. A morte das plantas sujeitas às doses mais elevadas de lodo pode ser entendida quando se leva em conta o fato de os valores obtidos terem sido medidos em extrato de saturação $2: 1$, mais diluído do que o extrato da pasta de saturação (Allison et al., 1969), utilizado na determinação dos valores citados.

Outra evidência de como a concentração de sais influenciou na produtividade da cultura, foram os sintomas nas plantas afetadas, que apresentavam coloração verde escura muito acentuada e paralisação do crescimento. Segundo Bohn et al (1985), as plantas ao se desenvolverem em meios salinos, por meio de um processo 
denominado ajustamento osmótico, aumentam sua concentração osmótica interna pela absorção de sais e produção de ácidos orgânicos, desviando energia de crescimento na tentativa de manter o diferencial osmótico. Como conseqüência as células das folhas continuam a aumentar em número, entretanto, não ocorre a sua elongação, aumentando o número de células por área resultando numa intensificação de coloração.

No LRe, as doses mais baixas dos lodos não afetaram o desenvolvimento da alface. Para o LCR nem para a dose intermediária se notou diferença muito acentuada, provavelmente devido ao maior poder tampão e capacidade de retenção de umidade apresentado por este solo. Com o solo LVA mesmo para os tratamentos que receberam as doses mais baixas do lodo, foi verificado um decréscimo acentuado na produtividade das plantas, ainda que a CE $\left(1,73 \mathrm{dS} . \mathrm{m}^{-1}\right)$ fosse igual ou menor do que os valores observados nos tratamentos onde foi aplicado o $\mathrm{CrCl}_{3}$, os quais apresentaram uma produtividade maior. A elevação do valor da RAS pode ter causado este decréscimo na produtividade, corroborando estudo realizado por Coale et al. (1984), no qual se observou que a produção de matéria seca da soja decresceu com o aumento do valor da RAS em solos com CE baixa $\left(<\cong 2 \mathrm{dS} \cdot \mathrm{m}^{-1}\right)$.

Acúmulo de crômio na alface: A concentração de crômio nas folhas de alface, apresentada no Quadro 3, apresentou uma tendência a elevar-se proporcionalmente com as doses de aplicação deste elemento e de maneira inversa à produção de matéria seca. Este comportamento foi verificado para o LRe e em maior escala para o LVA.

A concentração de crômio nas folhas das plantas cultivadas no LVA variou de $0,23 \mathrm{mg} \cdot \mathrm{kg}^{-1}$ no tratamento testemunha a $8,81 \mathrm{mg} \cdot \mathrm{kg}^{-1}$ no tratamento que

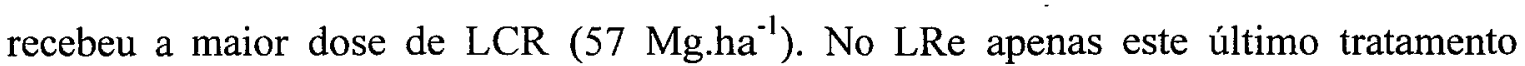
apresentou um acréscimo na concentração do metal $\left(2,63 \mathrm{mg} \cdot \mathrm{kg}^{-1}\right)$, que a exemplo dos demais tratamentos foi quase sempre menor quando comparada ao LVA.

Ainda que o acúmulo de crômio nas raízes devido à pouca translocação para a parte aérea seja um consenso entre a maioria dos trabalhos consultados, como o 
realizado por Shewry \& Peterson (1974), os quais encontraram que apenas $1 \%$ do crômio absorvido translocando para a parte aérea, as concentrações observadas não são consideradas anormais nem excessivamente altas. Smilde (1981) ao aplicar no solo lodo de esgoto enriquecido com metais, encontrou uma concentração de crômio nas folhas de alface variando entre 6,7 e $13,4 \mathrm{mg} \cdot \mathrm{kg}^{-1}$, entretanto a concentração no tratamento controle (3,0 mg. $\left.\mathrm{kg}^{-1}\right)$ estava bem acima da observada neste trabalho. Wickliff et al (1982) observaram que lodo de curtume aplicado ao solo além de diminuir drasticamente a produtividade das plantas, elevou a concentração do metal na parte aérea a um valor três vezes superior ao tratamento controle.

Os dados do Quadro 3 mostram que a concentração de $\mathrm{Cr}$ na alface cultivada no LRe foi muito menor do que no LVA. Estes resultados corroboram os de Figliolia et al. (1992), que além de constatar uma elevação na concentração de crômio nas folhas da alface cultivada em solos que receberam lodo de curtume, observaram que as plantas cultivadas nos solos com textura arenosa apresentavam uma concentração $\left(11,1 \mathrm{mg} \cdot \mathrm{kg}^{-1}\right)$ 2,5 vezes maior do que a verificada para os solos de textura média $\left(4,4 \mathrm{mg} \cdot \mathrm{kg}^{-1}\right)$.

As diferenças observadas na concentração de crômio nas plantas entre os dois solos estudados e entre os diferentes tratamentos, está associada a diversos fatores, alguns já comentados anteriormente, como a presença de teores mais elevados de COD no LVA e a tendência da planta de absorver uma quantidade maior de sais ao crescer em meio com elevada salinidade.

Outro aspecto importante vem a ser a correlação inversa observada entre o a massa seca e a concentração do metal nas plantas. Sykes et al.(1981), encontraram uma correlação não linear (hiperbólica) inversamente proporcional entre a concentração de crômio e a produção de matéria seca. Segundo os autores, as regiões de crescimento das plantas acumulam ions que serão redistribuídos com o seu crescimento, que uma vez inibido, causará uma concentração maior, neste caso, do crômio. 
Quadro 3 Produção de matéria seca e concentração de crômio (média de três repetições), na parte aérea da alface cultivada em dois latossolos tratados com lodos de curtumes e $\mathrm{CrCl}_{3}$.

\begin{tabular}{|c|c|c|c|c|c|}
\hline Tratamento & $\begin{array}{c}\text { Lodo } \\
\text { aplicado }\end{array}$ & $\begin{array}{c}\mathrm{Cr} \\
\text { aplicado }\end{array}$ & $\begin{array}{c}\mathbf{N} \\
\text { aplicado }\end{array}$ & $\begin{array}{c}\text { Matéria } \\
\text { seca }\end{array}$ & $\begin{array}{l}\text { Cr - total } \\
\text { na planta }\end{array}$ \\
\hline & Mg.ha' ${ }^{-T}$ & mg.kg-1 & mg.planta ${ }^{-1}$ & g.planta ${ }^{-1}$ & mg.kg- \\
\hline & \multicolumn{5}{|c|}{ Latossolo vermelho amarelo - Laranja azeda } \\
\hline Testemunha & 0 & 0 & 217 & 7,44 & 0,23 \\
\hline \multirow{3}{*}{$\mathrm{CrCl}_{3}$} & 0 . & 122 & 217 & 4,85 & 3,27 \\
\hline & 0 & 244 & 217 & 4,30 & 2,88 \\
\hline & 0 & 366 & 2.17 & 4,87 & 1,84 \\
\hline \multirow{3}{*}{ LCL } & 10 & 0 & 226 & 2,64 & 1,22 \\
\hline & 20 & 0 & 452 & 0,67 & 1,08 \\
\hline & 30 & 0 & 678 & 0,70 & 0,56 \\
\hline \multirow{3}{*}{ LCR } & 19 & 122 & 226 & 1,62 & 5,70 \\
\hline & 38 & 244 & 452 & 0,71 & 8,63 \\
\hline & 57 & 366 & 678 & 0,88 & 8,81 \\
\hline & \multicolumn{5}{|c|}{ Latossolo roxo - Ribeirão Preto } \\
\hline Testemunha & 0 & & 246 & 13,18 & 0,05 \\
\hline \multirow{3}{*}{$\mathrm{CrCl}_{3}$} & 0 & 148 & 246 & 12,07 & 0,09 \\
\hline & 0 & 296 & 246 & 10,17 & 0,21 \\
\hline & 0 & 444 & 246 & 12,14 & 0,84 \\
\hline \multirow{3}{*}{ LCL } & 10 & 0 & 256 & 12,41 & 0,23 \\
\hline & 20 & 0 & 512 & 4,76 & 0,04 \\
\hline & 30 & 0 & 768 & 1,45 & 0,12 \\
\hline \multirow{3}{*}{ LCR } & 19 & 148 & 256 & 10,85 & 0,01 \\
\hline & 38 & 296 & 512 & 8,37 & 0,03 \\
\hline & 57 & 444 & 768 & 0,59 & 2,63 \\
\hline DMS(Tukey 5\%) & - & - & - & 5,26 & 6,74 \\
\hline $\mathrm{CV}$ & - & - & - & 83,15 & 151,90 \\
\hline
\end{tabular}


Quadro 4 Valores médios de carbono orgânico dissolvido (COD), Cr-solúvel, Condutividade elétrica (CE) no extrato de saturação 2:1 e Razão de adsorção de sódio (RAS) (média de três repetições), após a colheita da alface, para dois latossolos tratados com lodos de curtumes e $\mathrm{CrCl}_{3}$.

\begin{tabular}{|c|c|c|c|c|}
\hline Tratamento & COD & Cr - solúvel & CE (2:1) & RAS \\
\hline & mg.kg-1 & mg.kg-1 & dS.m $\mathbf{m}^{-1}$ & \\
\hline & \multicolumn{4}{|c|}{ Latossolo vermelho amarelo - Laranja azeda } \\
\hline Testemunha & 85,96 & $<0,2$ & 1,07 & 0,03 \\
\hline \multirow{3}{*}{$\mathrm{CrCl}_{3}$} & 147,48 & 0,6 & 1,37 & 0,03 \\
\hline & 151,7 & 0,5 & 1,89 & 0,02 \\
\hline & 146,78 & 0,5 & 2,14 & 0,02 \\
\hline \multirow{3}{*}{ LCL } & 166,96 & $<0,2$ & 1,73 & 3,05 \\
\hline & 309,54 & $<0,2$ & 3,27 & 6,26 \\
\hline & 313,14 & $<0,2$ & 4,05 & 6,14 \\
\hline \multirow{3}{*}{ LCR } & 211,98 & $<0,2$ & 1,71 & 6,56 \\
\hline & 256,14 & $<0,2$ & 2,82 & 10,24 \\
\hline & 302,40 & $<0,2$ & 4,14 & 14,12 \\
\hline & \multicolumn{4}{|c|}{ Latossolo Roxo - Ribeirão Preto } \\
\hline Testemunha & 38,34 & $<0,2$ & 0,90 & 0,03 \\
\hline \multirow{3}{*}{$\mathrm{CrCl}_{3}$} & 47,88 & $<0,2$ & 1,55 & 0,02 \\
\hline & 47,88 & $<0,2$ & 2,02 & 0,02 \\
\hline & 42,08 & $<0,2$ & 2,33 & 0,02 \\
\hline \multirow{3}{*}{ LCL } & 47,30 & $<0,2$ & 1,40 & 3,36 \\
\hline & 67,12 & $<0,2$ & 3,34 & 6,68 \\
\hline & 113,02 & $<0,2$ & 4,42 & 8,78 \\
\hline \multirow{3}{*}{ LCR } & 41,36 & $<0,2$ & 1,52 & 6,18 \\
\hline & 63,16 & $<0,2$ & 2,86 & 7,66 \\
\hline & 116,90 & $<0,2$ & 5,07 & 12,70 \\
\hline DMS (Tukey 5\%) & 80.61 & 0,21 & 0.58 & 3.99 \\
\hline CV & 70,66 & 48,75 & 47,96 & 100,13 \\
\hline
\end{tabular}


Concentração de sódio : o sódio trocável no solo é apresentado no quadro 4 pela razão de adsorção de sódio (RAS). O RAS do solo aumentou proporcionalmente com as doses dos dois lodos aplicados. seguindo a mesma tendência da CE, entretanto, foi sempre maior para o LCR, comportamento esperado, uma vez que, ainda que o balanço de sais presentes no resíduo fossem semelhantes devido às diferentes concentrações de N-total, o LCR foi aplicado a taxas quase duas vezes superiores ao LCL. Os valores observados para este índice são considerados altos, variando de 3,05 a 8,75 para o LCL e de 6,18 a 14,12 para o LCR. Solos sódicos possuem um RAS superior a 15 (Bohn et al., 1985). Nesta situação, os solos começam a apresentar decréscimo na permeabilidade, diminuindo a infiltração de água, acentuando o problema de concentração de sais, diminuindo a disponibilidade de água para as plantas, aumentando o risco de erosão e, em casos mais graves, diminuindo a disponibilidade de outros cátions, que são lixiviados ou mesmo resultando em toxicidade para as plantas mais sensíveis à presença do sódio.

\section{CONCLUSÕES}

1. A reação de oxidação do $\mathrm{Cr}(\mathrm{III})$, observada para o latossolo roxo no tratamento que recebeu crômio na forma de sal inorgânico, foi muito rápida nas condições do experimento e proporcional ao montante de $\mathrm{Cr}$ aplicado.

2. O crômio presente no lodo de curtume (LCR), não sofreu oxidação e aparentemente encontra-se em formas complexadas que se disponibilizam muito lentamente, não causando efeitos adversos ao solo e à produtividade da alface.

3. O maior impacto resultante da aplicação dos resíduos ao solo nas condições do presente estudo foi a elevação acentuada da condutividade elétrica e da RAS a valores considerados prejudiciais para a atividade agrícola. 


\section{CONCLUSÕES GERAIS}

Os resultados obtidos no presente trabalho permitiram as seguintes conclusões:

1. A reação de oxidação do $\mathrm{Cr}(\mathrm{III})$, observada para o latossolo roxo no tratamento que recebeu crômio na forma de sal inorgânico, foi muito rápida nas condições do experimento e proporcional ao montante de $\mathrm{Cr}$ aplicado. Embora a formação de $\mathrm{Cr}(\mathrm{VI})$ tenha sido pequena, em determinadas condições ambientais, esta poderia causar a contaminação de aquíferos.

2. O crômio presente no lodo de curtume (LCR), não sofreu oxidação e aparentemente encontra-se em formas complexadas que se disponibilizam muito lentamente, não causando efeitos adversos ao solo e à produtividade da alface, entretanto, a sua acumulação indiscriminada no solo não é desejável, uma vez que mudanças nas práticas de manejo podem alterar significativamente o comportamento deste elemento. Estudos com períodos de observação mais prolongados são recomendáveis nesta situação.

3. O maior impacto resultante da aplicação dos resíduos ao solo nas condições do presente estudo foi a elevação acentuada da condutividade elétrica e da RAS a valores considerados prejudiciais para a atividade agrícola. Estas observações podem limitar a utlização dos lodos para esta finalidade, a qual deve ser melhor estudada em 
diferentes condições de campo, devendo-se dar especial atenção ao período do ano em que a evapotranspiração supera as precipitações.

4. As diferenças verificadas na mineralização entre os dois lodos de curtume estudados, lodo do caleiro (LCL) e lodo do decantador primário (LCR), permitiu concluir que a presença de elevados teores de crômio no LCR, diminuíram a velocidade de mineralização do N-orgânico de maneira acentuada. Este fato limita o aproveitamento agrícola deste último à correção da acidez do solo, portanto, subaproveitando seu potencial, evidenciado pela comparação com os resultados obtidos com o LCL, isento do metal. A conjunção das exigências ambientais às necessidades agrícolas das culturas, indicam que o procedimento lógico a ser adotado seria a segregação das fontes de crômio dentro do processo de tratamento dos efluentes, gerando um lodo mais apropriado à reciclagem de nutrientes para as culturas.

5. O modelo proposto por Standford \& Smith (1972) para a mineralização de N se ajustou adequadamente aos dados experimentais obtidos para o lodo do caleiro (LCL), mas não aos dados do lodo do decantador primário (LCR), indicando que a mineralização do $\mathrm{N}$-orgânico neste caso não segue uma equação cinética de primeira ordem, ou requer um modelo mais complexo, que leve em conta as diferentes frações recalcitrantes presentes no lodo. 


\section{REFERÊNCIAS BIBLIOGRÁFICAS}

ABREU, M.F. de. Extração e determinação simultânea por emissão em plasma de nutrientes e elementos tóxicos em amostras de interesse agronômico. Campinas, 1997. 132p. Tese (Doutorado) - Unicamp.

ADRIAN, J. Incidence de l'épandage des boues urbaines sur l'apport de chrome alimentaire. Bull. Acad. Natle. Méd., v.175, n.6, p.849-859, juin 1991.

ADRIANO, D.C. Chromium. In: Trace elements in the terrestrial environment. New York: Springer-Verlag., cap.5, p156-180, 1986.

ALLISON, L.E. et al. Determination of the properties of saline and alkali soils. In: RICHARDS, L.A. (Ed.) Diagnosis and improvement of saline and alkali soils. Washington:United States Department of Agriculture, Agriculture Handbook No.60, 1969. cap.2, p.7-33. 
ALLAWAY, W.H. Agronomic controls over the environmental cycling of trace elements. Advances in Agronomy, New York, v.20, p.235-274.

ALLOWAY, B.J. Soil Processes and the behaviour of metals. In: ALLOWAY, B.J. (Ed.) Heavy metals in soils. New York: John Wiley \& Sons, Inc., 1990. cap 2, p.728.

ANDERSON, L.D.; KENT, D.B.; DAVIS, J.A. Batch experiments characterizing the reduction of $\mathrm{Cr}(\mathrm{VI})$ using suboxic material from a mildly reducing sand gravel aquifer. Environmental Science and Technology, v.28, p.178-185, 1994.

ANGLIAN WATER SERVICE. Manual of good practice for utilization of sewage sludge in agriculture. Inglaterra: AW, 1991. 53p.

AQUiNO NETO, V., CAMARgO, O.A., CANTARELlA, H. Potencial de mineralização do nitrogênio em lodos de curtume adicionados a dois latossolos. Revista Brasileira de Ciência do Solo, submetido a publicação, 1998.

ASSOCIAÇÃO BRASILEIRA DE QUÍMICOS E TÉCNICOS DA INDÚSTRIA DO COURO. Guia Brasileiro do Couro. Rio Grande do Sul: ABQTIC, 1995. 86p. 
BARCELO, J.; POSCHENREIDER, C.; GUNSE, B. Effect of chromium (VI) on mineral element composition of bush beans. Journal of Plant Nutrition, v.8, p.211$218,1985$.

BARTLETT, R.J. \& JAMES, B.R. Behavior of chromium in soils: III. oxidation. Journal of Environmental Quality, v.8, n.1, p.31-35, 1979.

BARTLETT, R.J. \& JAMES, B.R. Mobility and bioavailability of chromium in soils. In: NRIAGU, J.O \& NIEBOER, E. (Ed.) Chromium in the Natural and Human Environments. New York: John Wiley \& Sons, Inc., 1988. cap 10, p.267-304.

BARTLETT, R.J. \& JAMES, B.R. Studying dried, stored soil samples-some pitfalls. Soil Science Society of American Journal, v.44, p.721-724, 1980.

BARTLETT, R.J. \& KIMBLE, J.M. Behavior of chromium in soils: I. trivalent forms. Journal of Environmental Quality, v.5, n.4, p.379-382, 1976a.

BARTLETT, R.J. \& KIMBLE, J.M. Behavior of chromium in soils: II. hexavalent forms. Journal of Environmental Quality, v.5, n.4, p.383-386, 1976 b. 
BEAUCHAMP, E.G.; REYNOLDS, W.D.; BRASCHE-VILLENEUVE, D.; KIRBY, K. Nitrogen mineralization kinetics with different soil pretreatments and cropping histories. Soil Science Society of of Americam Journal, v.50, p.1478-1483, 1986.

BLOOMFIELD, C.; PRUDEN, G. The behavior of $\mathrm{Cr}(\mathrm{VI})$ in soil under aerobic and anaerobic conditions. Environmental Pollution (Series A), v.23, p.103-114, 1980.

BOHN, H, Mc NEAL, B.L.; O'CONNOR, G.A. Salt-afected soils. In: Soil Chemistry.New York: Willey Interscience Publication, 1985. cap 9, p.234-261.

BREMNER, Y.M.; KEENEY, D.R. Determination and isotope ratio analysis of different forms of nitrogen in soils. III exchangeable ammonium, nitrate and nitrite by steam Destillation methods. Soil Science Society of American Proceedings, Madison, v.30, p.577-582, 1966.

BREMNER, J.M. Nitrogen total. In Bigham, J.M. Methods of soil analysis Part 3 Chemical methods. Wisconsin. Soil Science Society of America Journal, 1996. Cap.3, p.1085-1121.

BUERGE, I.J. \& HUG, S.J. Kinetics and pH dependence of chromium(VI) reduction by iron(II). Environmental Science and Technology, v.31, p.1426-1432, 1997. 
CAMARGO, F.A.O. Fracionamento e dinâmica do nitrogênio orgânico em solos do Rio Grande do Sul. Porto Alegre, 1996. 153p. Tese (Doutorado). Universidade Federal do Rio Grande do Sul

CAMARGO, O.A.; MONIZ, A.C.; JORGE, J.A.; VALADARES, J.M.A.S. Métodos de análise química, mineralógica e física de solos do Instituto Agronômico de Campinas. Campinas, Instituto Agronômico, 1986. 94p. (Boletim técnico, 106).

CARY, E.E.; ALLAWAY, W.H.; OLSON, O.E. Control of chromium concentration in food plants. 1. Absorpition and translocation of chromium by plants. Journal of Agricultural and Food Chemistry, v.25, n.2, p.300-304, 1977a.

CARY, E.E.; ALLAWAY, W.H.; OLSON, O.E. Control of chromium concentration in food plants. 2. Chemistry of chromium in soils and its availability to plants. Journal of Agricultural and Food Chemistry, v.25, n.2, p.305-309, 1977b.

CHANG, F.H.; BROADBENT, F.E. Influence of trace metals on some soil nitrogen transformation. Journal of Environmental Quality, v.11, n.1, p.1-4, 1982.

COALE, F.J.; EVANGELOU, V.P.; GROVE, J.H. Effects of saline-sodic soil chemistry on soybean mineral composition and stomatal resistance. Journal of Environmental Quality, v.13, n.4, p.635-639, 1984. 
COMPANHIA DE TECNOLGIA E SANEAMENTO AMBIENTAL. Compilação de padrões ambientais. São Paulo: CETESB, 6p., 1990.

DAR, G.H.; MISHRA, M.M.; Influence of cadmium on carbon and nitrogen mineralization in sewage sludge amended soils. Environmental Pollution, v.84, p.285-290, 1994.

DEANS, J.R.; MOLINA, J.A.E.; CLAPP, E.C. Models for predicting potentially mineralizable nitrogen and decomposition rate constants. Soil Science Society of Americam Journal, v.50, p.323-326, 1986.

DEPARTMENT of HEALTH and ENVIRONMENTAL CONTROL. Benificial use of wastewater biosolids - South Carolina guide on land application of wastewater sludge. South Carolina: DHEC, 1996. 50p.

DUBBIN, W.E. \& GOH, T.B. Sorptive capacity of montmorillonite for hidroxy-Cr polymers and the mode of $\mathrm{Cr}$ complexation. Clay Minerals, v.30, p.175-185, 1995.

DUDKA, S. \& CHLOPECKA, A. Effect of solid-phase speciation on metal mobility and phytoavailability in sludge-amended soil. Water, Air, and Soil Pollution, v.51, p.153-160, 1990. 
EARY, L.E. \& RAI, D. Chromate reduction by subsurface soils under acidic conditions. Soil Science Society Americam Journal, v.55, p.676-683, 1991.

EARY, L.E. \& RAI, D. Chromate removal from aqueous wastes by reduction with ferrous ion. Environmental Science and Technology, v.22, p.972-977, 1988.

EARY, L.E. \& RAI, D. Kinetics of chromium (III) oxidation to chromium (VI) by reaction with manganese dioxide. Environmental Science and Technology, v.21, p.1187-1193, 1987.

EQUIPE técnica do grupo MK (ETGMK). Aspestos ecológicos da produção de couros. Revista do Couro,volume, fasc., p.49-54, dezembro de 1996.

FENDORF, S.E. \& LI, G. Kinetics of chromate reduction by ferrous iron. Environmental Science and Technology, v.30, p.1614-1617, 1996.

FENDORF, S.E. \& ZASOSKI, R.J. Chromium (III) oxidation by $\delta$-MnO2. 1 . caracterization. Environmental Science and Technology, v.26, p.79-85, 1992.

FENDORF, S.E. Surface reactions of chromium in soils and waters. Geoderma, v.67, p.55-71, 1995. 
FENDORF, S.E.; FENDORF, M.; SPARKS, D.L.; GRONSKY, R. Inhibitory mechanisms of $\mathrm{Cr}(\mathrm{III})$ oxidation by $\delta-\mathrm{MnO}_{2}$. Journal of Colloid and Interface Science, v.153, p.37-54, 1992.

FENDORF, S.E.; LAMBLE, G.M.; STAPLETON, M.G.; KELLEY, J.M.; SPARKS, D.L. Mechanisms of chromium(III) sorption on silica. 1. Cr(III) surface structure derived by extended X-ray absorption fine structure spectroscopy. Environmental Science and Technology, v.28, p.284-289, 1994.

FIGLIOLIA, A.; BENEDETTI, A.; DELL'ABATE, M.T.; IZZA,C.; INDIATI, R. Potential chromium bio-availability by lactuca sativa grown on two soils amended with tannery leather residues. Fresenius Environmental Bulletin, v.1, p.406-410, 1992.

FURLANI, A.M.C.; FURLANI, P.R.; BATAGLIA, O.C. et al. Composição mineral de diversas hortaliças. Bragantia, v.37, n.5, p.33-44, 1978.

GAMA-RODRIGUES，E.F. da; GAMA-RODRIGUES，A.C. da; BARROS， N.F. Biomassa microbiana de carbono e de nitrogênio de solos sob diferentes coberturas florestais. Revista Brasileira de Ciência do Solo. v.21, n.3, p.361-365, 1997.

GARAU, M.A.; FELIPÓ, M.T.; VILLA, C.R. Nitrogen mineralization of sewage sludges in soils. Journal of Environmental Quality, v.15. n.3, p.225-228, 1986. 
GRIFFIN, R.A.; AU, A.K.; FROST, R.R. Effect of $\mathrm{pH}$ on adsorption of chromium from landfill leachate by clay minerals. Journal of Environmental Science and Health A, v.12, n.8, p.431-449, 1977.

GRIFFIN, G.F.; LAINE, A.F. Nitrogen mineralization in soils previously amended with organic wastes. Agronomy Journal, v.75, p.124-129, jan.-fev., 1983.

GROVE, J.H. \& ELLIS, B.G. Extractable iron and manganese as related to soil $\mathrm{pH}$ and applied chromium. Soil Science Society Americam Journal, v.40, p.243-246, 1980a.

GRUBINGER, V.P.; GUTENMANN, W.H.; DOSS, G.J., RUTZKE, M., LISK, D.J. Chromium in swiss chard grown on soil amended with tannery meal fertilizer. Chemosphere, v.28, n.4, p.717-720, 1994.

GUTIERRES, M. Tecnologia da produção do couro. In: CONGRESSO LATINOAMERICANO DE ESTUDANTES DE ENGENHARIA QUÍMICA, 1., Porto Alegre, 1996. Anais. Rio Grande do Sul: UFRGS, 30p., 1996.

HEMPHILL,Jr., D.D.; VOLK, V.V.; SHEETS, P.J.; WICKLIFF,C. Lettuce and broccoli response and soil properties resulting from tannery waste applications. Journal of Environmental Quality, v.14.n.2, p.159-163, 1985. 
HSIEH, Y.P.; DOUGLAS, L.A.; MOTTO, H.L. Modeling sewage sludge decomposition in soil: II. nitrogen transformations. Journal of Environmental Quality, v.10. n.1, p.59-64, 1981.

HUFFMAN, Jr, E.W.D. \& ALLAWAY,W.H. Chromium in plants: distribuition in tissues, organelles and extracts and availability of bean leaf $\mathrm{Cr}$ to animals. Journal of Agricultural and Food Chemistry, v.21, n.6, p.982-986, 1973.

JAMES, B.R \& BARTLETT, R.J. Behavior of chromium in soils: V. fate of organically complexed $\mathrm{Cr}(\mathrm{III})$ adicionado ao solo. Journal of Environmental Quality, v.12, n.2, p.169-172, 1983a.

JAMES, B.R \& BARTLETT, R.J. Behavior of chromium in soils: VI. interactions between oxidation-reduction ans organic complexation. Journal of Environmental Quality, v.12, n., p.173-176, 1983 b.

JAMES, B.R \& BARTLETT, R.J. Behavior of chromium in soils: VII. adsorption and reduction of hexavalent forms. Journal of Environmental Quality, v.12, n., p.177$181,1983 \mathrm{c}$.

JAMES, B.R. \& BARTLETT, R.J. Plant-soil interactions of chromium. Journal of Environmental Quality, v.13, n.1, p.67-70, 1984. 
JAMES, B.R.; BARTLETT, R.J. Nitrification in soil suspensions treated with chromium (III, VI) salts or tannery wastes. Soil Biological Biochemistry, v.16, n.3, p.293-295, 1984.

JOHNSON, C.A. \& XYLA, A.G. The oxidation of chromium(III) to chromium(VI) on the surface of manganite $(\gamma-\mathrm{MnOOH})$. Geochimica et Cosmochimica Acta, v.55, p.2861-2866, 1991.

KELLING, K.A.; WALSH, L.M.; KEENEY, D.R.; RYAN,J.A.;PETERSON, A.E. A field study of the agricultural use of sewage sludge: II. effect on soil $\mathrm{N}$ and $\mathrm{P}$. Journal of Environmental Quality, v.6. n.4, p.345-352, 1977.

KOZUH, N.; STUPAR, J.; MILACIC, R.; GORENC, B. Optimization of extraction of total water-soluble chromium and chromium(VI) in various soils. Intern. J. Environ. Anal. Chem., v.56, p.207-217, 1994.

LAHOUTI, M.; PETERSON, P.J. Chromium accumulation and distribution in crop plants. Journal of Science and Food and Agriculture, v.30, p.136-142, 1979.

LIANG, C.N.; TABATABAI, M.A. Effects of trace elements on nitrification in soils. Journal of Environmental Quality, v.7, n.2, p.291-293, 1978. 
LIANG, C.N.; TABATABAI, M.A. Effects of trace elements on nitrogen mineralisation in soils. Environmental Pollution, v.12, p.141-147, 1977.

LINDEMANN, W.C.; CARDENAS, M. Nitrogen mineralization potential and nitrogen transformations of sludge-amended soil. Soil Science Society Americam Journal, v.48, p.1072-1077, 1984.

LOSI, M.E.; AMRHEIN, C.; FRANKENBERGER, Jr., W.T. Factors affecting chemical and biological reduction of hexavalent chromium in soil. Environmental Toxicology and Chemistry, v.13, n.11, p.1727-1735, 1994.

MAAS, E.V. Salt Tolerance of Plants. In: CHRISTIE, B.R (Ed.) Handbook of plant science in agriculture. Flórida: CRC Press Boca Raton, 1990.

MAcGRATH, S.P. The uptake and translocation of tri and hexa-valent chromium and effects on the growth of oat in flowing nutrient solution and in soil. New Phitol., v.92, p.381-389, 1982.

MAcGRATH, S.P.; SMITH, S. Chromium and nickel. In: ALLOWAY, B.J. (Ed.) Heavy metals in soils. New York: John Wiley \& Sons, Inc., 1990. cap 7, p.125-150. 
MAGDOFF, F.R.; AMADON, J.F. Nitrogen availability from sewage sludge. Journal of Environmental Quality, v.9. n.3, p.451-455, 1980.

MERTZ, W. Chromium occurrence and function in biological systems. Physiological Reviews, v.49, n.2, p.163-239, abr. 1969.

MESUERE, K.; FISH, W. Chromate and oxalate adsorption on goethite. 1. calibration of surface complexation models. Environmental Science and Technology, v.26, p.2357-2364, 1992a.

MESUERE, K.; FISH, W. Chromate and oxalate adsorption on goethite. 2. Surface complexation modeling of competitive adsorption. Environmental Science and Technology, v.26, p.2365-2370, $1992 b$.

MOLINA, J.A.E.; CLAPP, C.E.; LARSON, W.E. Potentially mineralizable nitrogen in soil: the simple exponential model does not apply for the first 12 weeks of incubation. Soil Science Society of Americam Journal, v.44, p.442-443, 1980.

MORTVEDT, J.J. \& GIORDANO, P.M. Response of corn to zinc and chromium in municipal wastes applied to soil. Journal of Environmental Quality, v.4, n.2, p.170-174, 1975. 
NRIAGU, J.O. Historical perspectives. In: NRIAGU, J.O \& NIEBOER, E. (Ed.) Chromium in the natural and human environments. New York: John Wiley \& Sons, Inc., 1988a. cap 1, p.1-19.

NRIAGU, J.O. Production and uses of chromium. In: NRIAGU, J.O \& NIEBOER, E. (Ed.) Chromium in the natural and human Environments. New York: John Wiley \& Sons, Inc., 1988b. cap 3, p.81-103.

OLIVEIRA, J.B.; MENK, J.R.; ROTTA, C.L. Levantamento pedológico semidetalhado dos solos do Estado de São Paulo. Rio de Janeiro, IBGE, 1979. 169p. (Série Recursos Naturais e Meio Ambiente, 5).

OLIVEIRA, S.A. Avaliação da mineralização e disponibilidade de nitrogênio para o trigo (Triticum aestivum L.) em solos do Distrito Federal. Piracicaba, 1987. 128p. Tese (Doutorado) - Escola Superior de Agricultura "Luiz de Queiroz" da Universidade de São Paulo.

OTABBONG, E. Chemistry of $\mathrm{Cr}$ in some swedish soil. V. interaction between $\mathrm{CrO} 3$ and $\mathrm{Si}(\mathrm{OH}) 4$ and its impact on $\mathrm{Cr}$ toxicity and elemental contents in ryegrass (Lolium perenne). Plant and Soil, v.123, p.89-93, 1990.

PALMER, C.D.; WITTBRODT, P.R. Processes affecting the remediation of chromiumcontaminated sites. Environmental Health Perspectives, v.92, p.25-40, 1991. 
PAPADOPOULOS, I. Effects of residual soil salinity resulting from irrigation with sulphate waters on lettuce. Plant and Soil, v.97, p.171-177, 1987.

PARKER, C.F.; SOMMERS, L.E. Mineralization of nitrogen in sewage sludges. Journal of Environmental Quality, v.12. n.1, p.150-156, 1983.

PENDIAS, A.K.; PENDIAS, H. Trace elements in plants. In: Trace elements in soil and plants. New York: CRC Press Inc., 1984. cap 5, p.51-68.

RAI, D.; EARY, L.E.; ZACHARA, J.M. Environmental chemistry of chromium. The science of the total environment, v.86, p.15-23, 1989.

RAIJ, B. van; QUAGGIO, J.A.; CANTARELLA, H.; FERREIRA, M.A.; LOPES, A.S.; BATAGLIA, O.C. Análise química do solo para fins de fertilidade. Campinas, Fundação Cargill, 1987, 169p.

RAMACHANDRAN, V.; D'SOUZA, T.J.; MISTRY, K.B. Uptake and tranport of chromium in plants. Journal of Nuclear Agric. Biol., v.9, p.126-128, 1980.

RENGASAMY, P. \& OADES, J.M. Interaction of monomeric and polymeric species of metal ions with clay surfaces. III* aluminium(III) and chromium(III). Australian Journal of Soil Research, v.16, p.53-66, 1978. 
ROSS, D.S.; SJOGREN, R.E.; BARTLETT, R.J. Behavior of chromium in soils: IV. toxicity to microorganisms. Journal of Environmental Quality, v.10, n.2, p.145$148,1981$.

ROTHER, J.A.; MILLBANK, J.W.; THORNTON, I. Effects of heavy-metal additions on ammonification and nitrification in soils contaminated with cadmium, lead and zinc. Plant and Soil, v.69, p.239-258, 1982.

SELBACH, P.A.; TEDESCO, M.J.; GIANELLO, C.; CAVALET, L.E. Descarte e biodegradação de lodos de curtume no solo. Revista do Couro, v.81, p.83-94, 1991.

SHEPPARD, M.I.; SHEPPARD, S.C.; THIBAULT, D.H. Uptake by plants and migration of uranium and chromium in field lysimeters. Journal of Environmental Quality, v.13, n.3, p.357-361, 1984.

SHEWRY, P.R. \& PETERSON, P.J. The uptake and transport of chromium by barley seedlings (Hordeum vulgare L.). Journal of Experimental Botany, v.25, n.87, p.785-797, agosto 1974.

SKEFFINGTON, R.A.; SHEWRY, P.R., PETERSON, P.J. Chromium uptake and transport in barley seedlings (Hordeum vulgare L.). Planta, v.132, p.209-214, 1976. 
SMILDE, K.W. Heavy-metal accumulation in crops grown on sewage sludge amended with metal salts. Plant and Soil, v.62, p.3-14, 1981.

SMITH, J.L.; SCHNOBEL, B.L.; Mcneal, B.L.; CAMPBELL, G.S. Potential errors in the first-order model for estimating soil nitrogen mineralization potentials. Soil Science Society of Americam Journal, v.44, p.996-1000, 1980.

SOUZA, A.; FOLDA JR., C.; CARMO, D.; RODRIGUES, J. O. Introdução ao tratamento de efluentes industriais. Módulo II - orientações básicas para tratamento de efluentes de curtume. Centro Tecnológico do Couro, 40p., 1991.

STANDARD METHODS FOR THE EXAMINATION OF WATER AND WASTEWATER. Inorganic nonmetalic constituents phosphorus-automated ascorbic acid reduction method. Washington, DC: American Public Health Association, 1995. cap.4, p.106-115.

STANDFORD, G.; SMITH, S.J. Nitrogen mineralization potentials of soils. Soil Science Society Americam Journal, v.36, p.465-472, 1972.

STOMBERG, A.L.; HEMPHILL,Jr., D.D.; VOLK, V.V. Yield and elemental concentration of sweet corn grown on tannery waste-amended soil. Journal of Environmental Quality, v.13. n.1, p.162-166, 1984. 
STRAUS, E.L.; SILVA, M.L de A. Resíduos de Curtume. CETESB, São Paulo, 86p., 1980.

SYKES, R.L.; CORNING, D.R.; EARL, N.J. The effect of soil-chromium III on the growth and chromium absorption of various plants. Journal of American Lether Chemists Association, v.76, p.102-125, 1981.

TERRY, R.E.; NELSON, D.W.; SOMMERS, L.E. Nitrogen transformation in sewage sludge-amended soils as affected by soil environmental factors. Soil Science Society Americam Journal, v.45, p.506-513, 1981.

TREBIEN, D.O.P. Influência dos teores de matéria orgânica, óxidos de manganês facilmente reduzíveis e umidade na oxidação de crômio no solo. Porto Alegre, 1994. 81p. Tese (Doutorado) - Faculdade de Agronomia, Universidade Federal do Rio Grande do Sul.

UNITED STATES ENVIRONMENTAL PROTECTION AGENCY. Harzadous waste land treatment. U.S.E.P.A. Draft, 974p., 1980.

UNITED STATES ENVIRONMENTAL PROTECTION AGENCY. Metallic analytes Method 3050 acid digestion of sediments, sludges an soils. In: Test methods for evaluating solid wastes. Washington : U.S.E.P.A. 1986. Capítulo 3. 6p., 1980. 
WALLACE, A.; SOUFI, M.S.; ALEXANDER, G.V.; CHA, J.W. Comparison of the effects of high levels of DTPA and EDDHA on microelement uptake in bush beans. Commun. in Soil Science and Plant Analysis, v.7, n.1, p.111-116, 1976 a.

WALLACE, A.; SOUFI, S.M.; CHA, J.W.; ROMNEY, E.M. Some effects of chromium toxicity on bush bean plants grown in soil. Plant and Soil, v.44, p.471-473, 1976b.

WICKLIFF, C.; VOLK, V.V.; TINGEY, D.T.; GRIFFIS, W.L.; TRUNK, M.Y.; WITHEROW, J.L. Reactions of chrome tannery sludge with organic and mineral soils. Water, Air, and Soil Pollution, v.17, p.61-74, 1982.

WISEMAN, J.T.; ZIBILSKE, L.M. Effects of sludge application sequence on carbon and nitrogen mineralization in soil. Journal of Environmental Quality, v.17. n.2, p.334-339, 1988.

WITTBRODT, P.R.; PALMER, C.D. Reduction of Cr(VI) in the presence of excess soil fulvic acid. Environmental Science and Technology, v.29, p.255-263, 1995.

WORLD HEALTH ORGANIZATION. Chromium environmental health criteria. Genebra, 1988. v.61, 197p. 
ZACHARA, J.M.; AINSWORTH, C.C.; COWAN, C.E.; RESCH, C.T. Adsorpition of chromate by subsurface soil horizons. Soil Science Society Americam Journal, v.53, p.418-428, 1989. 